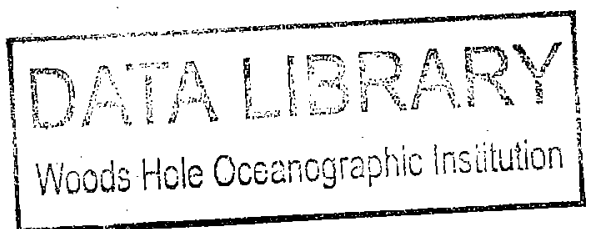

WHOI-94-07

IfM-Kiel 243

WOODS HOLE OCEANOGRAPHIC INSTITUTION

C. 2

\title{
Technical
}

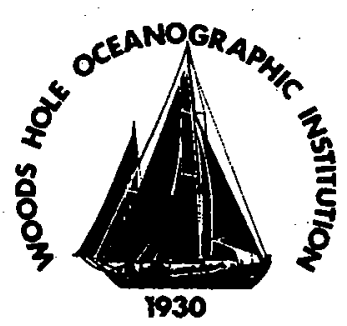

BERICHTE

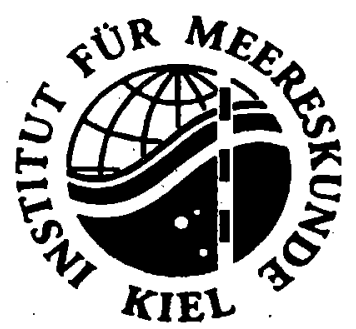

aus dem

INSTITUT FÜR MEERSKUNDE

an der

CHRISTIAN-ALBRECHTS-UNIVERSITÄT - KIEL

\section{A moored array along the southern boundary of the Brazil Basin for the Deep Basin Experiment - Report on a joint experiment 1991-1992.}

by

\author{
Susan Tarbell' Ralf Meyer', \\ Nelson Hogg ${ }^{1}$, and Walter Zenk ${ }^{2}$
}

\begin{abstract}
May 1994
Funding was provided by the Deutsche Forschungsgemeinschaft (Si 111/38-1, Si 111/39-1) the Bundesministerium für Forschung und Technologie (03F0535A, 03F0050D) and the National Science Foundation under Grant OCE-9004396.
\end{abstract}

Approved for public release; distribution unlimited.

'Woods Hole

Oceanographic Institution

Woods Hole, Massachusetts 02543

United States of America
2Institut für Meereskunde and der Universität Kiel Düsternbrooker Weg 20 24105 Kiel, Germany 


\title{
WHOI-94-07
}

A moored array along the southern boundary of the Brazil Basin for the Deep Basin Experiment-

Report on a joint experiment 1991-1992.

\author{
by \\ Susan Tarbell, Ralf Meyer, Nelson Hogg, and Walter Zenk \\ Woods Hole Oceanographic Institution \\ Woods Hole, Massachusetts 02543
}

February 1994

Technical Report

Funding was provided by Deutsche Forschungsgemeinschaft ( $\mathrm{Si}$ 111/38-1/ Si 111/39-1)

Bundesministerium für Forschung und Technologie (03F0535A, 03F0050D, F0121A) and the National Science Foundation Grant OCE-9004396.

Reproduction in whole or in part is permitted for any purpose of the United States Government. This report should be cited as Woods Hole Oceanog. Inst. Tech. Rept., WHOI-94-07.

Approved for public release; distribution unlimited.

\author{
Approved for Distribution:
}

Department of Physical Oceanography 



\section{Table of Contents}

List of Tables .......................... iv

List of Figures ..........................

1. Introduction $\ldots \ldots \ldots \ldots \ldots \ldots$

2. Hydrographic Background ........................ 3

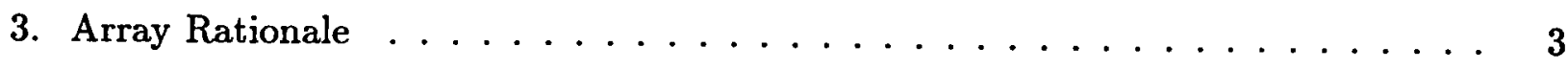

4. Moorings .............................. 8

5. Pressure Sensor Performance . . . . . . . . . . . . . . . . . . 12

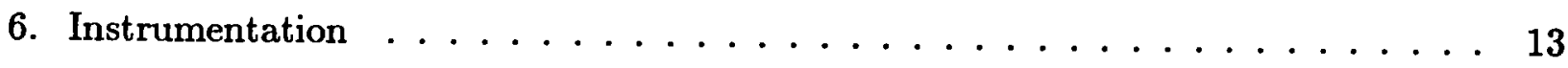

6.1 Aanderaa Current Meters (RCMs) ................. 13

6.2 Acoustic Doppler Current Profilers (ADCPs) . . . . . . . . . . 15

6.3 Vector Averaging Current Meters (VACMs) . . . . . . . . . . 15

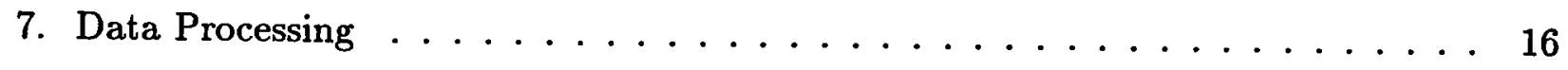

7.1 Aanderaa - IfM-Kiel . . . . . . . . . . . . . . 16

7.2 ADCP - IfM-Kiel . . . . . . . . . . . . . . . 19

$7.3 \mathrm{VACM}-\mathrm{WHOI} \ldots \ldots \ldots \ldots \ldots$ 


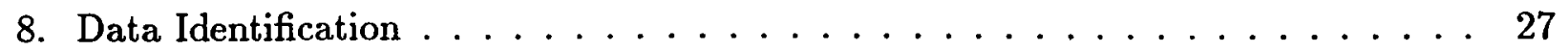

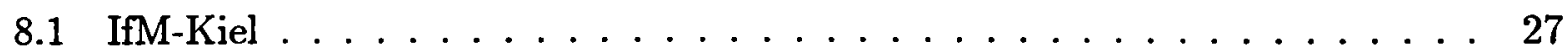

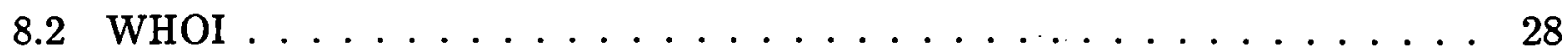

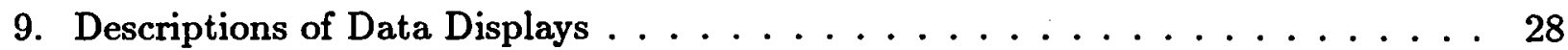

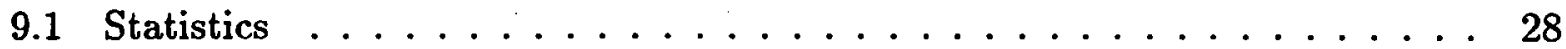

9.2 Progressive Vector Plots $\ldots \ldots \ldots \ldots \ldots \ldots$

9.3 Variables versus Time $\ldots \ldots \ldots \ldots \ldots \ldots$

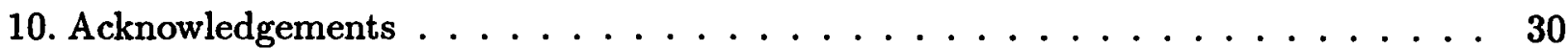

11. References . . . . . . . . . . . . . . . . . . 31

Plots by Mooring - BW $333 \ldots \ldots \ldots \ldots \ldots \ldots$

Mooring BM $334 \ldots \ldots \ldots \ldots \ldots \ldots \ldots \ldots \ldots \ldots \ldots$

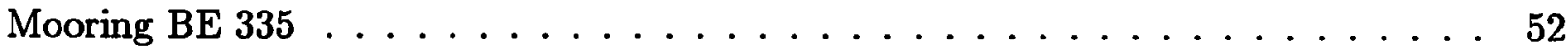

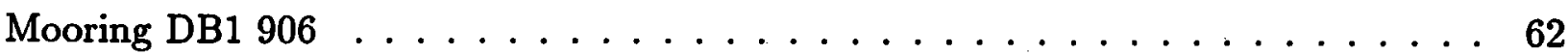

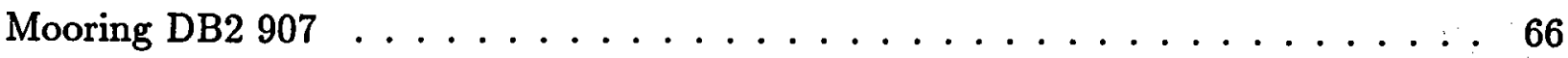

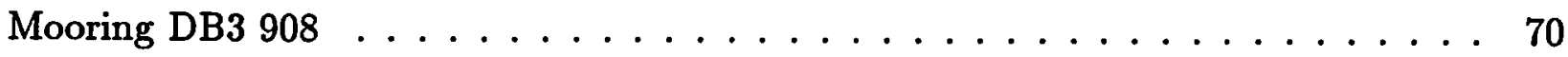

Mooring DB4 $909 \ldots \ldots \ldots \ldots \ldots \ldots \ldots \ldots \ldots \ldots \ldots$

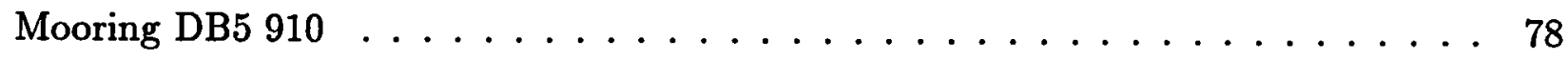

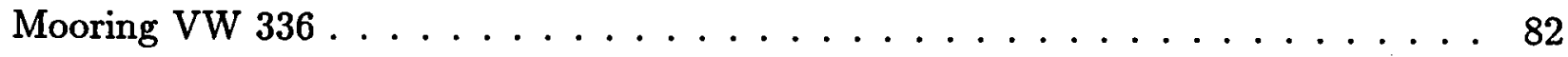


Mooring VE $338 \ldots \ldots \ldots \ldots \ldots$

Mooring DB6 $912 \ldots \ldots \ldots \ldots \ldots$

Mooring DBK $343 \ldots \ldots \ldots \ldots \ldots \ldots \ldots$ 


\section{List of Tables}

1 Moorings with Corresponding CTD Sections . . . . . . . . . . . . 5

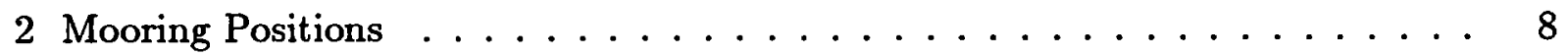

3 Deep Basin Moorings, Southern Rim of Brazil Basin . . . . . . . . . . . 8

4 Pressure Sensor Data . . . . . . . . . . . . . . . . . 13

5 Differences between Aanderaa Current Meter Types RCM5 and RCM8 . . . . 14

6 Number of Data Cycles Changed . . . . . . . . . . . . . . . 18

7 Selection of ADCP Parameters . . . . . . . . . . . . . . . 19

8a Deep Basin Data Quality-WHOI . . . . . . . . . . . . . 21

8b Deep Basin Data Quality-IfM-Kiel . . . . . . . . . . . . . . . 24

9 Description of Column Headings for Statistical Table . . . . . . . . . . . . 29

10 Statistical Values from Southern Boundary of the Brazil Basin . . . . . . . . 34 


\section{List of Figures}

1 Mooring array on the Rio Grande Ridge $\ldots \ldots \ldots \ldots$

2 Vertical distributions of potential temperature . . . . . . . . 4

3 Distribution of current meters . . . . . . . . . . . . 6

4 Representative mooring design for IfM-Kiel $\ldots \ldots \ldots \ldots \ldots$

$5 \quad$ Representative mooring design for WHOI $\ldots \ldots \ldots \ldots \ldots$ 


\section{Introduction}

The Deep Basin Experiment (DBE) is an international effort with the principal objective of improving our knowledge of the subthermocline circulation, both in a descriptive and dynamical sense. The DBE is designated as an official World Ocean Circulation Experiment (WOCE) program under Core Project 3. Its plan and implementation are described in the document "Toward a Deep Basin Experiment" (WOCE, 1990). For both logistic and scientific reasons the DBE field work is focussed on the Brazil Basin, a region to the west of the Mid-Atlantic Ridge stretching from the Ceara Rise near the equator in the north to the Santos Plateau-Rio Grande Rise system near $30^{\circ} \mathrm{S}$. This report is concerned with the joint German/American [Institut für Meereskunde of the University of Kiel (IfM-Kiel) and the Woods Hole Oceanographic Institution (WHOI)] moored array situated along the southern boundary of the Brazil Basin (Figure 1a and b). It was installed in early 1991 to measure the inflow and outflow along the southern boundary of the Brazil Basin. Complimentary arrays have been set in the Hunter Channel (see below), out from the western boundary near $19^{\circ} \mathrm{S}$, across a sill at the equator near $45^{\circ} \mathrm{W}$ and in the Romanche and Chain fracture zones (Mercier et al. 1994 and Speer et al., submitted 1994.)

This technical report describes the data from the German/American current meter array that spanned the western Rio Grande Ridge between the continental slope and the eastern flanks of the Vema Channel (Figure 1a and b), which plays an important role in controlling the abyssal circulation of the western South Atlantic. Further current and CTD data from the Vema Channel may be found in the report by Levy (1983).

Some of the instruments that were recovered from the first DBE array were refurbished and reset in the Hunter Channel, a suspected conduit for further exchange between 
(a)

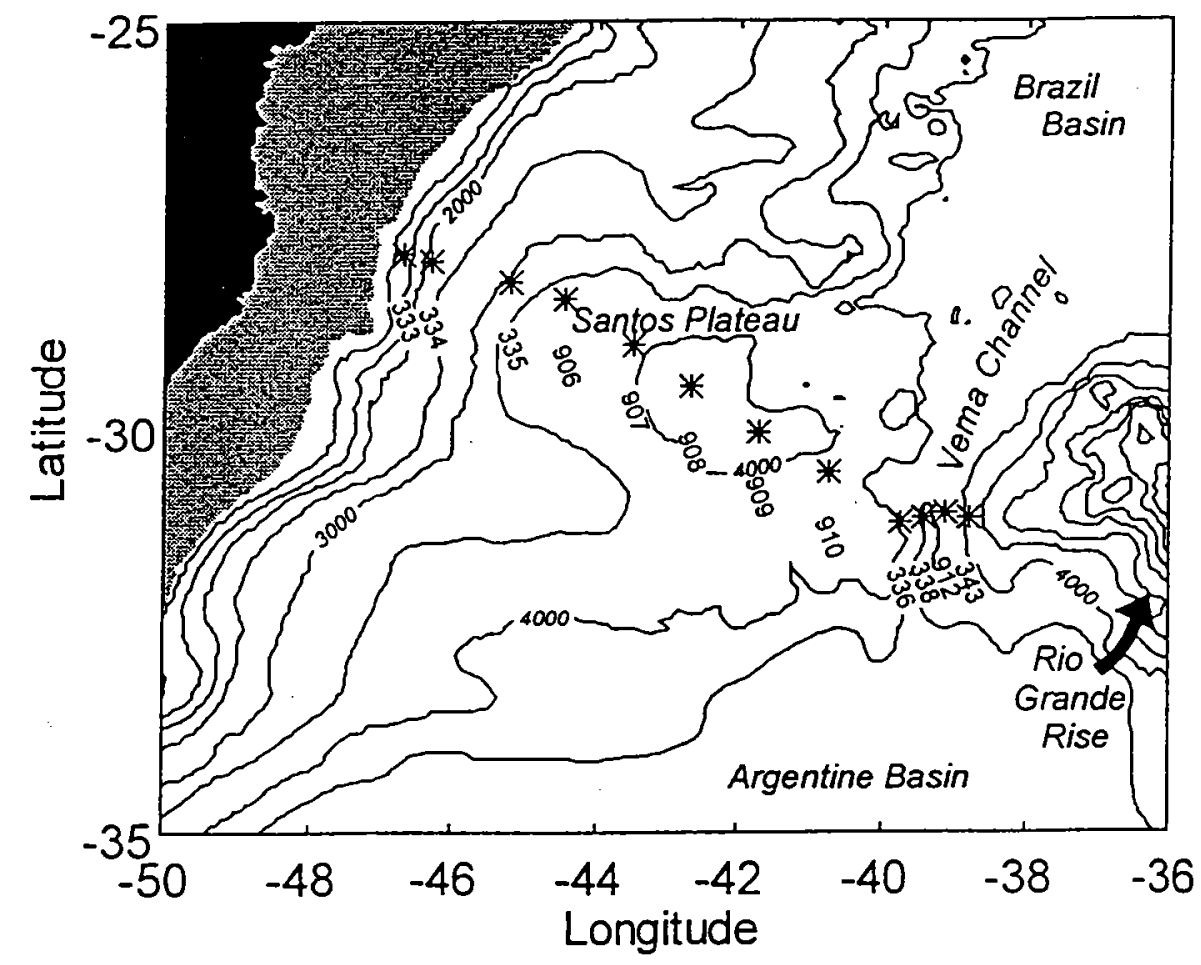

(b)

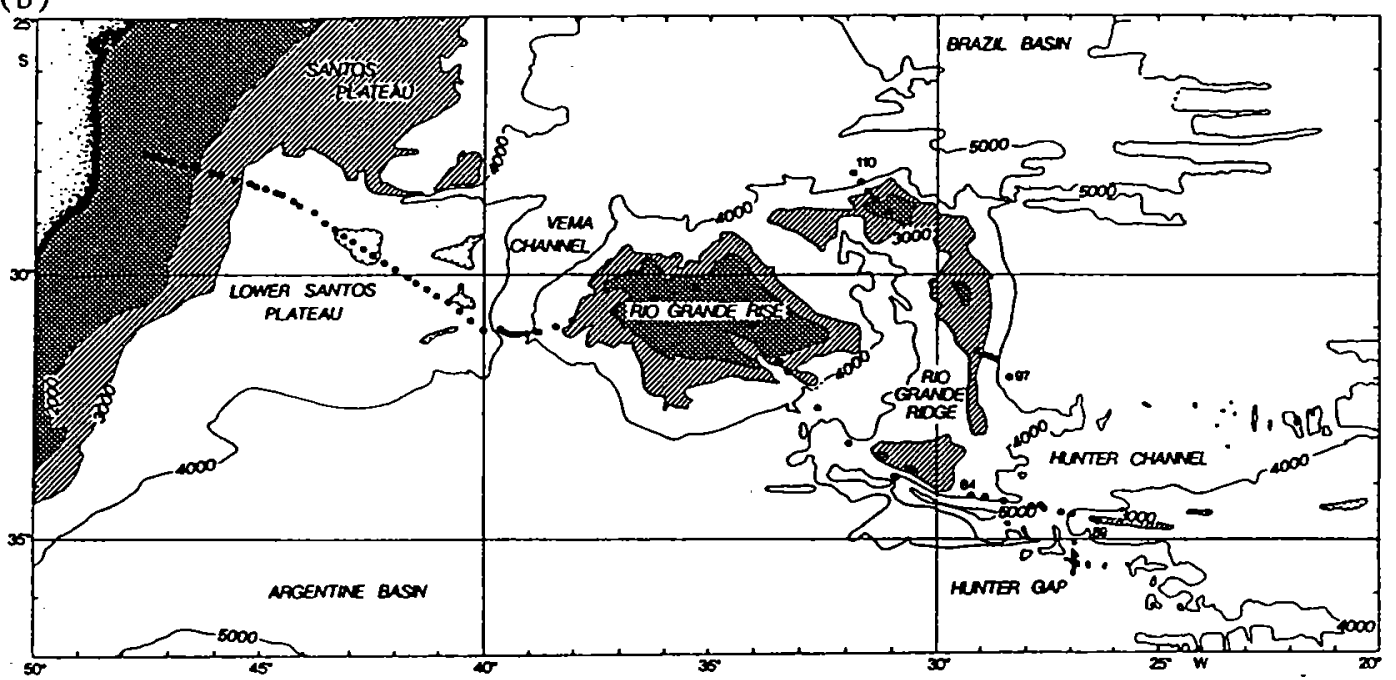

Figure 1: (a) Mooring array on the Rio Grande Ridge. Instruments were deployed during Meteor Cruise 15, January 1991, and recovered during Cruise 22, December 1992. One of the 13 moorings was lost completely (VM/337). The uppermost of two instruments was recovered from DB5/910 in October 1994 from the RV Ewing, by dragging for the mooring. (b) Bottom topography of the Rio Grande Rise according to Gherkis et al. (1989). The Rio Grande Rise separates the Argentine Basin to the south from the Brazil Basin. Meteor Cruise 15 included a CTD section (stations 1-89) between the shelf off Brazil and the Hunter Channel. Additional short sections were taken from the eastern (stations 97-101) and northern (stations 107-110) sides of the Rio Grande Ridge. (Speer and Zenk, 1993, with permission of the American Meteorological Society.) 
the Argentine Basin and the Brazil Basin. A later report will summarize these data after recoverey in May 1994.

\section{Hydrographic Background}

Before we consider current meter locations and depths, we will briefly review the hydrographic setting of our array between the Brazilian Slope and the Rio Grande Rise (Figure 2).

Thermocline waters in the west are characterized by the warm, southward flowing Brazil Current and the near-surface Salinity Maximum Water in the subtropics. The subtropical inner circulation is confined to the east by the Brazil Current Front about halfway between the shelf and the Rio Grande Rise. The depth interval of $800-1100 \mathrm{~m}$, i.e. the region beneath the South Atlantic Central Water (SACW), is occupied by the Antarctic Intermediate Water (AAIW) with its local minimum in the salinity versus depth profile ( $\mathrm{S} \leq 34.4 \mathrm{PSU})$ and maximum in oxygen $\left(\mathrm{O}_{2} \geq 5.2 \mathrm{ml} / \mathrm{l}\right)$. A second, deeper oxygen maximum is characteristic of the North Atlantic Deep Water (NADW) carrying salinities $\mathrm{S} \geq 34.8$ at depths between 1800-3200m. Admixtures of lower Circumpolar and Weddell Sea Deep Waters represent the Antarctic Bottom Water (AABW) of the region typically situated below $3200 \mathrm{~m}$ with potential temperatures lower than $2^{\circ} \mathrm{C}$.

\section{Array Rationale}

Instrument distribution across the Rio Grande section was chosen to be in accord with the first three objectives of the DBE: 


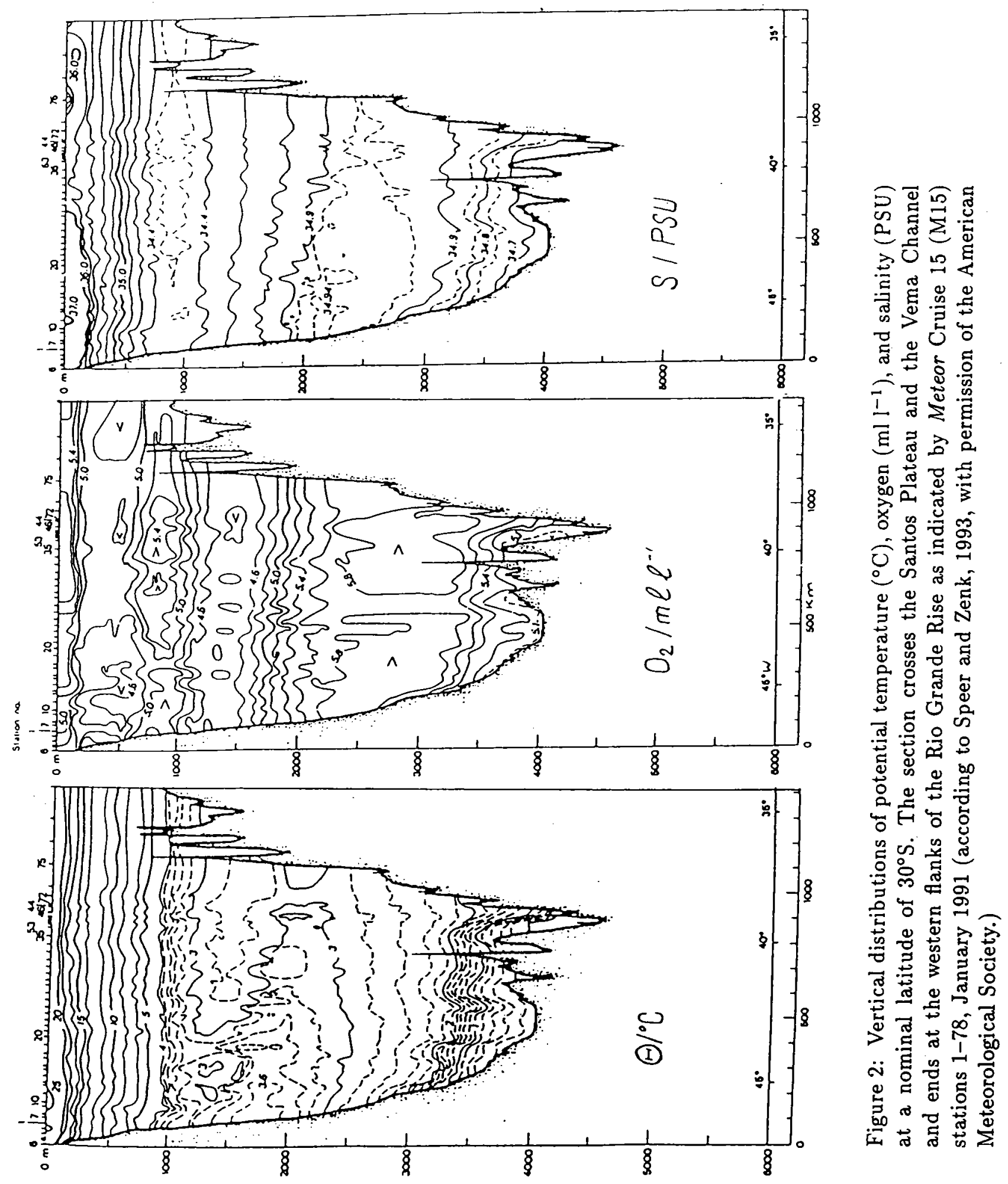


1. To observe and quantify the deep circulation, including the deep boundary currents, within the Brazil Basin. (For this array the DBE objective was extended into the thermocline.)

1a. To observe and quantify spatial and temporal changes of the Brazil Current and its recirculation on scales up to one year;

2. To distinguish between boundary and interior mixing processes;

3. To understand the means by which passages affect the flow of water through them.

WHOI moorings DB1 through DB5 (Deep Basin) were intended to monitor the transport of AAIW, NADW and AABW (Figure 3).

IfM-Kiel moorings BW/333 (Brazil Current West), BM/334 (Middle) and BE/335 (East) were tailored to meet the additional DBE objective, in particular, two upwardlooking Acoustic Doppler Current Profilers (ADCPs) were used to measure the top part of the water column.

The small scale of the Vema Sill (Zenk et al., 1993b) required a highly resolved array consisting of mooring VW on the western flanks, VE near the sill, and two moorings DB6 and DBK on the eastern terrace. Mooring VM (Vema Middle) in the central Vema Channel was lost.

Due to resource limitations not all moorings could cover the whole water column. However, we aimed at a consistent and, where possible, equidistant coverage of the NADW and $\mathrm{AABW}(2500 \mathrm{~m}, 3000 \mathrm{~m}$ and near bottom). Figures 1 and 3 reveal further instruments on the slope in the upper CPDW, i.e. between AAIW and NADW $(1400 \mathrm{~m})$, in the AAIW itself $(900 \mathrm{~m})$ as well as the SACW $(200 \mathrm{~m}, 500 \mathrm{~m})$.

Table 1 gives the correspondence of mooring positions and the closest CTD stations during launch (M15) and recovery (M22) cruises. Complete station inventories are compiled in the cruise reports by Siedler and Zenk (1992) and Siedler et al. (1993). 


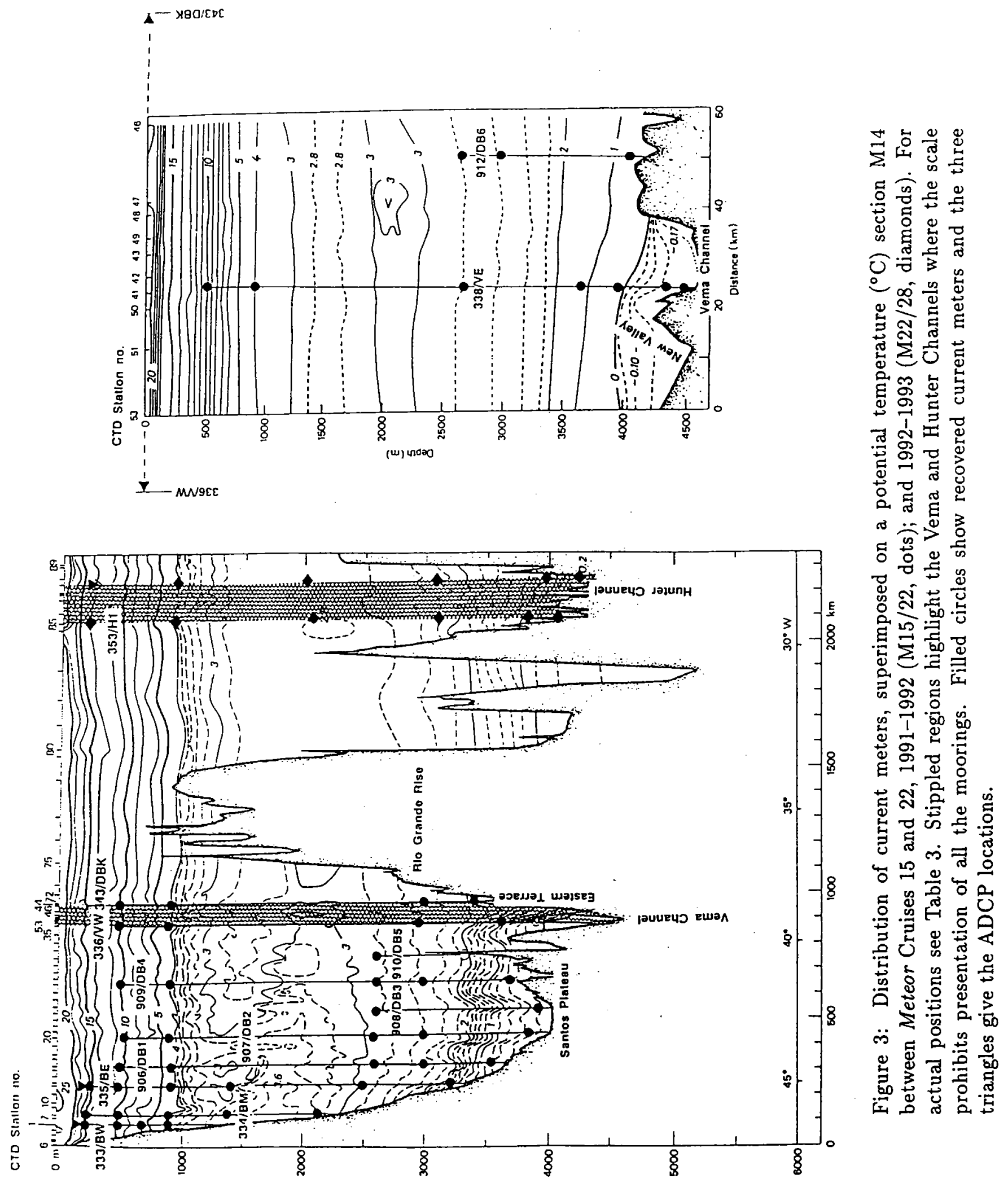


Table 1: Moorings with Corresponding CTD Sections During Launch (M15) and Recovery (M22) Cruises with FS Meteor.

\begin{tabular}{|c|c|c|c|c|c|c|c|c|c|c|}
\hline \multicolumn{2}{|c|}{ Mooring } & \multicolumn{5}{|c|}{$\begin{array}{c}\text { M15 } \\
\text { January } 1991\end{array}$} & \multicolumn{4}{|c|}{$\begin{array}{c}\text { M22 } \\
\text { December } 1992\end{array}$} \\
\hline \multirow[t]{2}{*}{ ID } & \multirow[t]{2}{*}{$\#$} & \multicolumn{3}{|c|}{ Nearest CTD } & \multirow{2}{*}{$\begin{array}{c}\text { Ship } \\
\text { Station } \\
\#\end{array}$} & \multirow{2}{*}{$\begin{array}{l}\text { Estim. } \\
\text { Depth } \\
\text { (m) }\end{array}$} & \multirow{2}{*}{$\begin{array}{c}\text { Ship } \\
\text { Station } \\
\#\end{array}$} & \multicolumn{3}{|c|}{ Nearest CTD } \\
\hline & & $\begin{array}{c}\text { Station } \\
\#\end{array}$ & $\begin{array}{l}\text { Profile } \\
\quad \#\end{array}$ & $\begin{array}{l}\text { Depth } \\
(\mathrm{m})\end{array}$ & & & & $\begin{array}{c}\text { Station } \\
\#\end{array}$ & $\begin{array}{l}\text { Profile } \\
\quad \#\end{array}$ & $\begin{array}{l}\text { Depth } \\
(\mathrm{m})\end{array}$ \\
\hline $\begin{array}{l}\text { Conti } \\
\text { Slope }\end{array}$ & ental & & & & & & & & & \\
\hline $\mathrm{BW}$ & 333 & 1 & 1 & $(2178)$ & 1 & 1179 & 558 & 556 & 14 & 1354 \\
\hline $\mathrm{BM}$ & 334 & 8 & 8 & 2248 & 8 & 2187 & 557 & 555 & 13 & (1901) \\
\hline $\begin{array}{l}\text { BE } \\
\text { Santo } \\
\text { Plate }\end{array}$ & 335 & 12 & 12 & 3273 & 12 & 3258 & 550 & 549 & 8 & 3208 \\
\hline DB1 & 906 & 16 & 16 & 3634 & 16 & $3632^{\dagger}$ & 575 & 575 & 31 & 3620 \\
\hline DB2 & 907 & 20 & 20 & 3922 & 20 & $3950^{\dagger}$ & 576 & 576 & 32 & 3919 \\
\hline DB3 & 908 & 24 & 24 & 4022 & 24 & $4019^{\dagger}$ & 577 & 577 & 33 & 4013 \\
\hline DB4 & 909 & 28 & 28 & 3782 & 28 & 3814 & 579 & 579 & 35 & (3913) \\
\hline $\begin{array}{l}\text { DB5 } \\
\text { Vema } \\
\text { Chan }\end{array}$ & 910 & 32 & 32 & 3736 & 32 & 3721 & 580 & 580 & 36 & 3727 \\
\hline $\begin{array}{l}\text { VW } \\
\mathrm{VM}^{+}\end{array}$ & $\begin{array}{l}336 \\
337\end{array}$ & 36 & 36 & $(4979)$ & 36 & 3965 & 584 & No CT & station & taken \\
\hline $\begin{array}{l}\text { VE } \\
\text { Easte } \\
\text { Terra }\end{array}$ & 338 & 40 & 40 & 4668 & 40 & $4675^{*}$ & 585 & 589 & 42 & 4601 \\
\hline DB6 & 912 & $\begin{array}{l}46^{@} \\
47^{@}\end{array}$ & $\begin{array}{l}46^{@} \\
47^{@}\end{array}$ & $\begin{array}{l}4207 \\
4067\end{array}$ & $39^{@}$ & $4160^{\dagger}$ & 591 & 594 & 43 & $(4567)$ \\
\hline DBK & 343 & 44 & 44 & 3614 & 44 & 3652 & 592 & No CT & station & taken \\
\hline
\end{tabular}

Remarks:

( ) - Depths questionable.

$\dagger \quad-$ Minor differences $(\mathrm{O}( \pm 5 \mathrm{~m}))$ between IfM-Kiel and WHOI $\log$ sheets. Depth readings were not taken exactly simultaneously.

$+\quad-\quad$ Mooring lost.

* - Extremely steep local gradients; depth according to bathymetric survey $4646 \mathrm{~m}$.

(1) - Mooring position between adjacent CTD stations. 


\section{Moorings}

The moored array described here was a joint undertaking by IfM-Kiel and WHOI. There were seven IfM-Kiel moorings and six WHOI moorings. The mooring positions for both the IfM-Kiel and WHOI moorings were assigned position identifiers to facilitate the recognition of where each mooring was located. Table 2 lists the position identifiers, the associated mooring identifier and the descriptive position location.

Table 2: Mooring Positions

\begin{tabular}{ccl}
$\begin{array}{c}\text { Position } \\
\text { id }\end{array}$ & $\begin{array}{c}\text { Mooring } \\
\#\end{array}$ & $\begin{array}{l}\text { Descriptive Position } \\
\text { location }\end{array}$ \\
\hline BW & 333 & Brazil Current, West \\
BM & 334 & Brazil Current, Middle \\
BE & 335 & Brazil Current, East \\
VW & 336 & Vema Sill, West \\
VM & 337 & Vema Sill, Middle \\
VE & 338 & Vema Sill, East \\
DBK & 343 & Deep Basin, Kiel \\
DB1 & 906 & Deep Basin, \#1 \\
DB2 & 907 & Deep Basin, \#2 \\
DB3 & 908 & Deep Basin, \#3 \\
DB4 & 909 & Deep Basin, \#4 \\
DB5 & 910 & Deep Basin, \#5 \\
DB6 & 912 & Deep Basin, \#6 \\
\hline
\end{tabular}

Details about mooring location, dates, and instrument depth are shown in Table 3. Representative mooring designs are shown in Figure 4 (IfM-Kiel) and Figure 5 (WHOI). 


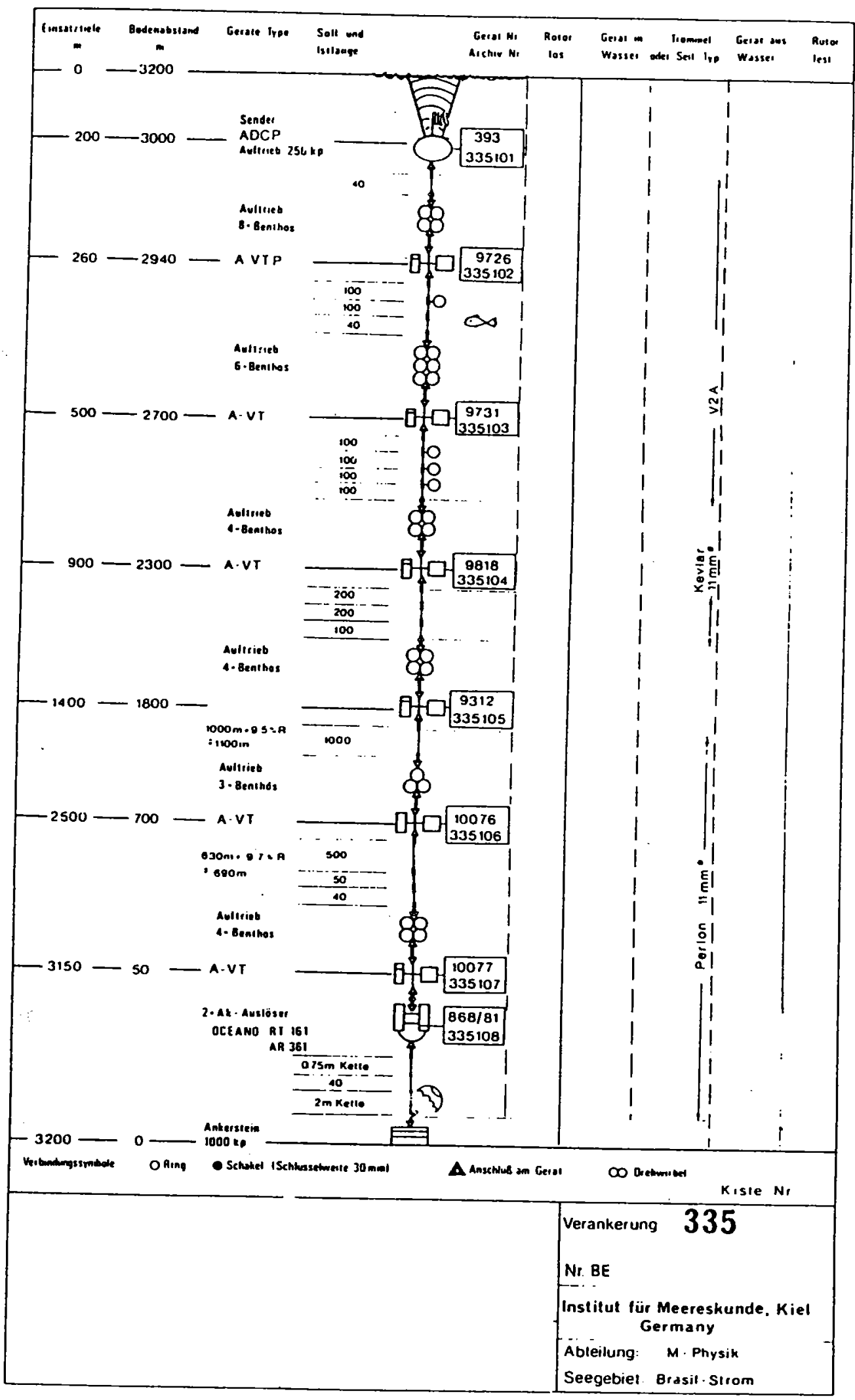

Figure 4: Representative mooring design for IfM-Kiel 


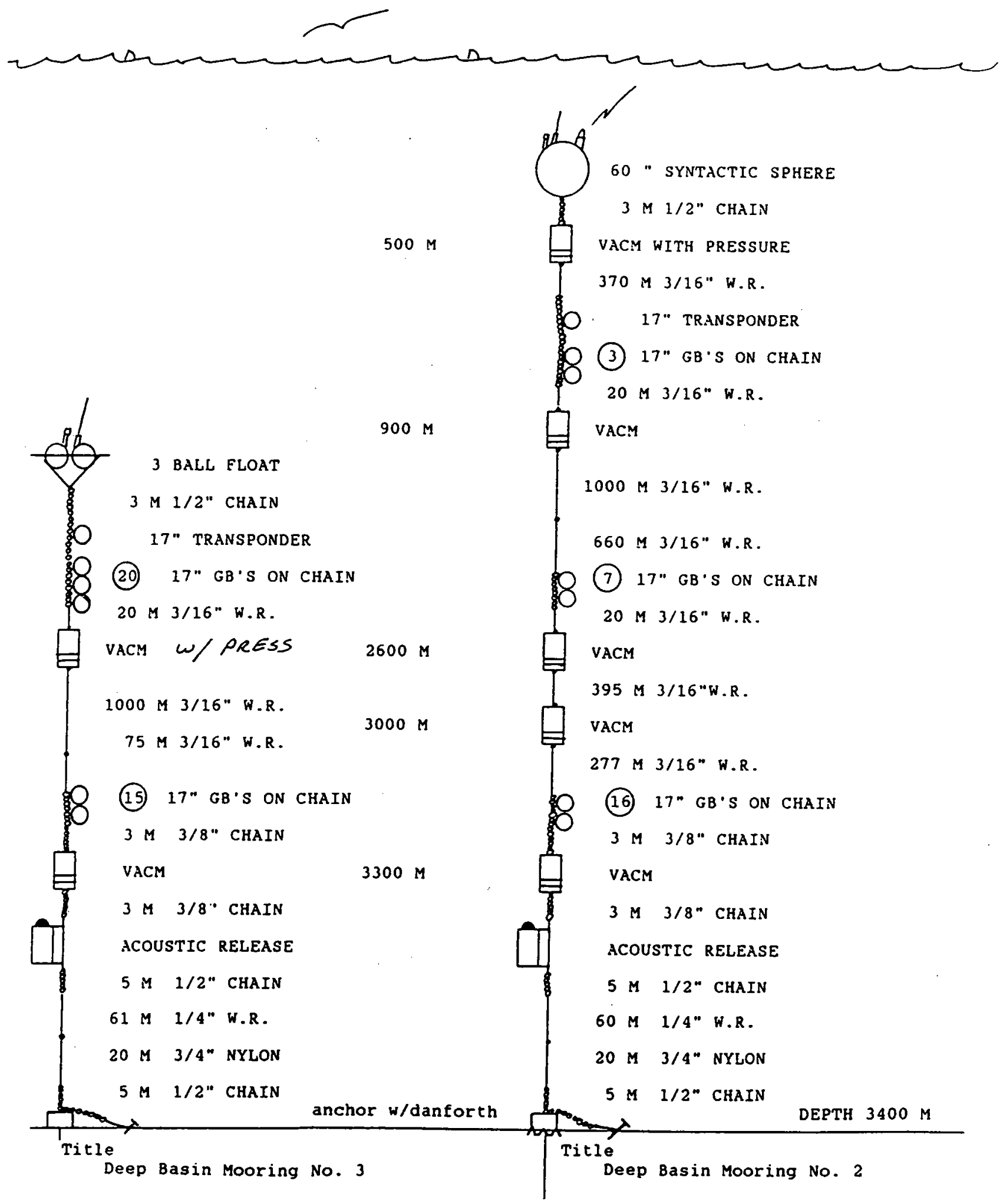

Figure 5: Representative mooring design for WHOI 
Table 3: Deep Basin Moorings, Southern Rim of Brazil Basin

\begin{tabular}{|c|c|c|c|c|c|c|c|c|}
\hline $\begin{array}{c}\text { Mooring } \\
\text { Numbers }\end{array}$ & $\begin{array}{c}\text { Latitude S } \\
\text { Deg/Min }\end{array}$ & \multicolumn{2}{|c|}{$\begin{array}{c}\text { Longitude W } \\
\text { Deg/Min }\end{array}$} & \multicolumn{2}{|c|}{$\begin{array}{c}\text { Mag } \\
\operatorname{Var}(W)\end{array}$} & $\begin{array}{c}\text { Launch } \\
\text { yymmdd }\end{array}$ & $\begin{array}{l}\text { Recover } \\
\text { yymmdd }\end{array}$ & $\begin{array}{c}\text { No. Data } \\
\text { Days } \\
\end{array}$ \\
\hline \multicolumn{9}{|l|}{ WHOI } \\
\hline DB1 906 & 2827.98 & \multicolumn{2}{|c|}{4427.96} & \multicolumn{2}{|c|}{18.5} & 910104 & 921203 & 699 \\
\hline DB2 907 & 2902.56 & \multicolumn{2}{|c|}{4329.65} & \multicolumn{2}{|c|}{19.5} & 910105 & 921204 & 699 \\
\hline DB3 908 & 2932.00 & \multicolumn{2}{|c|}{4242.15} & \multicolumn{2}{|c|}{19.0} & 910106 & 921204 & 698 \\
\hline DB4 909 & 3005.19 & \multicolumn{2}{|c|}{4144.18} & \multicolumn{2}{|c|}{19.5} & 910107 & 921205 & 697 \\
\hline DB5 910 & 3034.99 & \multicolumn{2}{|c|}{4047.36} & \multicolumn{2}{|c|}{20.0} & 910108 & 931009 & 772 \\
\hline DB6 912 & 3104.88 & \multicolumn{2}{|c|}{3909.40} & \multicolumn{2}{|c|}{20.5} & 910111 & 921207 & 696 \\
\hline \multicolumn{9}{|l|}{ IfM-Kiel } \\
\hline BW 333 & 2754.12 & \multicolumn{2}{|c|}{4642.24} & \multicolumn{2}{|c|}{18.0} & 910101 & 921127 & 694 \\
\hline BM 334 & 2759.12 & \multicolumn{2}{|c|}{4620.30} & \multicolumn{2}{|c|}{17.0} & 910101 & 921127 & 694 \\
\hline BE 335 & 2816.12 & \multicolumn{2}{|c|}{4513.48} & \multicolumn{2}{|c|}{18.0} & 910103 & 921126 & 692 \\
\hline VW 336 & 3112.18 & 3946. & & 20.5 & & 910109 & 921206 & 696 \\
\hline VM 337 & 3109.80 & 3926 & & 20.5 & & 910109 & lost & \\
\hline VE 338 & 3108.24 & 3926. & & 20.5 & & 910111 & 921206 & 694 \\
\hline DBK 343 & $\begin{array}{ll}31 & 09.18 \\
\end{array}$ & 3849. & & 20.5 & & 910112 & 921207 & 694 \\
\hline & Instrume & nt Dep & ths (A) & ll Dept & hs in 1 & Meters) & $\begin{array}{l}\text { Water } \\
\text { Depth }\end{array}$ & \\
\hline & WHOI & & & & & & & \\
\hline & DB1906 & 509 & 908 & 2609 & 3009 & 3532 & 3632 & \\
\hline & DB2 907 & 496 & 895 & 2595 & 2995 & 3850 & 3950 & \\
\hline & DB3 908 & & & 2592 & & 3918 & 4019 & \\
\hline & DB4 909 & 514 & 914 & 2614 & 3013 & 3714 & 3814 & \\
\hline & DB5 910 & & & 2597 & & $3621^{*}$ & 3721 & \\
\hline & DB6 912 & & & 2587 & 2988 & 4060 & 4160 & \\
\hline
\end{tabular}

\begin{tabular}{|c|c|c|c|c|c|c|c|c|c|c|c|c|}
\hline & \multicolumn{11}{|c|}{ Instrument Depth (All Depths in Meters) } & $\begin{array}{l}\text { Water } \\
\text { Depth }\end{array}$ \\
\hline \multicolumn{13}{|l|}{ IfM-Kiel } \\
\hline BW 333 & 175 & 220 & 460 & 670 & 875 & & & & & & & 1179 \\
\hline BM 334 & & 280 & 530 & & 930 & 1430 & 2137 & & & & & 2187 \\
\hline BE 335 & 235 & 280 & 550 & & 950 & 1450 & 2545 & 3208 & & & & 3258 \\
\hline VW 336 & & & 425 & & 840 & & 2970 & 3590 & 3915@ & & & 3965 \\
\hline VE 338 & & & & 720 & 1100 & & 2900 & 3850 & 4150 & 4425 & 4625 & $4675^{\dagger}$ \\
\hline DBK 343 & & $285^{\ddagger}$ & 525 & & 925 & & 3025 & 3602 & & & & 3652 \\
\hline
\end{tabular}

Remarks: ${ }^{*}=$ Instrument Lost; ${ }^{\circledR}=$ Instrument Flooded; ${ }^{\dagger}=$ Due to the extreme deep topographic gradient this value may differ by about 30 meters; ${ }^{\ddagger}=$ No Data. 
The moorings were deployed on Meteor Cruise 15, leg 1, a voyage that began in Rio de Janeiro on December 30, 1990, and ended there on January 16, 1991. A total of 57 conventional current meters (Aanderaa and VACM) plus two Acoustic Doppler Current Profilers (ADCP) were set on the 13 moorings. CTDs were taken at each mooring site (see Table 1) as well as in between. Additional details of Meteor Cruise 15 are given by

Siedler and Zenk (1992) and some scientific results, pertinent to the moored array work, are published by Speer et al. (1992), Speer and Zenk (1993), and Zenk et al. (1993a). Eleven moorings were retrieved on Meteor Cruise 22, legs 3 and 4, which originated in Recife on November 18, 1992, and terminated in Rio de Janeiro on December 22, 1992, after a call in Santos (November 30-December 1) giving approximately 23 months of time series data. Again hydrographic stations were taken, although not with such fine spatial resolution as on the first cruise. Details of Meteor 22 have been summarized by Siedler et al. (1993).

Of the two moorings that were not recovered on Meteor 22, one IfM-Kiel mooring is considered lost, the WHOI mooring was partially recovered by dragging for it in October 1993 using a "ship of opportunity", the R/V Maurice Ewing, from the Lamont-Doherty Earth Observatory (LDEO). The top part of the mooring, including one instrument, was recovered.

\section{Pressure Sensor Performance}

The pressure data from the Aanderaa and VACMs were not corrected for sensor drift. Sensor drift for the VACMs was less than 12 decibars. Sensor drift for the Aanderaa instruments was difficult to determine as flotation damage on some moorings during deployment gave the mooring less buoyancy. Table 4 lists the unfiltered pressure minimum 
and maximum values. Plots of filtered pressure versus time can be seen in the composite plots section.

\begin{tabular}{llrrrr}
\multicolumn{7}{c}{ Table 4: Pressure Sensor Data } \\
$\begin{array}{c}\text { Mooring } \\
\text { ID }\end{array}$ & $\begin{array}{c}\text { Data } \\
\text { Name }\end{array}$ & $\begin{array}{r}\text { Inst. } \\
\text { Depth } \\
\text { (m) }\end{array}$ & $\begin{array}{c}\text { Minimum } \\
\text { Pressure } \\
\text { (dbar) }\end{array}$ & Maximum & Difference \\
\hline DB1 & 9061 & 509 & 503 & 521 & 18 \\
DB1 & 9063 & 2609 & 2640 & 2658 & 18 \\
DB2 & 9071 & 496 & 489 & 515 & 26 \\
DB3 & 9081 & 2592 & 2622 & 2661 & 39 \\
DB4 & 9091 & 514 & 489 & 497 & 8 \\
DB4 & 9093 & 2614 & 2634 & 2638 & 4 \\
DB5 & 9101 & 2597 & 2616 & 2625 & 9 \\
DB6 & 9121 & 2587 & 2611 & 2617 & 6 \\
BW & 333102 & 220 & 215 & 401 & 186 \\
BW & 333103 & 460 & 460 & 615 & 155 \\
BM & 334101 & 280 & 242 & 1041 & 799 \\
BM & 334102 & 530 & 456 & 1193 & 637 \\
BE & 335102 & 280 & 242 & 706 & 464 \\
BE & 335103 & 550 & 560 & 1076 & 516 \\
VW & 336101 & 425 & 420 & 453 & 33 \\
VW & 336102 & 840 & 832 & 857 & 25 \\
VE & 338101 & 720 & 690 & 822 & 152 \\
VE & 338102 & 1100 & 1055 & 1175 & 116 \\
DBK & 343203 & 925 & 918 & 942 & 24
\end{tabular}

\section{Instrumentation}

\subsection{Aanderaa Current Meters (RCMs)}

With the exception of two instruments (see 6.2) IfM-Kiel exclusively used current meters manufactured by Aanderaa, Inc., Nestun, Norway (Aanderaa, 1983, 1987). Two different models were used: the classical type, RCM5, using an electromechanical encoder with tape recording; and the more advanced vector averaging type, RCM8, with a solid state data memory module. RCM5 instruments were used only in mooring DBK/334. 
Both models use paddle wheels or Savonius rotors to measure speed. The whole instrument can spin around the mooring wire guided by a current vane. Directions are observed by an electromechanical compass inside the instrument.

All Aanderaa current meters are equipped with temperature sensors. Optional sensors for pressure and electrical conductivity are available. Where they are not installed, they can be replaced by high resolution thermometers (Arctic range, $-2.64 \leq T<5.62^{\circ} \mathrm{C}$. Under normal conditions all non-current sensors are calibrated before and after instrument deployment at IfM-Kiel.

Basic internal differences between RCM5 and RCM8 are summarized in Table 5.

Table 5: Characteristics and Technical Differences between Aanderaa Current Meter Types RCM5 and RCM8 used by IfM-Kiel in the DBE Array

\begin{tabular}{lllllllr}
$\begin{array}{l}\text { Aanderaa } \\
\text { Type }\end{array}$ & $\begin{array}{l}\text { Manufac- } \\
\text { tured }\end{array}$ & $\begin{array}{l}\text { Data } \\
\text { Storage }\end{array}$ & $\begin{array}{l}\text { Vector } \\
\text { Avg. }\end{array}$ & $\begin{array}{l}\text { Time } \\
\text { Rec. }\end{array}$ & $\begin{array}{l}\text { Rotor } \\
\text { Sensor }\end{array}$ & $\begin{array}{l}\text { Sample } \\
\text { Interval }\end{array}$ & $\begin{array}{c}\text { Elementary } \\
\text { Sample }\end{array}$ \\
\hline RCM5 & $1965-1990$ & $\begin{array}{l}\text { Magnetic } \\
\text { Tape }\end{array}$ & No & No & R or P & $120 \mathrm{~min}$ & 1 \\
RCM8 & $>1987$ & $\begin{array}{l}\text { Solid } \\
\text { State }\end{array}$ & Yes & Yes & P & $120 \mathrm{~min}$ & $80-100^{*}$ \\
\hline \multicolumn{5}{c}{$\begin{array}{l}* \\
\text { R Instrument-dependent; originally uninfluenced by operator. } \\
\text { P = Paddle wheel }\end{array}$}
\end{tabular}

CTD data were used to adjust the temperatures in the time series from the IfM-Kiel moorings. 


\subsection{Acoustic Doppler Current Profilers (ADCPs)}

Moored ADCPs record the three-dimensional current components. They range up to about $300 \mathrm{~m}$, typical vertical resolution is of the order of $8 \mathrm{~m}$. Forty-five bins were chosen for the total profile. Internal calculations yield instrument inclination (pitch and roll) and orientation (heading) against magnetic north (flux gate compass).

ADCPs utilize Doppler frequency shifts for speed observations. A pulse of 153 $\mathrm{kHz}$ is radiated from four different transducers. Elementary measurements (pings) are ensembled, averaged and are stored in Electrical Programmable Read Only Memories (EPROMs). The accuracy of the ping data depends on ray inclination and the number of bins chosen. The manufacturer's specification indicates an accuracy of 2-6 $\mathrm{cm} \mathrm{s}^{-1}$ for the horizontal components (RDI, 1989). Ensemble averaging increases this modest accuracy by a factor of $2-4$.

In addition to the three-dimensional current distribution, an "error" velocity is measured. It contains a measure for the heterogeneity of the current field (Visbeck, 1993).

\subsection{Vector Averaging Current Meters (VACMs)}

Vector averaging current meters (VACMs) were developed at WHOI in the early 1970's and were built by EG\&G Ocean Products. They use a Savonius rotor to measure current flow, an external vane to measure the instrument's orientation to the current, and an internal compass to measure the instrument's orientation to magnetic north. Temperature is measured with a thermistor mounted in the end cap of the instrument. The VACM uses a crystal-controlled time reference with an accuracy to within one second per day. The "clock" is synchronized with Universal Temps Coordonne (UTC) before deployment and the accrued error recorded after recovery. The VACM continuously sums vector increments 
of water flow sensed by the rotor and vane. At regular intervals, for this deployment every fifteen minutes, it records on a magnetic tape cassette the accumulated east-west and north-south velocities. The calibration of the VACM and its recording technique were discussed by McCullough (1975). Temperature values are averaged over the entire recording interval of 15 minutes for those instruments that do not measure pressure. The instruments that have both a pressure and temperature sensor are multiplexed, that is they time-share the recording interval and average each sensor's input for one half the recording interval (7.5 minutes). Payne et al. (1976) discussed the accuracy of the temperature measurements. The WHOI temperature sensors were calibrated in the laboratory both before and after deployment. The pressure sensor is a strain gauge with a manufacturer's specified accuracy of about $0.1 \%$, or 3 decibars for a standard 3,000 decibar pressure transducer. The pressure transducers are calibrated both before and after deployment.

\section{Data Processing}

The initial data processing for each instrument was done independently at the originating institution for that instrument. Some additional processing, including the low-passed filtering was done at WHOI.

\subsection{Aanderaa - IfM-Kiel}

The data processing followed the usual procedures. Data were transferred to DOS formatted disc files. In the case of RCM5 instruments a tape reader was needed. Alternatively, the data flow from the RCM8 instruments is directed by an interface box controlling

the attached Data Storing Unit of the individual current meters. Both devices-tape reader 
and I/F box-provide a serial output, RS232. The raw data were edited and converted into engineering units.

Although the vector averaging scheme of the RCM8 uses a cartesian coordinate system internally, raw data from this instrument group are converted again to polar coordinates prior to storage. This transformation makes RCM5 and RCM8 nominally compatible for the subsequent processing. Calibration polynomials are applied to records of temperature, pressure, speed and direction. Inferred quantities, like zonal (U) and meridional (V) current components are calculated simultaneously. The magnetic deviation (shown in Table 3) had to be considered as well.

The following processing steps included time base controls, truncation, removal of bad data and spikes. Finally depths of instruments were corrected against pressure records and with consideration of the mooring designs.

Further processing of the Aanderaa data was done at WHOI to remove an artificial gap in the direction data that occurred at $360^{\circ}$ minus the magnetic variation correction. It appeared that the data that should have been in the gap had been forced to become values on either side of the gap. It further appeared that zero velocities were frequently associated with this phenomenon. Therefore, a simple program was written to test for all cases when the direction was between $335^{\circ}$ and $345^{\circ}$, and the speed was zero. If both cases were true, the data from that record would become a linearly interpolated value. Table 6 lists the results of this program. A brief assessment of data quality for each instrument is shown in Table $8 \mathrm{~b}$. 
Table 6: Number of Data Cycles changed (by linear interpolation) to Compensate for the Artificial Hole in Direction

\begin{tabular}{|c|c|c|c|c|}
\hline Date ID & $\begin{array}{l}\text { \# data } \\
\text { cycles }\end{array}$ & $\begin{array}{l}\text { \# speed } \\
=\text { zero }\end{array}$ & $\begin{array}{c}\text { \# directions } \\
\text { between } \\
335^{\circ} \text { and } 345^{\circ}\end{array}$ & $\begin{array}{c}\text { \# paired } \\
\text { interpolated } \\
\text { values }\end{array}$ \\
\hline$\overline{\mathrm{BW}} / 333102$ & 8327 & 123 & $\overline{42}$ & $\overline{6}$ \\
\hline BW/333103 & 8327 & 157 & 49 & 1 \\
\hline BW/333104 & 8327 & 905 & 200 & 10 \\
\hline $\mathrm{BW} / 333105$ & 8327 & 1437 & 592 & 55 \\
\hline $\mathrm{BM} / 334101$ & 8327 & 331 & 131 & 4 \\
\hline $\mathrm{BM} / 334102$ & 8327 & 478 & 114 & 6 \\
\hline $\mathrm{BM} / 334103$ & 8327 & 1547 & 231 & 36 \\
\hline $\mathrm{BM} / 334104$ & 8327 & 1613 & 195 & 50 \\
\hline $\mathrm{BM} / 334105$ & 8327 & 2448 & 228 & 85 \\
\hline $\mathrm{BE} / 335102$ & 8306 & 287 & 413 & 181 \\
\hline $\mathrm{BE} / 335103$ & 8306 & 1553 & 200 & 40 \\
\hline $\mathrm{BE} / 335104$ & 8306 & 2333 & 171 & 59 \\
\hline $\mathrm{BE} / 335105$ & 8306 & 2498 & 2367 & 2187 \\
\hline $\mathrm{BE} / 335106$ & 8306 & 2500 & 345 & 107 \\
\hline $\mathrm{BE} / 335107$ & 8306 & 1947 & 240 & 93 \\
\hline VW/336101 & 7545 & 17 & 233 & 0 \\
\hline VW/336102 & 8352 & 916 & 239 & 30 \\
\hline VW/336103 & 8365 & 803 & 571 & 49 \\
\hline VW/336104 & 8351 & 648 & 1070 & 55 \\
\hline $\mathrm{VE} / 338101$ & 8330 & 692 & 269 & 14 \\
\hline VE/338102 & 8330 & 2646 & 248 & 80 \\
\hline VE/338103 & 8330 & 3245 & 2504 & 2437 \\
\hline VE/338104 & 8329 & 1515 & 612 & 50 \\
\hline VE/338105 & 8330 & 89 & 447 & 2 \\
\hline $\mathrm{VE} / 338106$ & 8330 & 1 & 6550 & 0 \\
\hline VE/338107 & 8330 & 16 & 2428 & 1 \\
\hline DBK/34322 & 8330 & 289 & 4 & 0 \\
\hline DBK $/ 34323$ & 4106 & 412 & 1993 & 320 \\
\hline DBK/34324 & 8330 & 768 & 246 & 19 \\
\hline DBK/34325 & 8330 & 1403 & 1078 & 996 \\
\hline
\end{tabular}


The frequency of erroneous zero values in the $\mathrm{U}$ and V components of RCM8 instruments is not totally unexpected. Similar experiences with the high threshold speed are documented by Arhan et al. (1991). Further analysis is underway. There is a strong suspicion that the poor performance of the vector averaging Aanderaa current meter (type RCM8) is caused by the shortness of the individual samples. The integration time appears to be insufficient to match sampling needs at low speeds.

\subsection{ADCP - IfM-Kiel}

The overall performance of the two moored Acoustic Doppler Current Profilers (on the top of moorings BW/333 and BE/335) was excellent. Because the Deep Basin Experiment concentrates on the subthermocline circulation in the subtropical South Atlantic, we have decided to display only selected time series from the two ADCPs. Three velocity time series from each ADCP, at selected depths, were chosen to be displayed. Also displayed are the auxiliary quantities of pitch, roll and heading plus the temperature at the instruments' end plates (Table 7).

\section{Table 7: Selection of ADCP Parameters}

\begin{tabular}{cccc}
$\begin{array}{c}\text { Id/data } \\
\text { Name }\end{array}$ & $\begin{array}{c}\text { Bin } \\
\#\end{array}$ & $\begin{array}{c}\text { Nominal } \\
\text { Depth(m) }\end{array}$ & $\begin{array}{c}\text { Parameters selected } \\
\text { and shown here }\end{array}$ \\
\hline BW/333101 & 14 & 50 & U,V,w,e \\
& 7 & 120 & U,V,w,e \\
& 1 & 170 & U,V,w,e \\
& 0 & 175 & pitch,roll,heading,temp. \\
\hline $\mathrm{BE} / 335101$ & 21 & 50 & U,V,w,e \\
& 11 & 140 & U,V,w,e \\
& 3 & 220 & U,V,w,e \\
& 0 & 235 & pitch,roll,heading,temp. \\
\hline
\end{tabular}

$U, V$ components $=$ zonal, meridional components; $w=$ vertical speed; $e=$ "error" velocity; Bin \# $(0)=$ parameters within the instrument itself 


\subsection{VACM - WHOI}

Data from instrument cassettes (VACMs) were read onto a DOS formatted disc. A special interface card in the PC is needed for this transfer. The data were then transferred from the PC disc to a VAX disc in the BUOY format (Maltais, 1969).

Each time series went through a sequence of programs (Tarbell et al., 1988) that checked the time base and converted the data into scientific units. Then the quality of the data was determined (Table 8a).

Next the individual variables were edited to remove miscellaneous bad points and the launch and retrieval transients. Finally the Best Basic Version (BBV) was created by linearly interpolating through gaps in the data to make an evenly spaced time series. This series is the basis for all further processing. Finally a Gaussian filtered series is created from the BBV with a half-width of 24 hours and subsampled to have one point a day. The Gaussian-filtered time series were used to create all the data displays in this report. A brief assessment for each instrument is shown in Table $8 \mathrm{~b}$. 
Table 8a: Deep Basin Data Quality-WHOI

\begin{tabular}{|c|c|c|c|}
\hline Name & Depth & & Comments \\
\hline 9061 & 509 & Instrument & $\begin{array}{l}\text { - Last } 4 \text { months of data missing, because of tape } \\
\text { advance problems. } \\
\text { - Pressure drift was less than } 2 \text { dbars. } \\
\text { - Bottom rotor pivot screws loose. } \\
\text { - Failed self compute test. }\end{array}$ \\
\hline 9062 & 908 & $\begin{array}{l}\text { Data } \\
\text { Instrument }\end{array}$ & $\begin{array}{l}\text { - Good. } \\
\text { - Good. }\end{array}$ \\
\hline 9063 & 2609 & $\begin{array}{l}\text { Data } \\
\text { Instrument }\end{array}$ & $\begin{array}{l}\text { - Rotor sticking after May } 31,1992 . \\
\text { - Pressure drift of about } 11 \mathrm{dbars.} \\
\text { - Top rotor pivot screws loose. }\end{array}$ \\
\hline 9064 & 3009 & $\begin{array}{l}\text { Data } \\
\text { Instrument }\end{array}$ & $\begin{array}{l}\text { - About } 2 \text { months of data available. } \\
\text { - Low tape usage. } \\
\text { - Rotor out of pivots }\end{array}$ \\
\hline \multirow[t]{2}{*}{9065} & 3532 & Data & $\begin{array}{l}\text { - Raw data look good but comparison with other } \\
\text { array data looks suspect. }\end{array}$ \\
\hline & - & Instrument & $\begin{array}{l}\text { - Compass failed post cruise check. Not known if } \\
\text { failure occurred during shipping or while deployed } \\
\text { on mooring. }\end{array}$ \\
\hline \multirow[t]{2}{*}{9071} & 496 & Data & $\begin{array}{l}\text { - Only } 2 \text { months of rotor data. Time series short } \\
\text { by } 1.5 \text { months. }\end{array}$ \\
\hline & & Instrument & $\begin{array}{l}\text { - Pressure drift of about } 6 \text { dbars. } \\
\text { - Rotor completely out of pivots. } \\
+ \text { (positive) logic battery very low. }\end{array}$ \\
\hline 9072 & 895 & $\begin{array}{l}\text { Data } \\
\text { Instrument }\end{array}$ & $\begin{array}{l}\text { - Only } 3 \text { months of data. } \\
\text { - Low tape usage. } \\
\text { - Very low motor driver supply. }\end{array}$ \\
\hline 9073 & 2595 & $\begin{array}{l}\text { Data } \\
\text { Instrument }\end{array}$ & $\begin{array}{l}\text { - Good. } \\
\text { - Good. }\end{array}$ \\
\hline
\end{tabular}


Table 8a: Continued

\begin{tabular}{|c|c|c|c|}
\hline Name & Depth & & Comments \\
\hline 9074 & 2995 & Data & $\begin{array}{l}\text { - Use low-passed data with care. } \\
\text { - Do not use basic data as there are too many } \\
\text { gaps in the time series. } \\
\text { - Gaps in basic data caused by tape reading } \\
\text { problems. }\end{array}$ \\
\hline 9075 & 3850 & $\begin{array}{l}\text { Data } \\
\text { Instrument }\end{array}$ & $\begin{array}{l}\text { - Good. } \\
\text { - Screws on upper rotor pivot loose. }\end{array}$ \\
\hline 9081 & 2592 & $\begin{array}{l}\text { Data } \\
\text { Instrument }\end{array}$ & $\begin{array}{l}\text { - Good; strong eddy. } \\
\text { - Pressure drift of about } 10 \text { dbars. } \\
\text { - Good. }\end{array}$ \\
\hline 9082 & 3918 & $\begin{array}{l}\text { Data } \\
\text { Instrument }\end{array}$ & $\begin{array}{l}\text { - Good; strong eddy. } \\
\text { - Rotor has loose screws on bottom pivot but rotor } \\
\text { still spins freely. }\end{array}$ \\
\hline 9091 & 514 & Instrument & $\begin{array}{l}\text { - Good; beautiful lunar signal in pressure. } \\
\text { - Pressure drift of about } 5 \text { dbars. } \\
\text { - Good. }\end{array}$ \\
\hline 9092 & 914 & $\begin{array}{l}\text { Data } \\
\text { Instrument }\end{array}$ & $\begin{array}{l}\text { - Good. } \\
\text { - Good. }\end{array}$ \\
\hline 9093 & 2614 & Instrument & $\begin{array}{l}\text { - Good. } \\
\text { - A beautiful lunar signal in pressure. } \\
\text { - Pressure drift of about } 2 \text { dbars. } \\
\text { - Good. }\end{array}$ \\
\hline 9094 & 3013 & $\begin{array}{l}\text { Data } \\
\text { Instrument }\end{array}$ & $\begin{array}{l}\text { - No sea data. } \\
\text { - Tape jammed about Dec 29, } 1991 .\end{array}$ \\
\hline 9095 & 3714 & $\begin{array}{l}\text { Data } \\
\text { Instrument }\end{array}$ & $\begin{array}{l}\text { - Good. } \\
\text { - Good. }\end{array}$ \\
\hline
\end{tabular}


Table 8a: Continued

\begin{tabular}{|c|c|c|c|}
\hline Name & Depth & & Comments \\
\hline 9101 & 2597 & Instrument & $\begin{array}{l}\text { - Good. Mooring recovered by dragging } \\
\text { - data continues until Feb } 19,1993 ; \\
\text { - pressure drift of about } 3 \text { dbars. } \\
\text { - Instrument recovered by dragging. } \\
\text { - Tape full. }\end{array}$ \\
\hline 9102 & 3621 & Data & - No data; instrument not recovered. \\
\hline 9121 & 2587 & $\begin{array}{l}\text { Data } \\
\text { Instrument }\end{array}$ & $\begin{array}{l}\text { - Good. } \\
\text { - Pressure drift of }-4 \text { dbars then }+4 \text { dbar. } \\
\text { - Good. }\end{array}$ \\
\hline 9122 & 2988 & Data & $\begin{array}{l}\text { - Use low passed data with care. } \\
\text { - About } 5 \% \text { of the basic series are interpolated } \\
\text { values. }\end{array}$ \\
\hline 9123 & 4060 & Instrument & $\begin{array}{l}\text { - Tape reading problems caused many errors in } \\
\text { the data. } \\
\text { - About } 2 \% \text { of the basic series are interpolated } \\
\text { values. } \\
\text { - Rotor has one loose screw. }\end{array}$ \\
\hline
\end{tabular}


Table 8b: Deep Basin Data Quality-IfM-Kiel

\begin{tabular}{|c|c|c|c|}
\hline Name & Depth & & Comments \\
\hline 333 & & Mooring & $\begin{array}{l}\text { - The uppermost buoyancy-element was damaged. } \\
\text { Perhaps the whole mooring, including anchor, } \\
\text { moved downslope caused by large current drag. }\end{array}$ \\
\hline 333101 & 175 & Data & $\begin{array}{l}\text { - ADCP first results adequate }(100 \% \text { data }) \\
\text { - Temp shows the same dives as the ACM below. }\end{array}$ \\
\hline & & Instrument & - \\
\hline 333102 & 220 & $\begin{array}{l}\text { Data } \\
\text { Instrument }\end{array}$ & $\begin{array}{l}\text { - Strong pressure events of about } 180 \text { dbars. } \\
\text { - Rotor stuck for } 10 \text { days in Sept } 1992 .\end{array}$ \\
\hline 333103 & 460 & $\begin{array}{l}\text { Data } \\
\text { Instrument }\end{array}$ & - Good. Strong pressure events of 150 dbars. \\
\hline 333104 & 670 & Data & $\begin{array}{l}\text { - Threshold problem in speed (and, therefore, in } \\
\mathrm{U}, \mathrm{V} \text { ). }\end{array}$ \\
\hline 333105 & 875 & $\begin{array}{l}\text { Instrument } \\
\text { Data } \\
\text { Instrument }\end{array}$ & - Threshold problem in speed. \\
\hline 334 & & Mooring & - The uppermost buoyancy-element was damaged. \\
\hline 334101 & 280 & Data & $\begin{array}{l}\text { - Strong dives of } 700 \text { dbars maximum. } \\
\text { - Jump of } 35 \text { dbars in pressure after first big dive. }\end{array}$ \\
\hline & & Instrument & 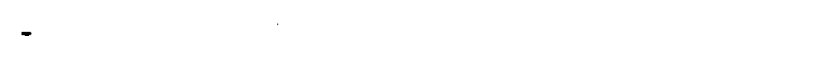 \\
\hline 334102 & 530 & $\begin{array}{l}\text { Data } \\
\text { Instrument }\end{array}$ & - Good. \\
\hline 334103 & 930 & $\begin{array}{l}\text { Data } \\
\text { Instrument }\end{array}$ & $\begin{array}{l}\text { - Threshold problem in speed. } \\
\text { - Rotor stuck for } 10 \text { days in early August. }\end{array}$ \\
\hline 334104 & 1430 & $\begin{array}{l}\text { Data } \\
\text { Instrument }\end{array}$ & $\begin{array}{l}\text { - Threshold problem in speed. } \\
\text { - }\end{array}$ \\
\hline 334105 & 2137 & $\begin{array}{l}\text { Data } \\
\text { Instrument }\end{array}$ & $\begin{array}{l}\text { - Threshold problem in speed. } \\
\text { - }\end{array}$ \\
\hline
\end{tabular}


Table 8b: Continued

\begin{tabular}{|c|c|c|c|}
\hline Name & Depth & & Comments \\
\hline \multirow[t]{2}{*}{335101} & 235 & Data & $\begin{array}{l}\text { - Data before February } 13 \text { not included due to } \\
\text { technical difficulties. }\end{array}$ \\
\hline & & Instrument & - ADCP buoyancy was damaged upon recovery. \\
\hline \multirow[t]{3}{*}{335102} & 280 & Data & - Strong pressure events of about $450 \mathrm{dbars}$. \\
\hline & & & - $40 \mathrm{db}$ pressure drop after major event. \\
\hline & & Instrument & - Rotor lost. \\
\hline \multirow[t]{3}{*}{335103} & 550 & Data & $\begin{array}{l}\text { - Initial pressure values removed because of un- } \\
\text { reasonable data. It seems to be a sensor problem. }\end{array}$ \\
\hline & & & - Threshold problem in speed. \\
\hline & & Instrument & - \\
\hline \multirow[t]{2}{*}{335104} & 950 & Data & - Threshold problem in speed. \\
\hline & & Instrument & -One of 6 rotor paddles lost upon recovery. \\
\hline \multirow[t]{2}{*}{335105} & 1450 & Data & $\begin{array}{l}\text { - Many zero counts in speed and direction. An } \\
\text { instrument, not a data processing problem. }\end{array}$ \\
\hline & & Instrument & - \\
\hline \multirow[t]{2}{*}{335106} & 2545 & Data & - Threshold problem in speed. \\
\hline & & Instrument & - \\
\hline \multirow[t]{2}{*}{335107} & 3208 & Data & - Threshold problem in speed. \\
\hline & & Instrument & - \\
\hline \multirow[t]{2}{*}{336101} & 425 & Data & $\begin{array}{l}\text { - No registration until March } 18,1991 \text {. } \\
\text { - Time base relies on recovery check only. } \\
\text { - No threshold problem in speed!! }\end{array}$ \\
\hline & & Instrument & - \\
\hline 336102 & 840 & $\begin{array}{l}\text { Data } \\
\text { Instrument }\end{array}$ & $\begin{array}{l}\text { - Good. } \\
\text { - Good. }\end{array}$ \\
\hline 336103 & 2970 & $\begin{array}{l}\text { Data } \\
\text { Instrument }\end{array}$ & $\begin{array}{l}\text { - Good. } \\
\text { - Good. }\end{array}$ \\
\hline
\end{tabular}


Table 8b: Continued

\begin{tabular}{|c|c|c|c|}
\hline \multirow{2}{*}{$\frac{\text { Name }}{336104}$} & Depth & \multicolumn{2}{|r|}{ Comments } \\
\hline & 3590 & $\overline{\text { Data }}$ & $\begin{array}{l}\text { - Two-month loss of data (Aug, Sept 1992) caused } \\
\text { by tape reading problem. }\end{array}$ \\
\hline & & Instrument & - \\
\hline 336105 & 3915 & $\begin{array}{l}\text { Data } \\
\text { Instrument }\end{array}$ & $\begin{array}{l}\text { - No data. } \\
\text { - End plate of Aandraa lost. Instrument flooded. }\end{array}$ \\
\hline 337 & & Mooring & - Mooring lost. \\
\hline 338101 & 720 & $\overline{\text { Data }}$ & $\begin{array}{l}\text { - Step of } 50 \text { dbars in pressure signal. } \\
\text { - Rotor sticking for } 10 \text { days in Sept } 1992 \text {. }\end{array}$ \\
\hline & & Instrument & - \\
\hline 338102 & 1100 & Data & $\begin{array}{l}\text { - Strange pressure signal, step of } 50 \mathrm{dbars.} \\
\text { - Threshold problem in speed. }\end{array}$ \\
\hline & & Instrument & - One of six rotor paddles lost on recovery. \\
\hline 338103 & 2900 & $\begin{array}{l}\text { Data } \\
\text { Instrument }\end{array}$ & - Significant threshold problem in speed. \\
\hline 338104 & 3850 & $\begin{array}{l}\text { Data } \\
\text { Instrument }\end{array}$ & - Threshold problem in speed. \\
\hline 338105 & 4150 & $\begin{array}{l}\text { Data } \\
\text { Instrument }\end{array}$ & $\begin{array}{l}\text { - Good. } \\
\text { - Good. }\end{array}$ \\
\hline 338106 & 4425 & $\begin{array}{l}\text { Data } \\
\text { Instrument }\end{array}$ & $\begin{array}{l}\text { - Good. } \\
\text { - Rotor damaged upon recovery. }\end{array}$ \\
\hline 338107 & 4625 & $\begin{array}{l}\text { Data } \\
\text { Instrument }\end{array}$ & $\begin{array}{l}\text { - Good. } \\
\text { - Good. }\end{array}$ \\
\hline
\end{tabular}


Table 8b: Continued

\begin{tabular}{|c|c|c|c|}
\hline Name & Depth & & Comments \\
\hline \multirow[t]{2}{*}{$\overline{343201}$} & 285 & Data & - No data. Registration failed, no obvious reason. \\
\hline & & Instrument & - \\
\hline \multirow[t]{4}{*}{343202} & 525 & Data & - Tape reading and/or registration problems. \\
\hline & & & $\begin{array}{l}\text { - Stuck rotor in Feb } 1992 . \\
\text { - Time series divided into two parts: }\end{array}$ \\
\hline & & & - a) Jan - Aug 1991, b) Jan - June 1992. \\
\hline & & Instrument & - End plate was damaged. \\
\hline \multirow[t]{3}{*}{343203} & 925 & Data & $\begin{array}{l}\text { - Only one year of registration (auxiliary battery } \\
\text { failed). }\end{array}$ \\
\hline & & & - Threshold problem in direction. \\
\hline & & Instrument & - \\
\hline 343204 & 3025 & $\begin{array}{l}\text { Data } \\
\text { Instrument }\end{array}$ & $\begin{array}{l}\text { - Good. } \\
\text { - Good. }\end{array}$ \\
\hline \multirow[t]{2}{*}{343205} & 3602 & Data & - Threshold problem in speed and direction. \\
\hline & & Instrument & - \\
\hline
\end{tabular}

Remark: Similar problems with the threshold speed are documented by Arhan et al. (1991) who performed a series of tests on Aandreaa current meters in their tow tank facility.

\section{Data Identification}

\subsection{IfM-Kiel}

Each time series is identified by a 6 digit ( $X X X Y Z Z)$ mooring number. $X X X$ contains a sequential mooring number, $Y$ identifies repeated launches at the same location, and $Z Z$ stands for the instrument position number counted from above. 
Mooring DBK/343 was launched twice. The first launch yielded no data. This report contains the time series from the second (successful) launch, hence its identification is $3432 Z Z$.

\subsection{WHOI}

Each time series is identified by a mooring number, a sequential instrument position number, a letter to indicate the data version, and numbers to indicate the sampling rate. Therefore, 9081B900 identifies data from the first instrument on mooring 908; the version is $B$, and the sampling rate is one record every 15 minutes (900 seconds). 9081B1DG24 is a time series that has had a Gaussian filter (G) applied to the data; the filter has a half width of 24 hours (24) and is subsampled once a day (1D).

\section{Descriptions of Data Displays}

The first two pages are lists of the statistics for each time series. Following the statistics, the plots are ordered by mooring position from West to East (Figure 1). Data from each mooring are displayed on four consecutive pages, except for the two moorings with ADCP data. Each set of ADCP data (three current time series plus extra variables from the ADCP) are shown on five additional pages that precede the four current meter pages for that mooring.

\subsection{Statistics}

Statistics of U, V and temperature from the filtered time series are included in Table 7 at the beginning of the data presentation section. The ADCP current time series do not 
have an associated temperature; therefore those series display only the statistics for $\mathrm{U}$ and V. The equations used to derive the statistical parameters are described by Tarbell et al. (1988). Table 9 describes the column headings for the statistical table. Units for velocity are $\mathrm{cm} / \mathrm{sec}$ and for temperature are in ${ }^{\circ} \mathrm{C}$.

Table 9: Description of Column Headings for Statistical Table

\begin{tabular}{|c|c|c|}
\hline Column \# & Caption & Description \\
\hline 1 & Data id & $\begin{array}{l}\text { DBE mooring designation; institutional se- } \\
\text { quential number. }\end{array}$ \\
\hline 2 & depth & $\begin{array}{l}\text { Depth of the instrument in meters or, in the } \\
\text { case of the ADCP, the depth of the compo- } \\
\text { nents. }\end{array}$ \\
\hline 3 & $\# \mathrm{dc}$ & $\begin{array}{l}\text { Number of data cycles, which also corre- } \\
\text { sponds to the number of days of data. }\end{array}$ \\
\hline 4 & $\mathrm{U}$ & Mean of the east velocity component. \\
\hline 5 & $\mathrm{~V}$ & Mean of the north velocity component. \\
\hline 6 & K.m & Kinetic energy of the mean. \\
\hline 7 & $\mathrm{U}^{\prime 2}$ & Variance of the east component. \\
\hline 8 & $\mathrm{~V}^{\prime 2}$ & Variance of the north component. \\
\hline 9 & K.e & Eddy kinetic energy. \\
\hline 10 & $\mathrm{U}^{\prime} \mathrm{V}^{\prime}$ & Co-variance of east and north. \\
\hline 11 & $\mathbf{T}$ & Mean temperature. \\
\hline 12 & $\sqrt{T^{\prime 2}}$ & Standard deviation of temperature. \\
\hline 13 & $\mathrm{U}^{\prime} \mathrm{T}^{\prime}$ & $\begin{array}{l}\text { Co-variance of east component and tempera- } \\
\text { ture. }\end{array}$ \\
\hline 14 & $\mathrm{~V}^{\prime} \mathrm{T}^{\prime}$ & $\begin{array}{l}\text { Co-variance of north component and temper- } \\
\text { ature. }\end{array}$ \\
\hline
\end{tabular}




\subsection{Progressive Vector Plots}

Progressive vector diagrams are representative for low-frequency motions recorded by the current meters. Current vectors are placed head to tail to show the path a particle would have traveled in a perfectly homogeneous flow. The plot begins with an asterisk followed by annotated triangles at the first of each month. Each page displays the plots from one mooring. On all moorings (except 338 ) the start asterisk $\left(^{*}\right)$ is positioned on a vertical line. On a few moorings, where the $\mathrm{km} /$ inch scale is greatly different over the depth range, two different $\mathrm{km} /$ inch scales have been used.

\subsection{Variables versus Time}

The composite stick plots, which show individual current vectors as arrows along the time scale, are plotted with the available pressure data for the mooring. The velocity and pressure scales differ for each mooring to best display the character of the measured currents.

Composite temperature plots also use different scales within the same mooring to highlight temperature fluxuations.

A third set of composite plots displays the individual east and north components for each mooring.

\section{Acknowledgements}

Foremost we thank D. Carlsen and A. Kipping (IfM-Kiel) and Scott Worrilow, Dave Simoneau and Kent Bradshaw (WHOI) for their technical help in mooring design and 
and implementation. Their close cooperation with colleagues from the Oceanographic Institute of São Paulo University (IOUSP) and the University of Rio de Janeiro has made our mooring efforts a great success. Special thanks go to the captains and crews of the Research Vessels Meteor and Ewing. Repeated encouragement and support was provided by G. Siedler. T. J. Müller, chief scientist on the Meteor recovered moorings BW, BM and BE. Not forgotten is the excellent cooperation with Y. Ikeda, University of São Paulo, and the staff of German diplomatic representatives in both Brasilia and Rio de Janeiro who helped to clear all necessary allowances from Brazilian authorities. Thanks go to Mike Rawson, Marine Department at LDEO, and the captain and crew of the R/V Ewing for their contributions to the dragging effort that, under the direction of Scott Worrilow in October 1993, recovered part of a "lost" DBE mooring. Thanks also to Penny Foster (WHOI) for her assistance in typing this report.

Financial support for this project came from: Deutsche Forschungsgemeinschaft (Si 111/38-1. Si 111/39-1) Bundesministerium für Forschung und Technologie (03F0535A, 03F0050D, F0121A) and the National Science Foundation Grant OCE -9004396.

\section{References}

Aanderaa Instruments, 1983. Operating Manual RCM 4/5 Technical Description No. 119, July 1983, 84 pp.

Aanderaa Instruments, 1987. Operating Manual, RCM 7/8 Technical Description No. 159, December 1987, $70 \mathrm{pp}$.

Arhan, M., A. Billant, A. Colin de Verdiere, N. Daniault and R. Prego, 1991. Hydrography and velocity measurements offshore from the Iberian Peninsula, Bord-Est, vol. 2. Campagnes Oceanographiques Francaises, Brest, No. 15, 232 pp. 
Cherkis, N. Z., H. S. Fleming and J. M. Brozena, 1989. Bathymetry of the South Atlantic Ocean, $3^{\circ} \mathrm{S}-40^{\circ} \mathrm{S}$. Geological Society of America Map, Chart Ser. MCH 069.

Levy, E., 1983. A compilation of moored instrument data and associated oceanographic observations from the Vema Channel. Vol. 32. W.H.O.I. Technical Report 83-46, 47 , vi pp and 3 fiche.

Maltais, J. A., 1969. A nine channel digital magnetic tape format for storing oceanographic data. W.H.O.I. Ref. 69-55 (Technical Report), 11 pp.

McCullough, J. R., 1975. Vector Averaging Current Meter speed calibration and recording technique. W.H.O.I. Ref. 75-44 (Technical Report), 33 pp.

Mercier, H., K. Speer, and J. Honnorez, 1994. Flow pathways of bottom water through the Romanche and Chain Fracture Zones. Deep-Sea Research, in press.

Payne, R. E., A. L. Bradshaw, J. P. Dean and K. E. Schleicher, 1976. Accuracy of temperature measurements with the V.A.C.M. W.H.O.I. Ref. 76-94 (Technical Report), $78 \mathrm{pp}$.

RDI-Primer, 1989. Acoustic Doppler Current Profilers Principles of Operation: A Practical Primer, RD Instruments, San Diego, $36 \mathrm{pp}$.

Siedler, G. und W. Zenk, 1992. WOCE Südatlantik 1991, Reise Nr. 15, 30. Dezember 1990-23. März 1991. Meteor-Berichte, Univeristät Hamburg, 92-1, 126 S.

Siedler, G., W. Balzer, T. J. Müller, R. Onken, M. Rhein and W. Zenk, 1993. WOCE South Atlantic 1992, Cruise No. 22, 22 September 1992-31 January 1993. MeteorBerichte, Universität Hamburg, 93-5, 131 pp.

Speer, K. G., W. Zenk, G. Siedler, J. Pätzold, and C. Heidland, 1992. First resolution of flow through the Hunter Channel in the South Atlantic. Earth and Planetary Science Letters, 113, 287-292. 
Speer, K. G. and W. Zenk, 1993. The flow of Antarctic Bottom Water into the Brazil Basin. Journal of Physical Oceanography, 12, 2667-2682.

Speer, K. G., H. Mercier, M.-J. Messias and L. Mémery. The Romanche Fracture Zone: Blocking and Mixing of Arctic and Antarctic Waters at the Equator. Journal of Geophysical Research, submitted.

Tarbell, S. A., A. Spencer, and E. T. Montgomery, 1988. The Buoy Group data processing system. Woods Hole Oceanographic Institution Technical Memorandum, WHOI-388,209 pp.

Visbeck, M., 1993. Konvektion im offenen Ozean. Intepretation von Beobachtungen aus der Grönland-see und dem westlichen Mittelmeer. Berichte aus dem Institut für Meereskunde, Kiel, 237, 187 pp.

World Ocean Circulation Experiment, 1990. Towards a Deep Basin Experiment (Core Project 3), 27-28 September 1989; WOCE Report No. 55/90, May 1990. 37 pp.

Zenk, W., T. J. Müller and N. G. Hogg, 1993a. Meteor finished her second DBE cruise. WOCE Newsletter, 14, 4-7.

Zenk, W., K. G. Speer and N. G. Hogg, 1993b. Bathymetry at the Vema Sill, Deep Sea Research, I, 40, No. 9, 1925-1933. 


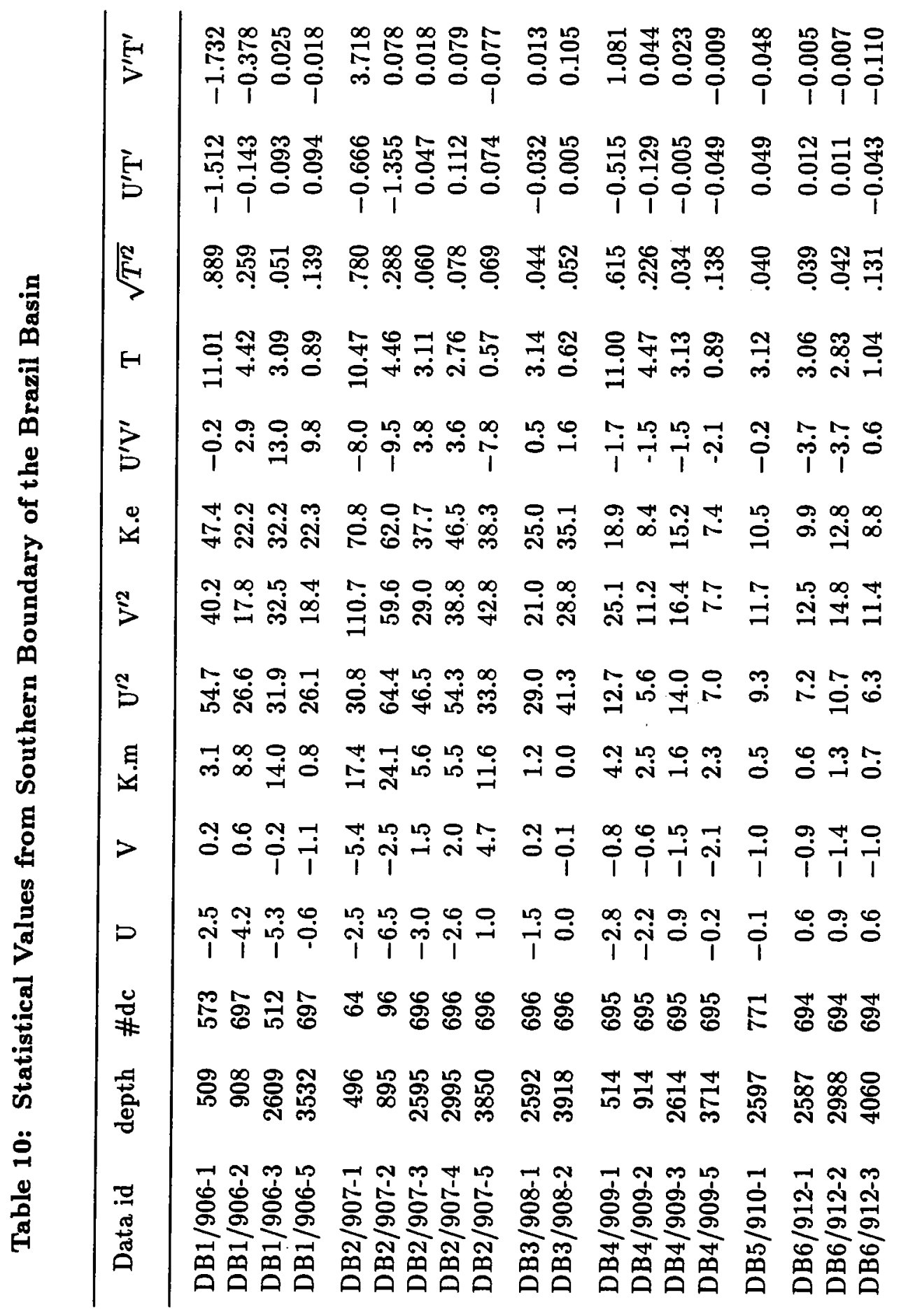




\begin{tabular}{|c|c|c|c|c|c|c|}
\hline$\stackrel{5}{5}$ & & 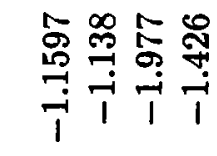 & 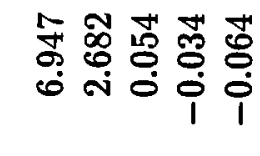 & & 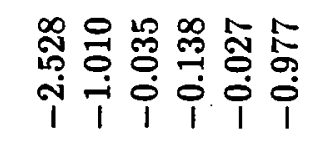 & 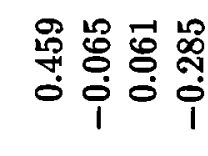 \\
\hline E- & & ホ̦ & 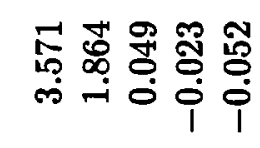 & & 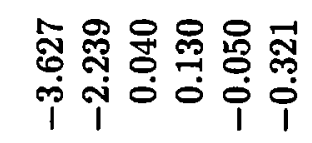 & 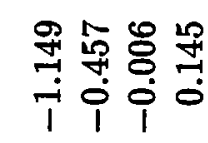 \\
\hline$\tilde{E}$ & & 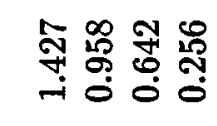 & 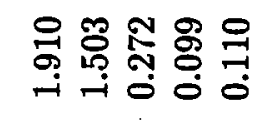 & & 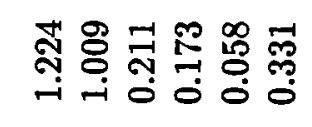 & 葆哭哭哭 \\
\hline$H$ & & 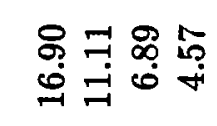 & 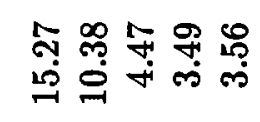 & & 号 & 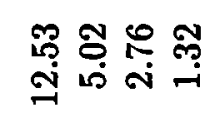 \\
\hline 咅 & 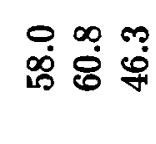 & | & $\underset{1}{\stackrel{1}{1}}$ & 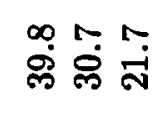 & ণึ๊ & 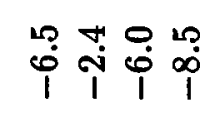 \\
\hline تَغْت & 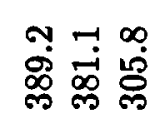 & 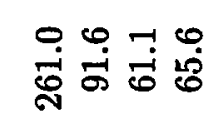 & 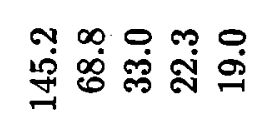 & 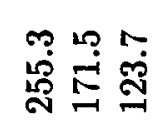 & 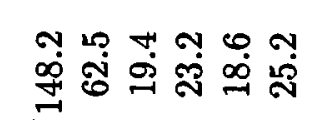 & 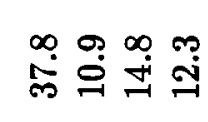 \\
\hline 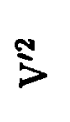 & 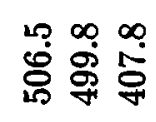 & 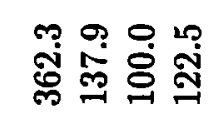 & 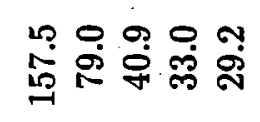 & 边 & 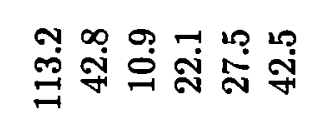 & 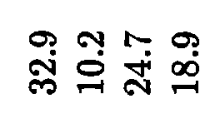 \\
\hline$\tilde{\mathrm{s}}$ & 芒过 & ํำ & 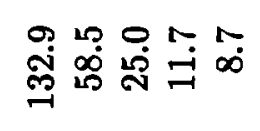 & 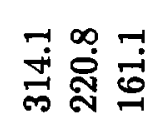 & 珮 & 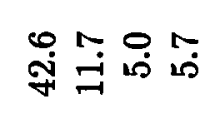 \\
\hline |: & 苞 & 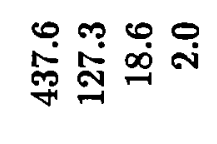 & 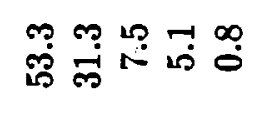 & ن & 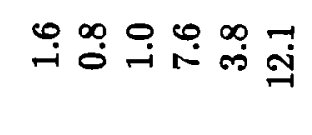 & 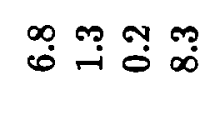 \\
\hline$>$ & 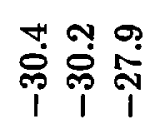 & 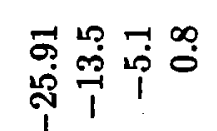 & 華 & $\stackrel{\sim}{\sim} \stackrel{\infty}{\rightarrow}$ & تِ & $\exists \stackrel{m}{0}$ \\
\hline$F$ & 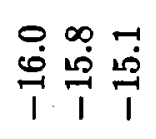 & 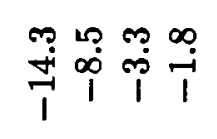 & 递吊 & 1 & 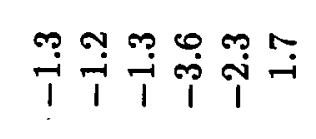 & 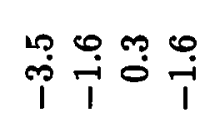 \\
\hline \# & 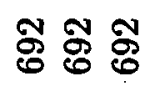 & 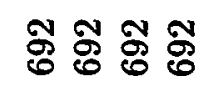 & శ్ & 응 앵 & ి.్రి & 청 항 \\
\hline 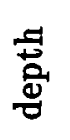 & 오용요 & సิ & 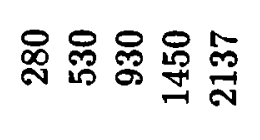 & 옴웜 & 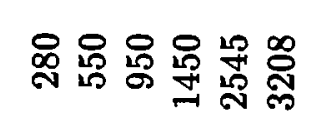 & 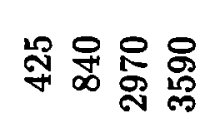 \\
\hline 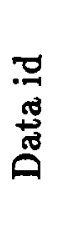 & 总总总 & 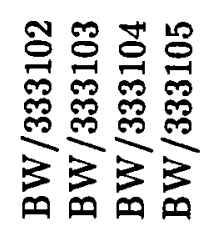 & 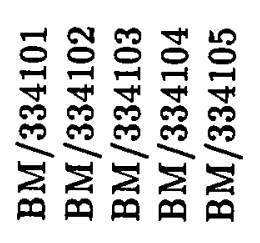 & 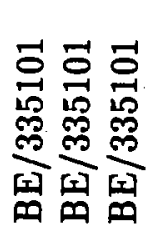 & 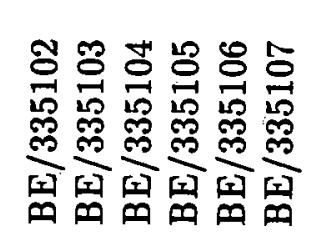 & 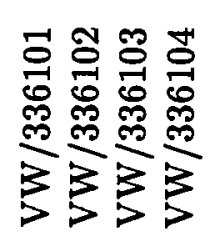 \\
\hline
\end{tabular}




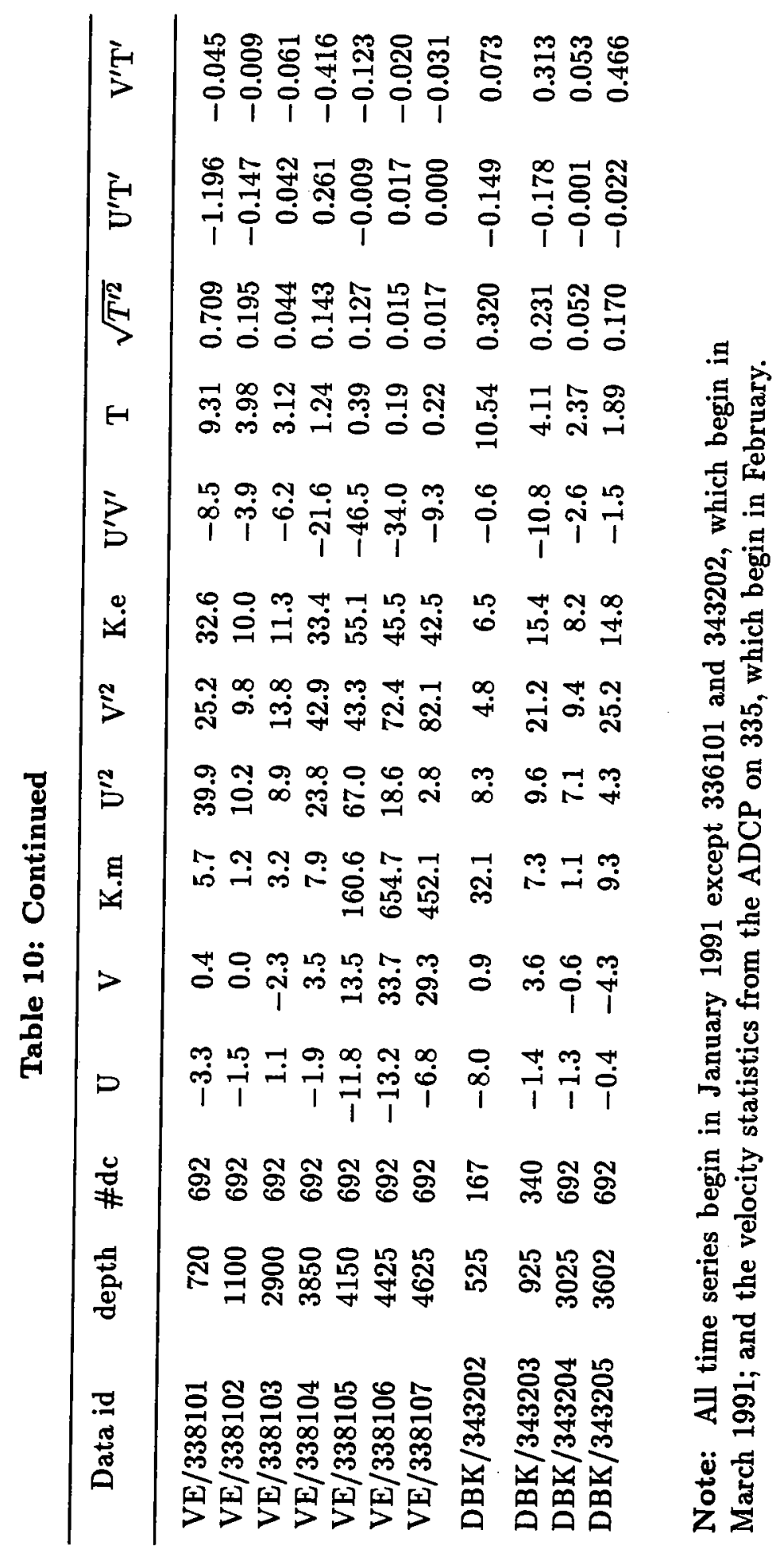




\section{THIS PAGE BLANK}


Mooring $B W / 333$

ADCP vector depths of $50,120,170 \mathrm{~m}$.

Temperature depth at $175 \mathrm{~m}$.

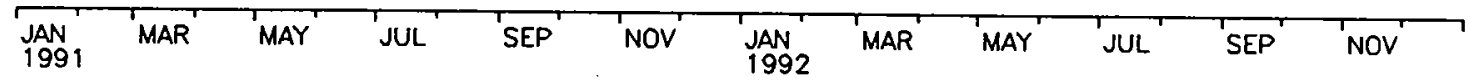

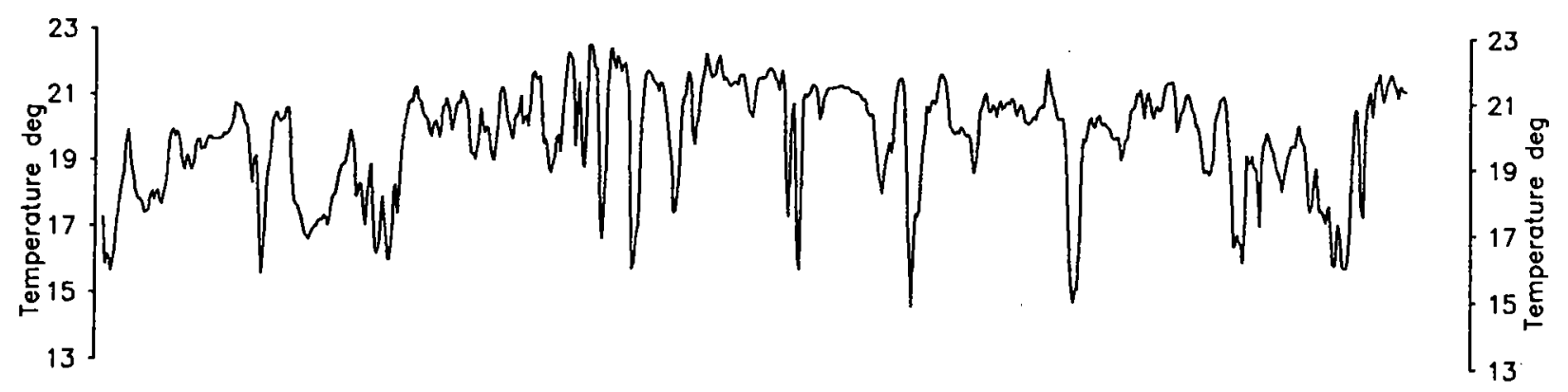
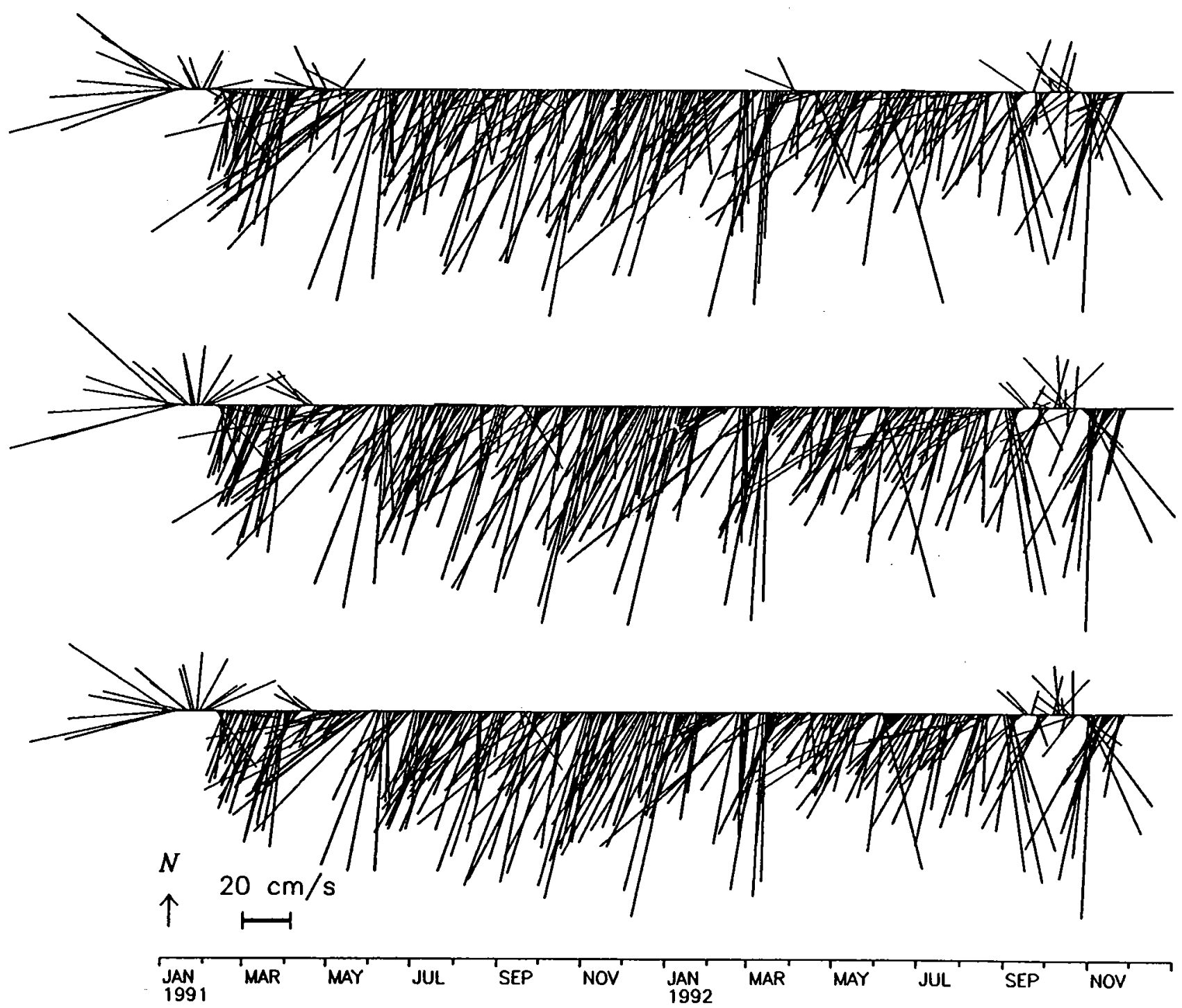


\section{Mooring $333 *$ variables from an ADCP instrument depth of $175 \mathrm{~m}$.}

\begin{tabular}{|c|c|c|c|c|c|c|c|c|c|c|}
\hline $\begin{array}{l}\text { JAN } \\
1991\end{array}$ & MAR & MAY & JUL & SEP & NOV & $\begin{array}{l}\text { JAN } \\
1992\end{array}$ & MAR & MAY & JUL & SEP \\
\hline
\end{tabular}

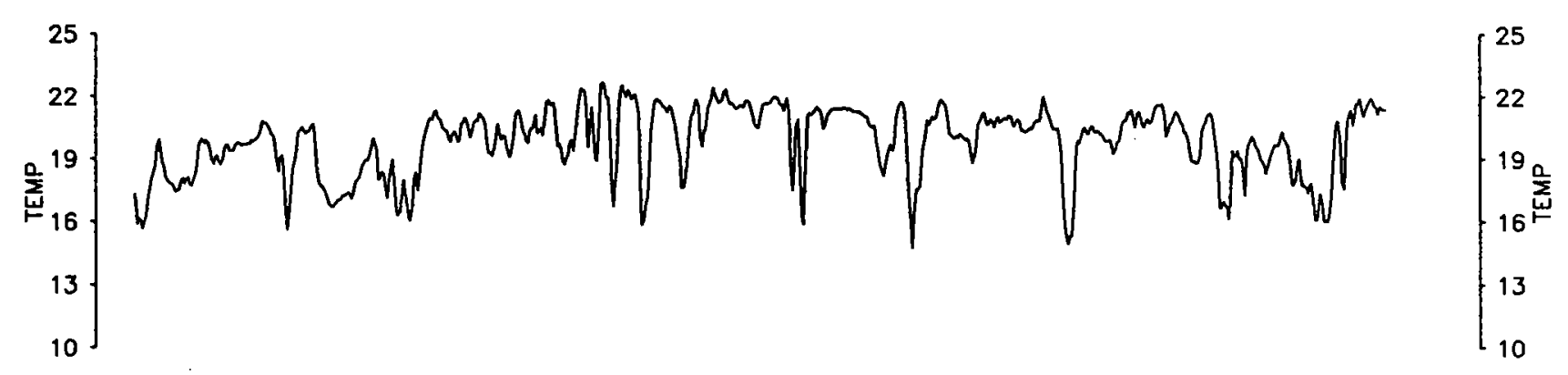

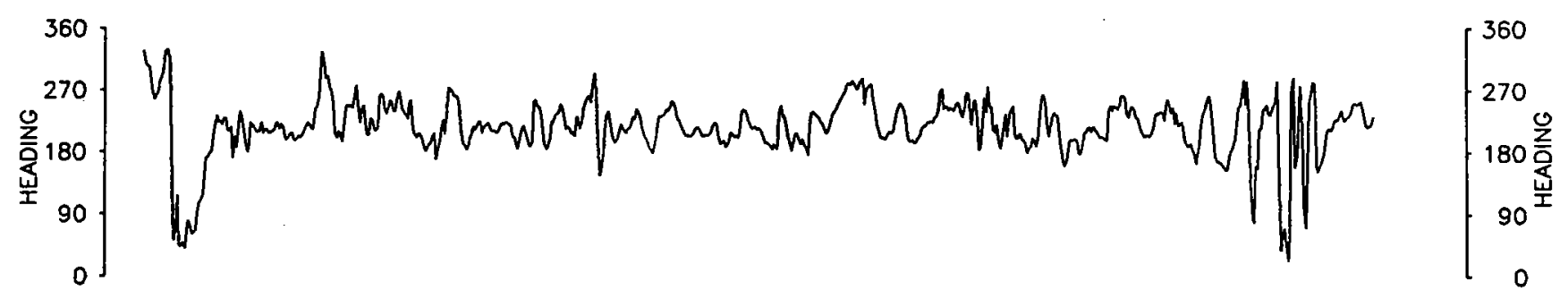

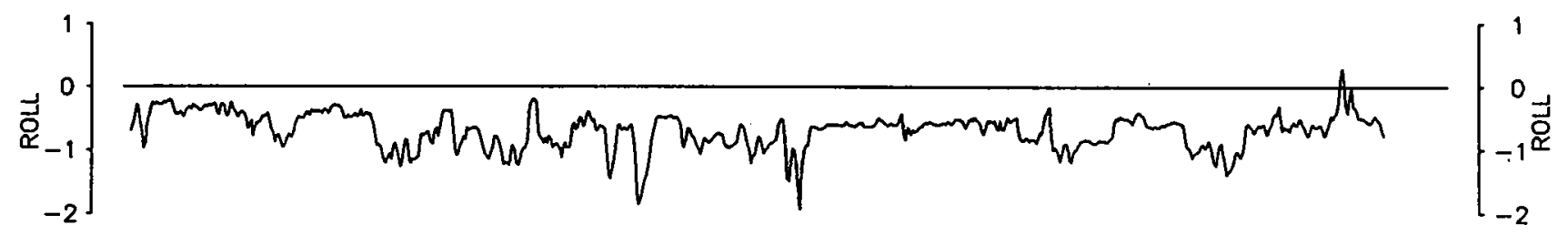

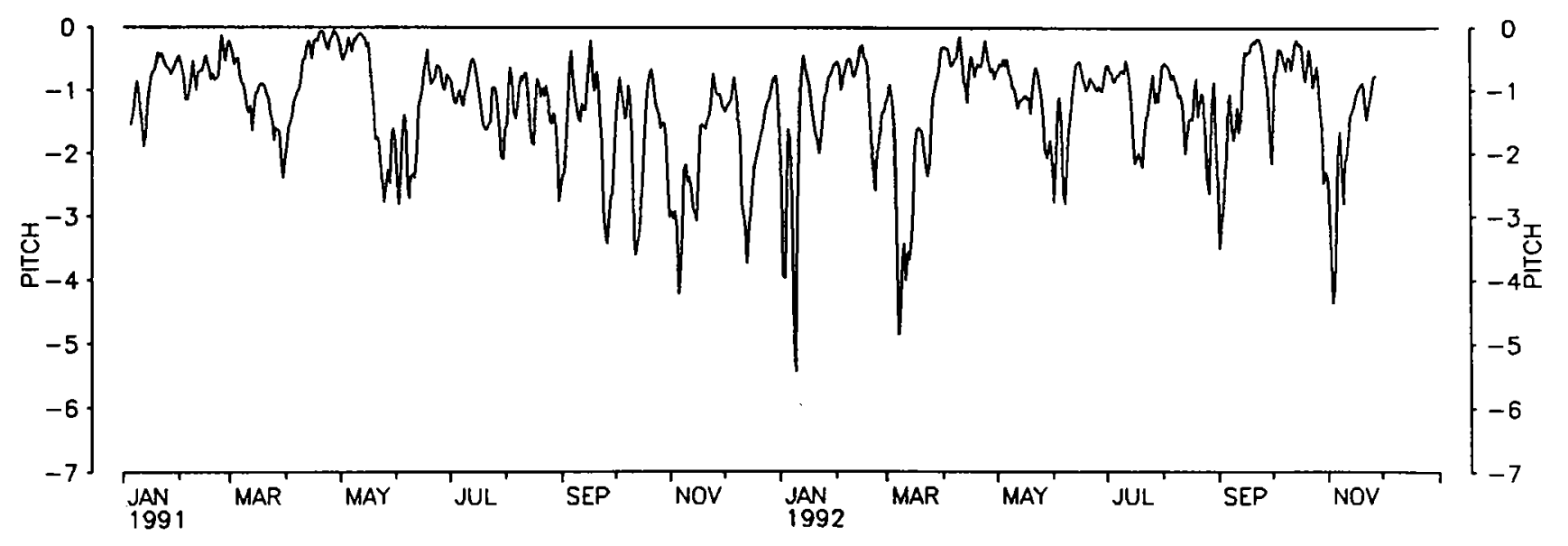


Mooring $333 * U$ and $V$ components from an ADCP depths of $50,120,170 \mathrm{~m}$.

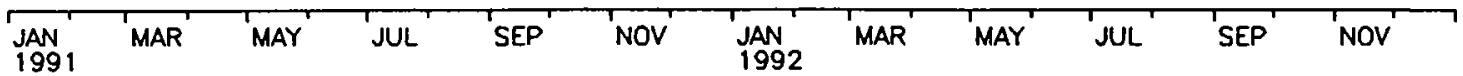
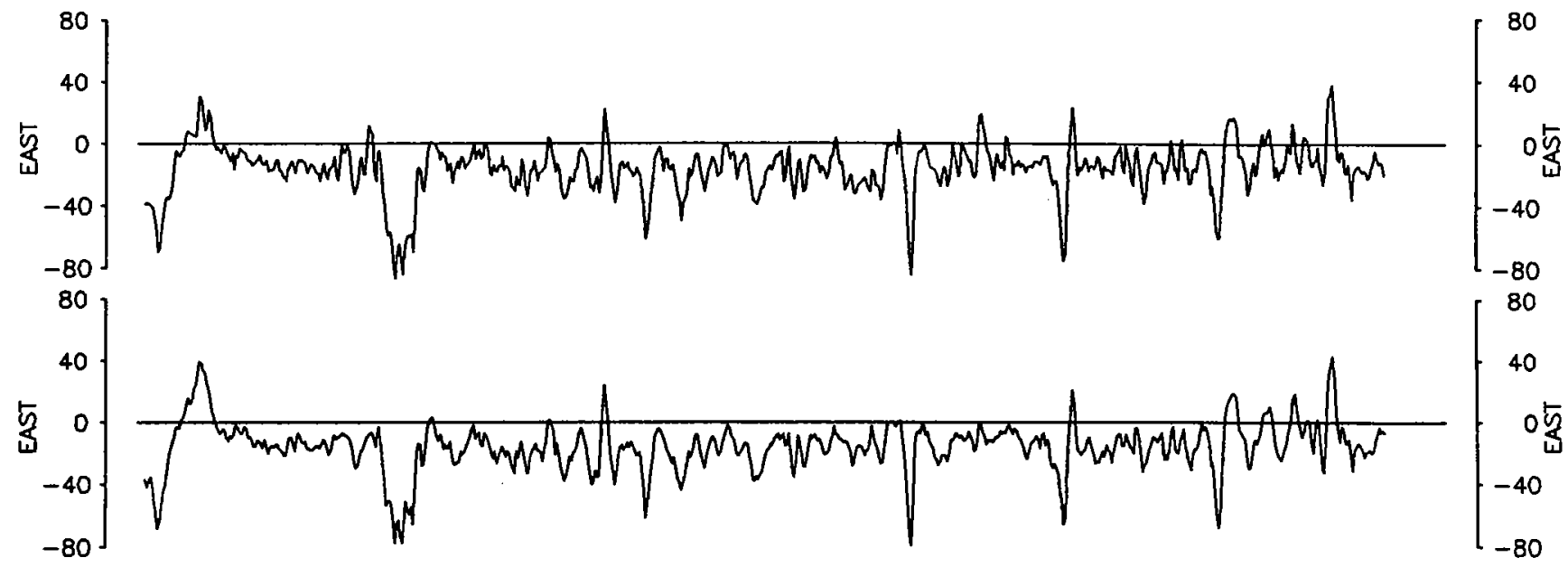

80

40

$\left.\begin{array}{r}80 \\ 40 \\ \text { ธิ } \\ 0 \\ -40 \\ -80\end{array}\right]$

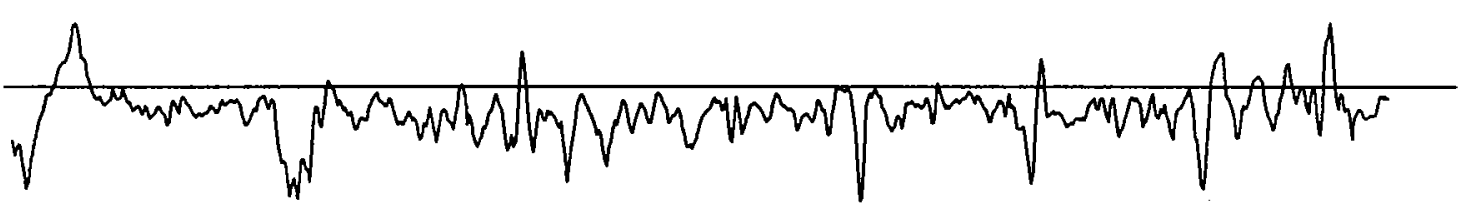

$0 \frac{5}{5}$

-40
-80

80

40

JAN MAR MAY JUL TEP NOV JAN MAR MAY JUL 'SEP NOV
1991

$\left.{ }_{-40}^{\frac{5}{2}}\right]_{80}^{40}$

80
40
$-40^{\frac{I}{2}}$
$\frac{1}{2}$
-80

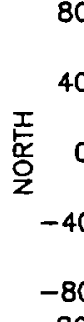

(1)

80

$\ln h$

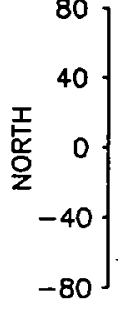

$\frac{\mu h}{h \mu}$

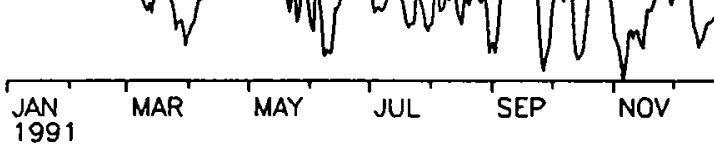




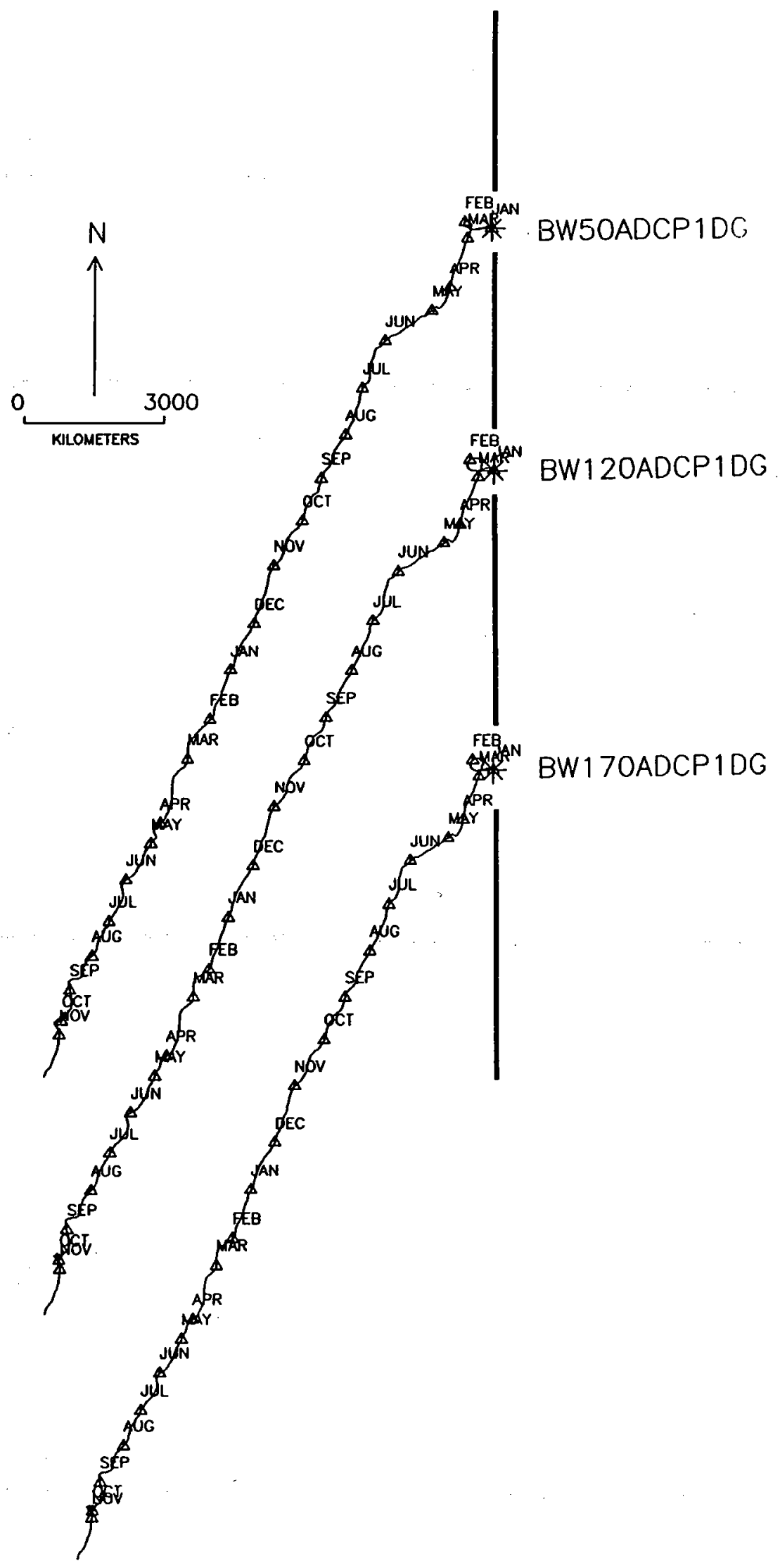


Mooring $333 * W$ and $E$ variables from an ADCP depths of $50,120,170 \mathrm{~m}$.

JAN 'MAR MAY 'JUL' SEP' NOV' JAN 'MAR 'MAY JUL' 'SEP' NOV
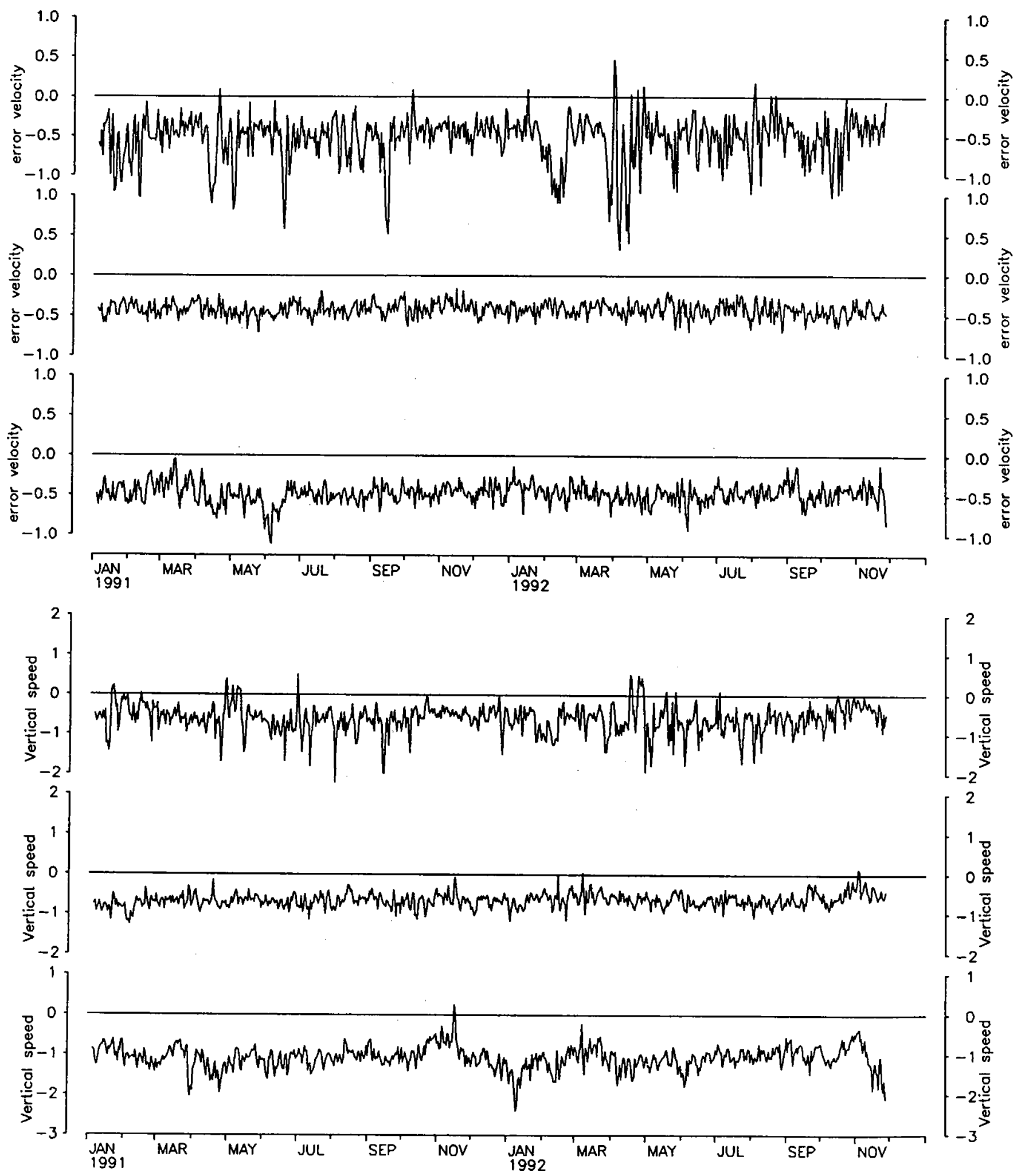


\section{THIS PAGE BLANK}



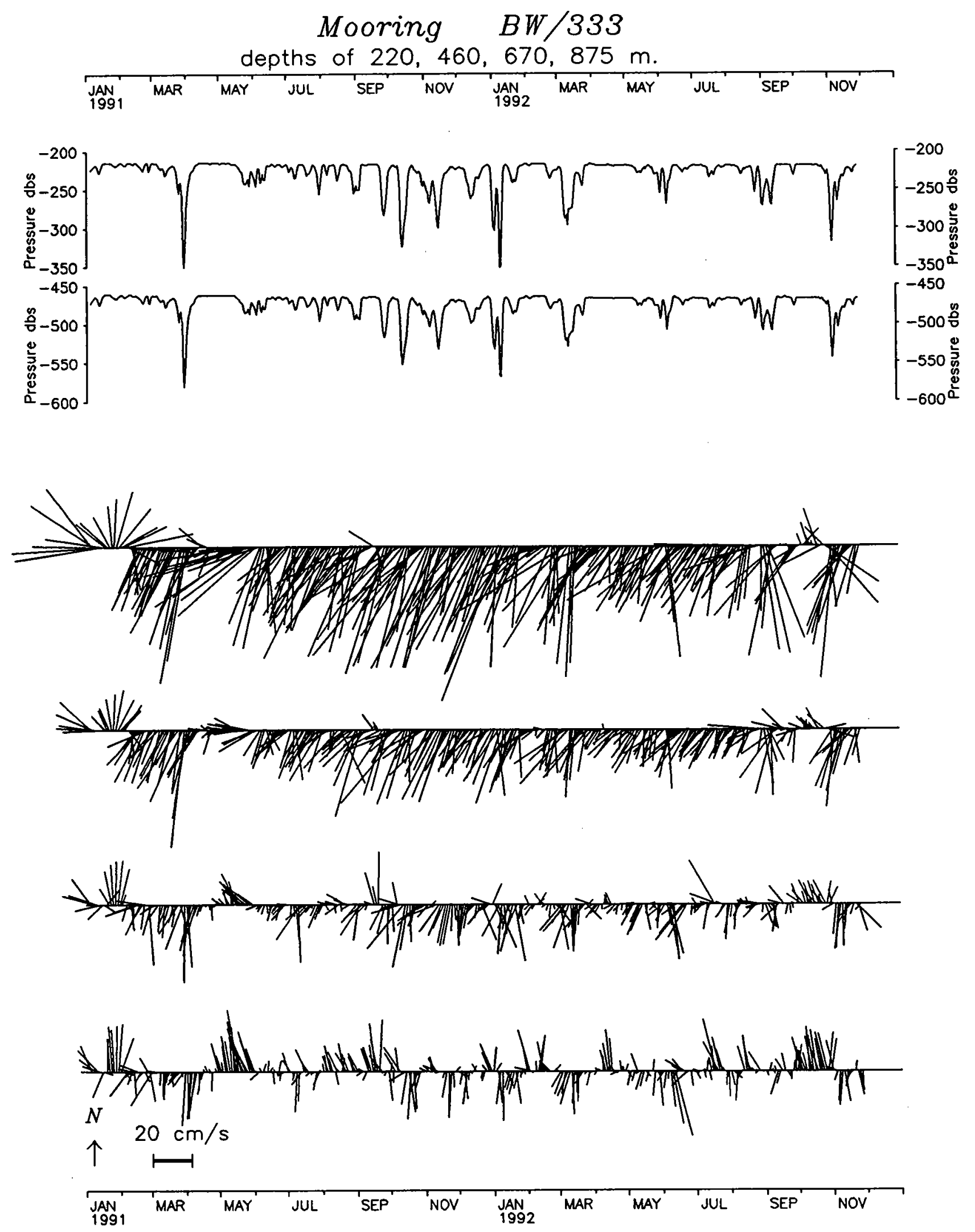
Mooring $\mathrm{BW} / 333$

* Temperatures at 220, 460,670, and 875 meters

JAN 'MAR MAY JUL SEP NOV JAN 'MAR MAY JUL SEP NOV'

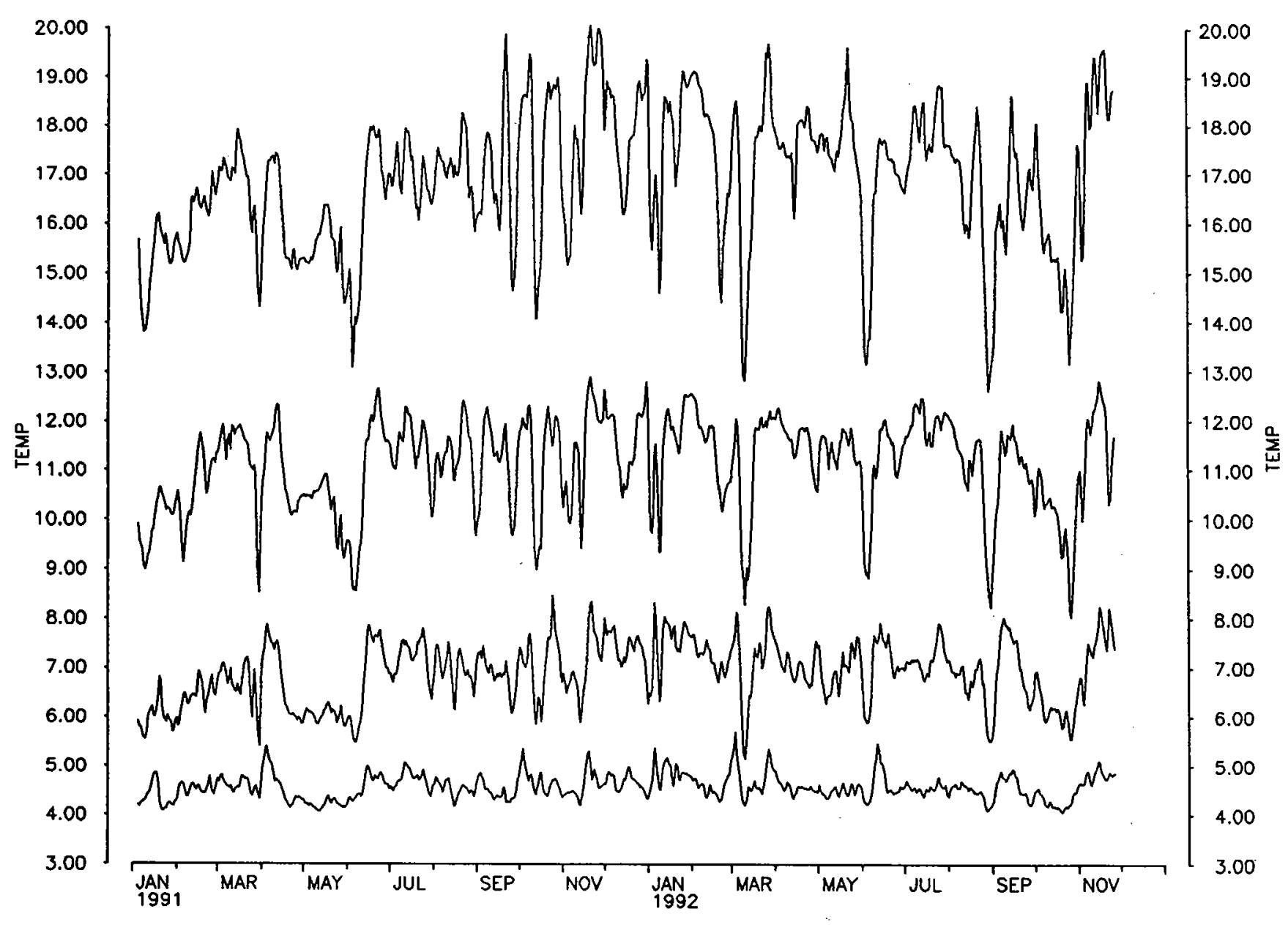




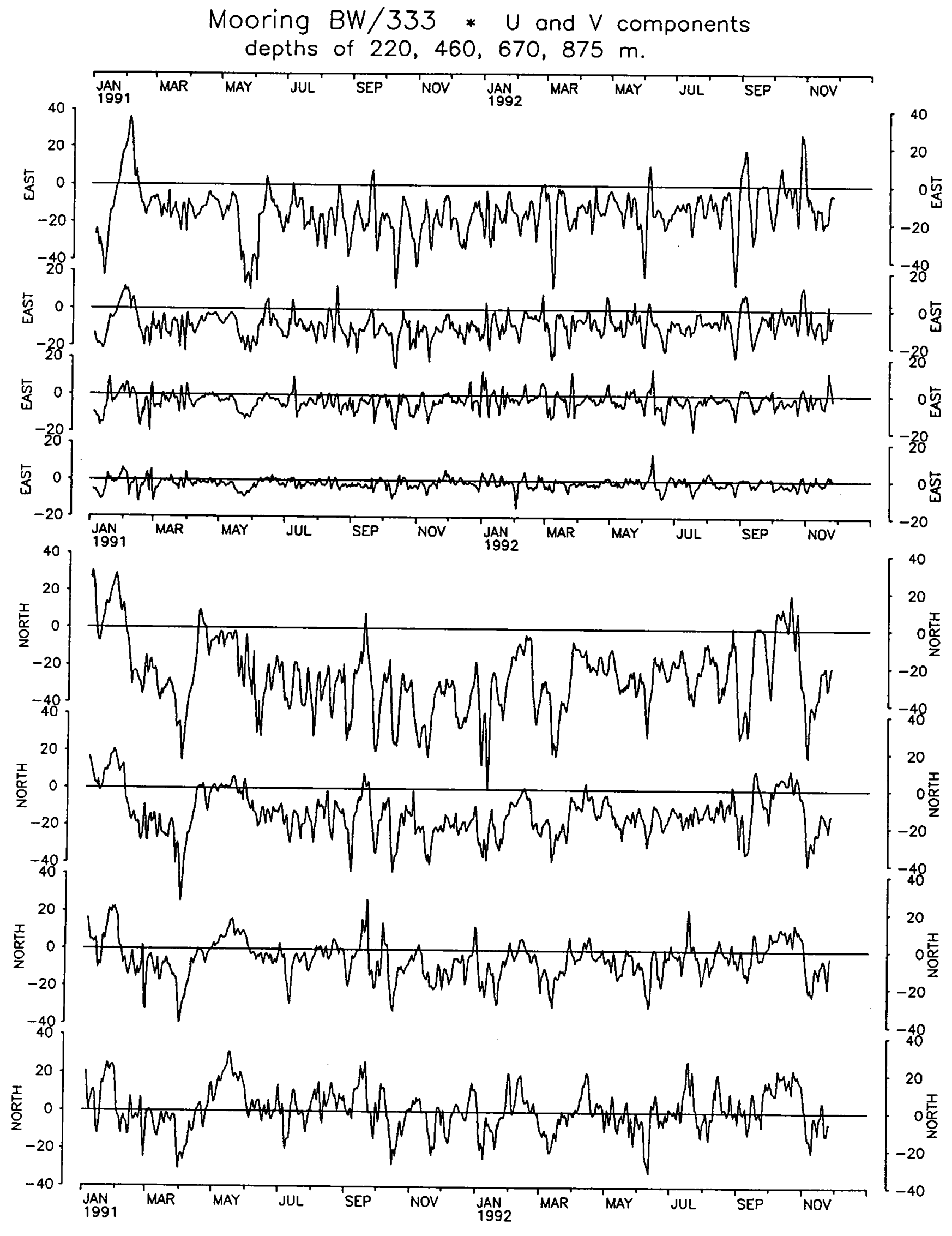




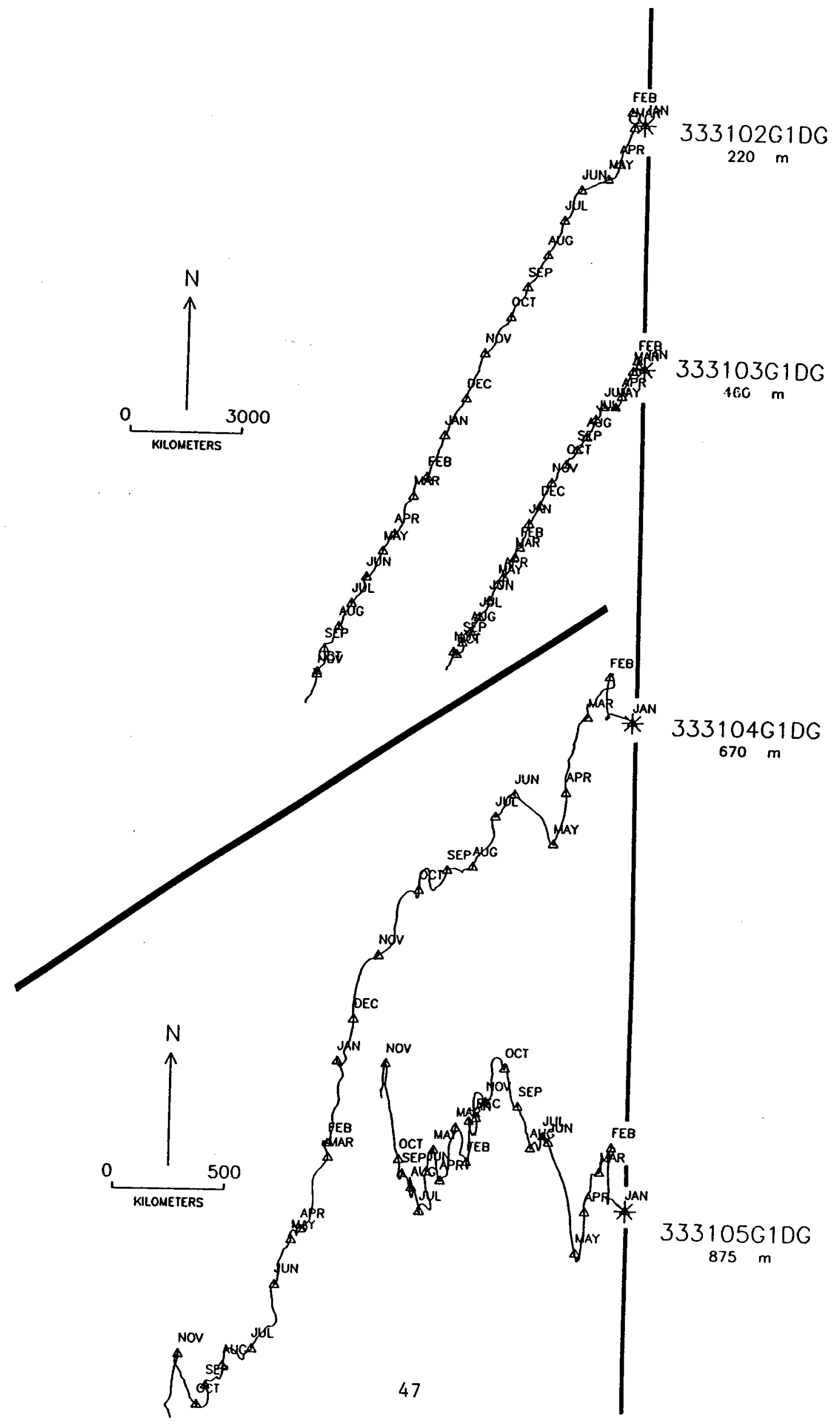


Mooring $B M / 334$

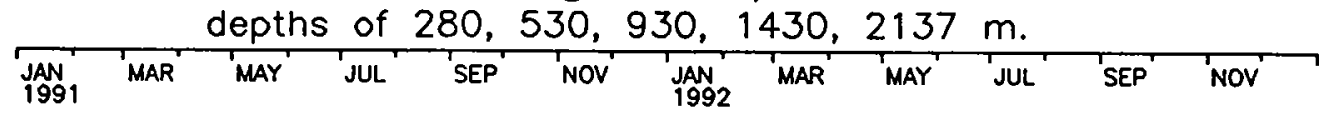

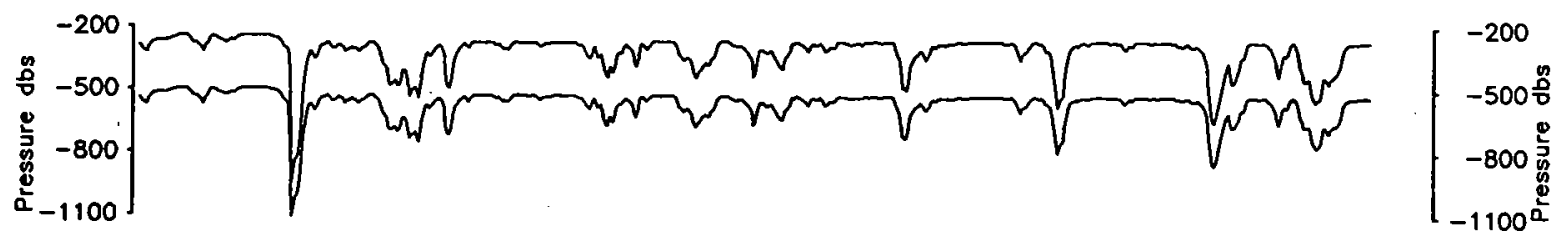
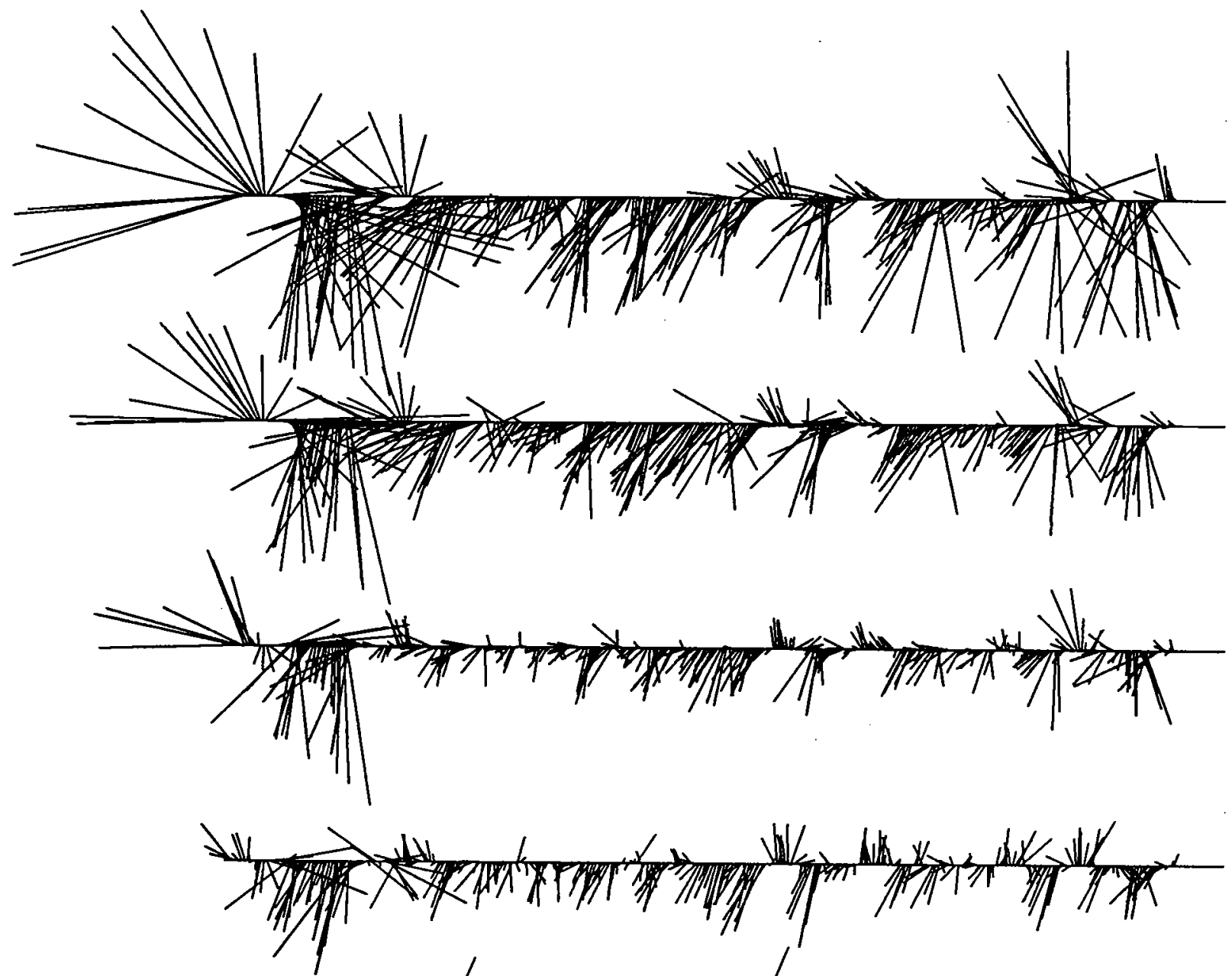

${ }_{N}=10 \mathrm{~cm} / \mathrm{s}$

$\uparrow 10 \mathrm{~cm} / \mathrm{s}$

J9A 'MAR 'MAY 'JUL SEP' 'NOV' JAN 'MAR' MAY 'JUL 'SEP' NOV


Mooring BM/334

* Temperatures at 280,530,930,1430, 2137 meters

JAN' MAR 'MAY JUL SEP NOV JAN 'MAR MAY JUL 'SEP' NOV'

$\sum_{0.50}^{19.00}$

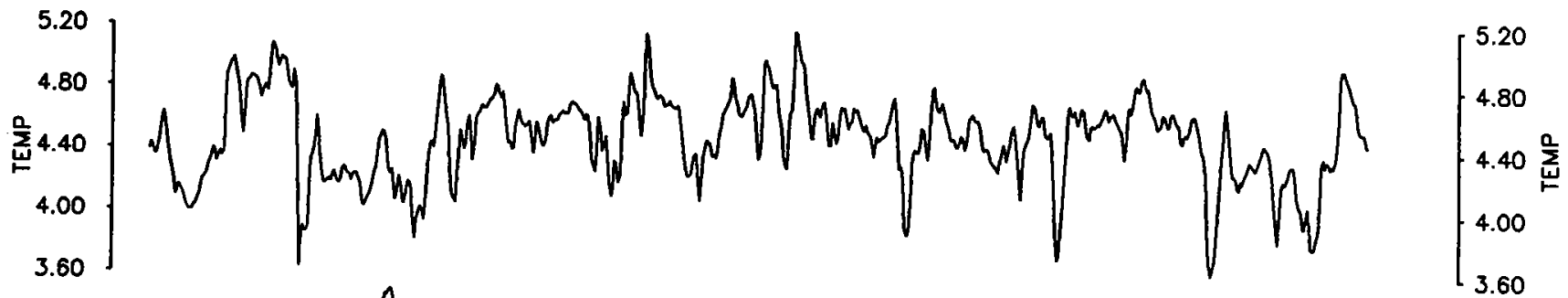

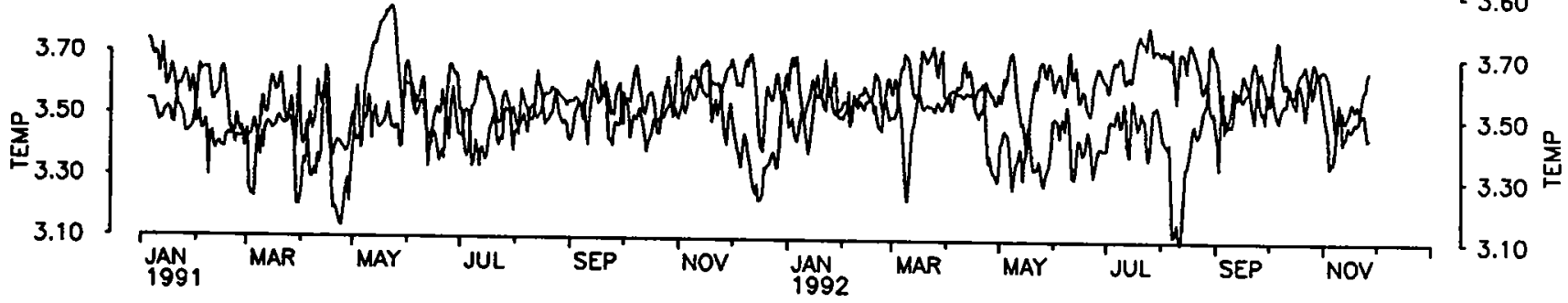


Mooring $\mathrm{BM} / 334 * \mathrm{U}$ and $\mathrm{V}$ components depths of $280,530,930,1430,2137 \mathrm{M}$.

JAN 'MAR' MAY JUL 'SEP 'NOV 'JAN 'MAR 'MAY 'JUL 'SEP 'NOV'
1991
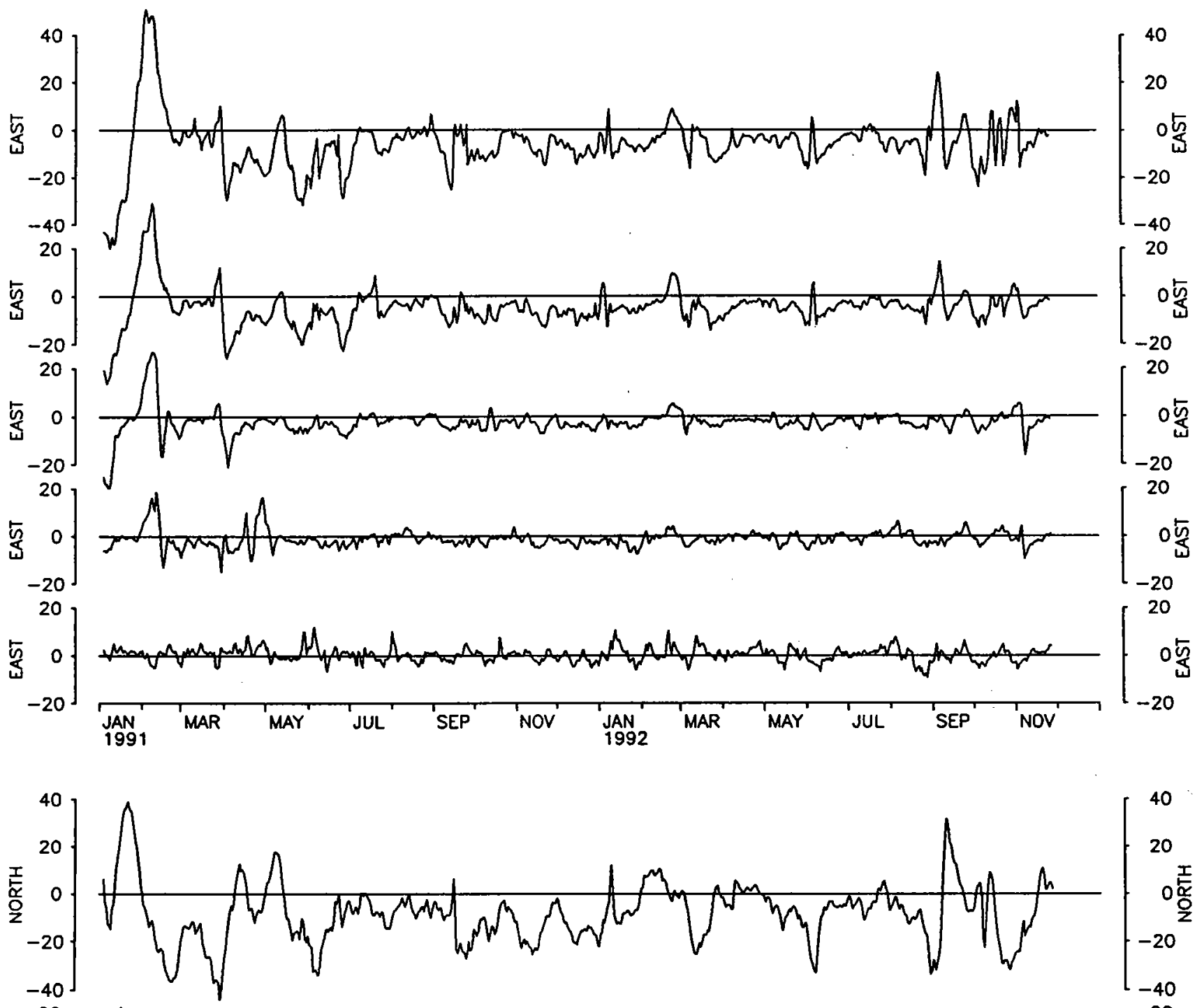

(20) 


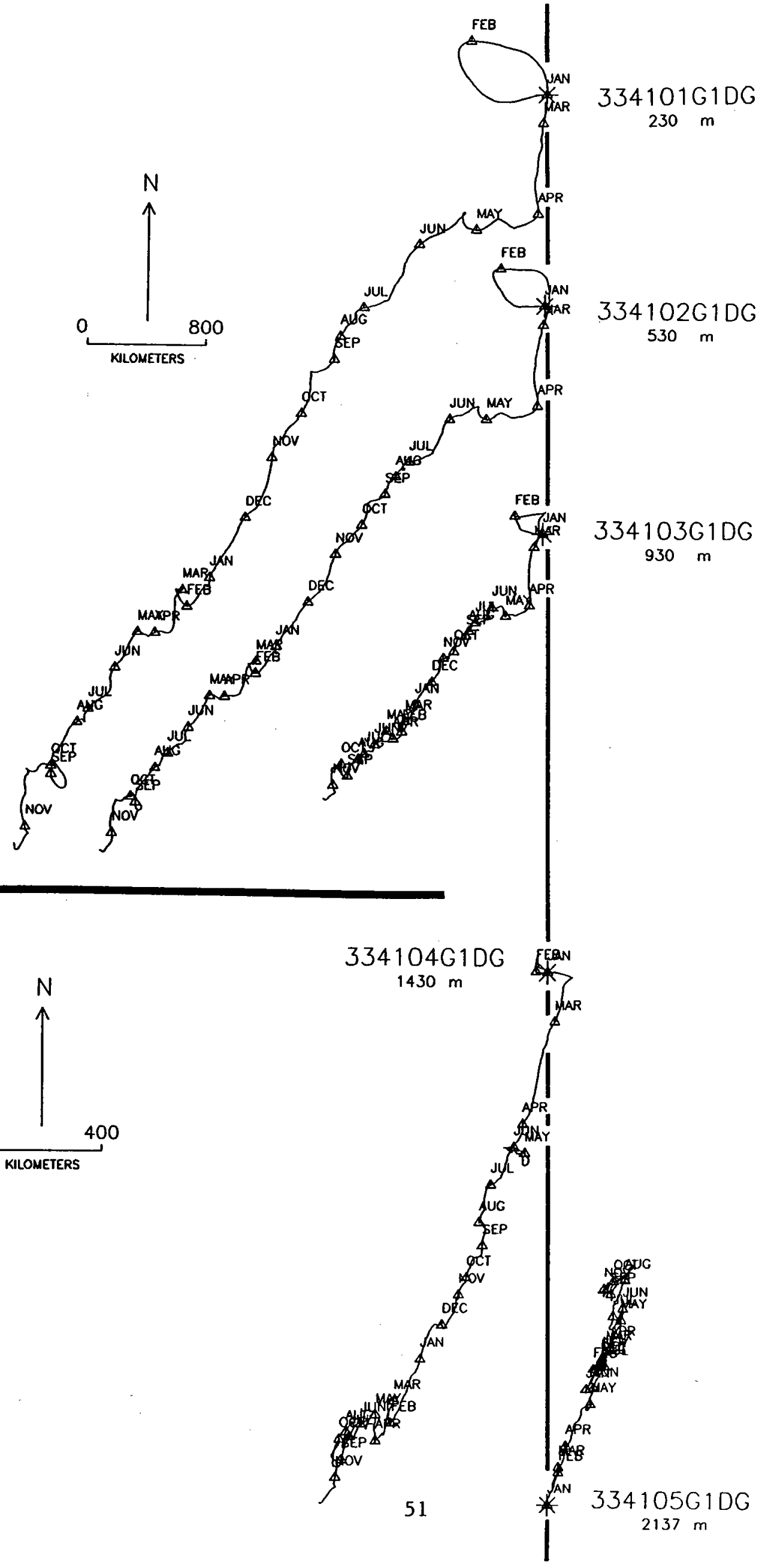




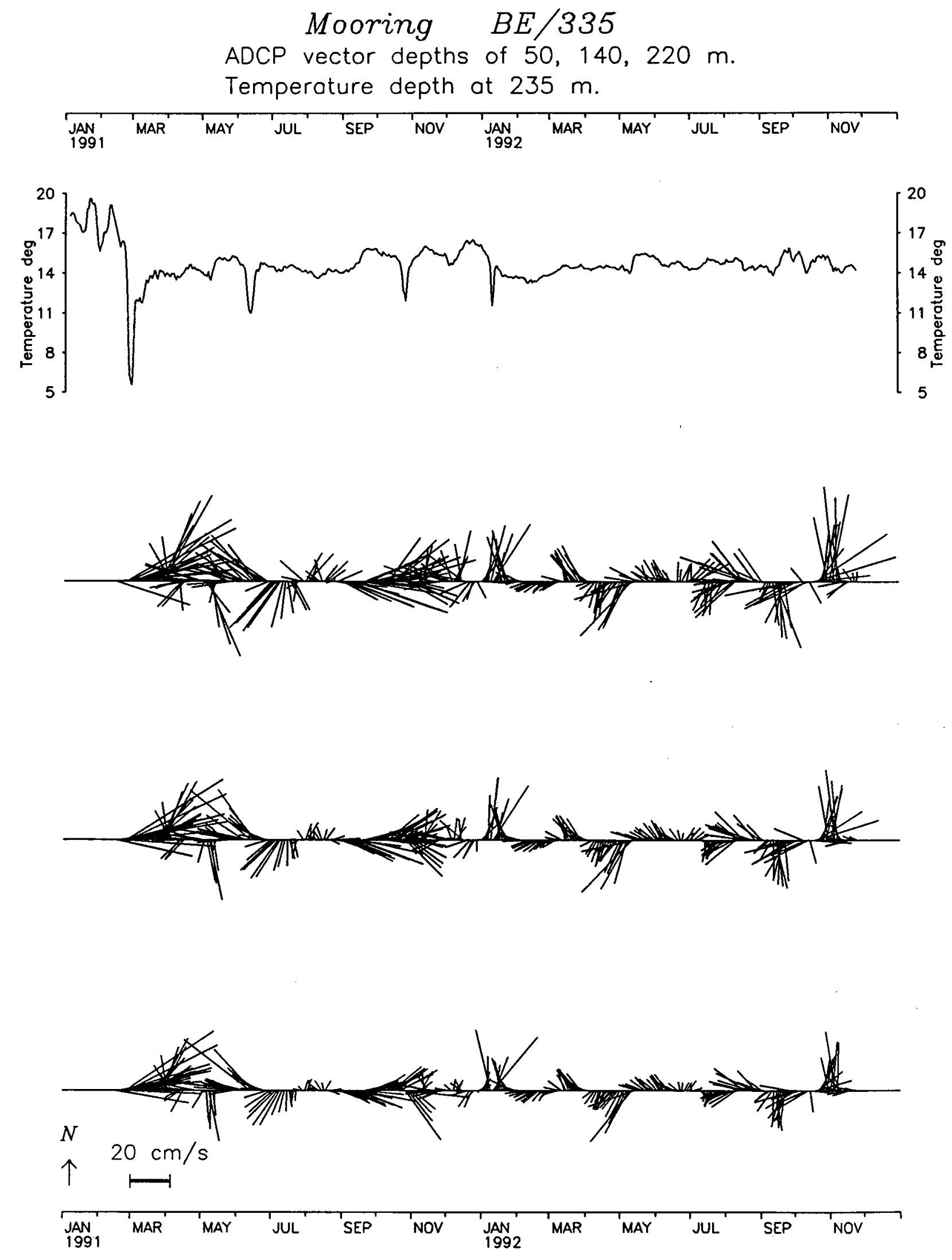


Mooring 335 * variables from an $A D C P$ instrument depth of $235 \mathrm{~m}$.

JAN
1991

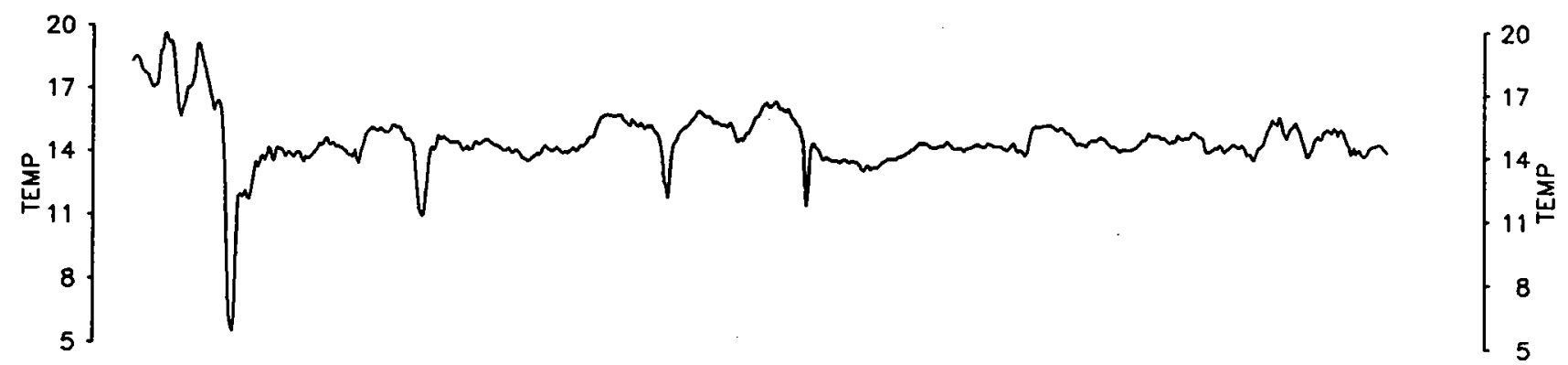

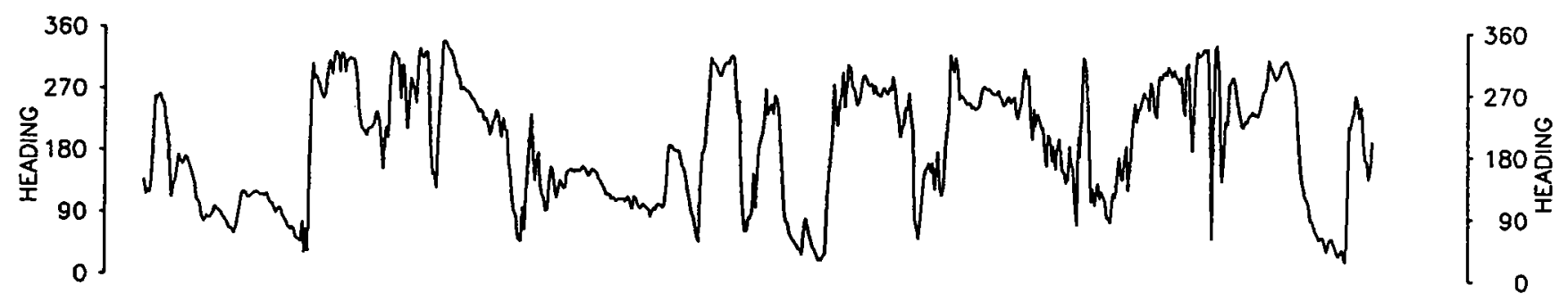

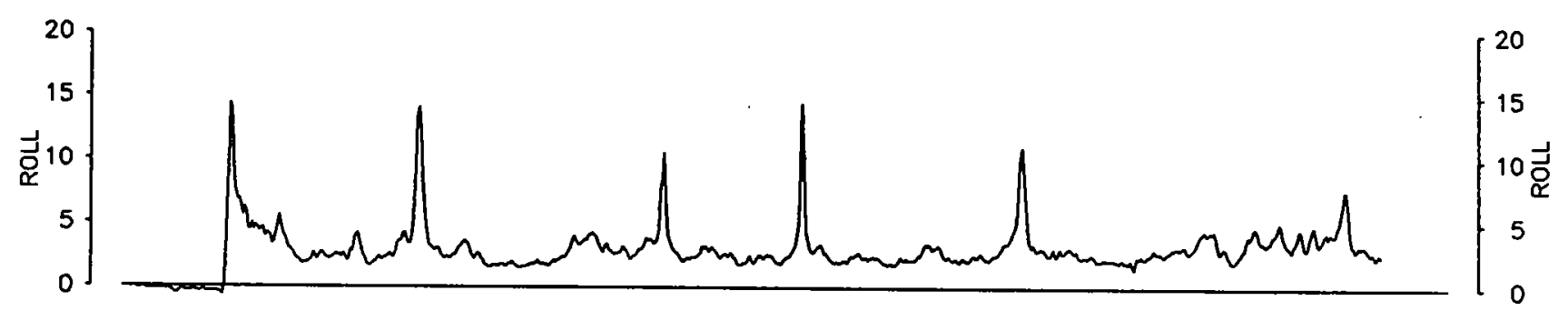

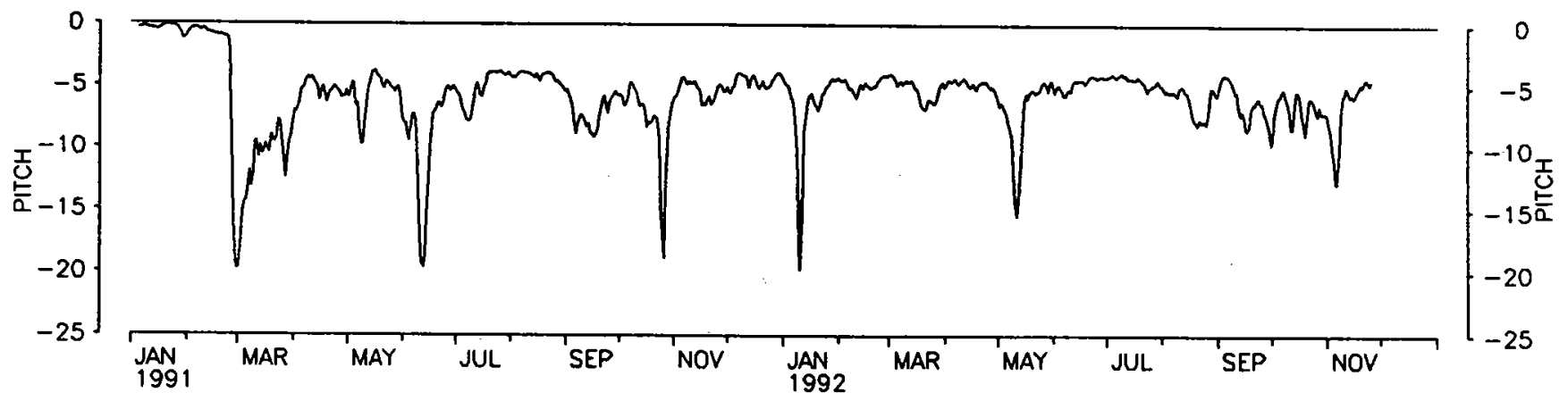


Mooring $335 * U$ and $V$ components from on ADCP depths of $50,140,220 \mathrm{~m}$.
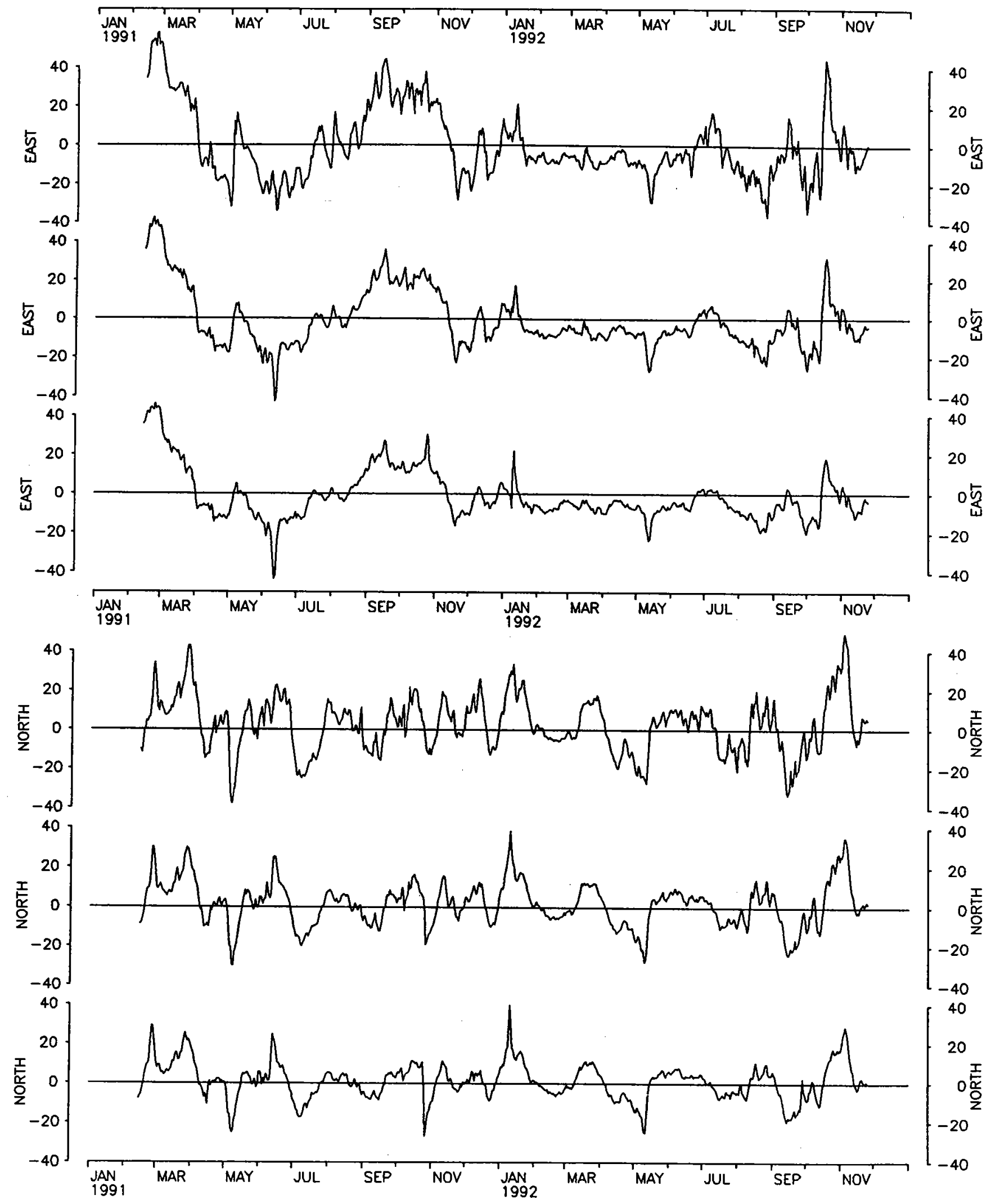

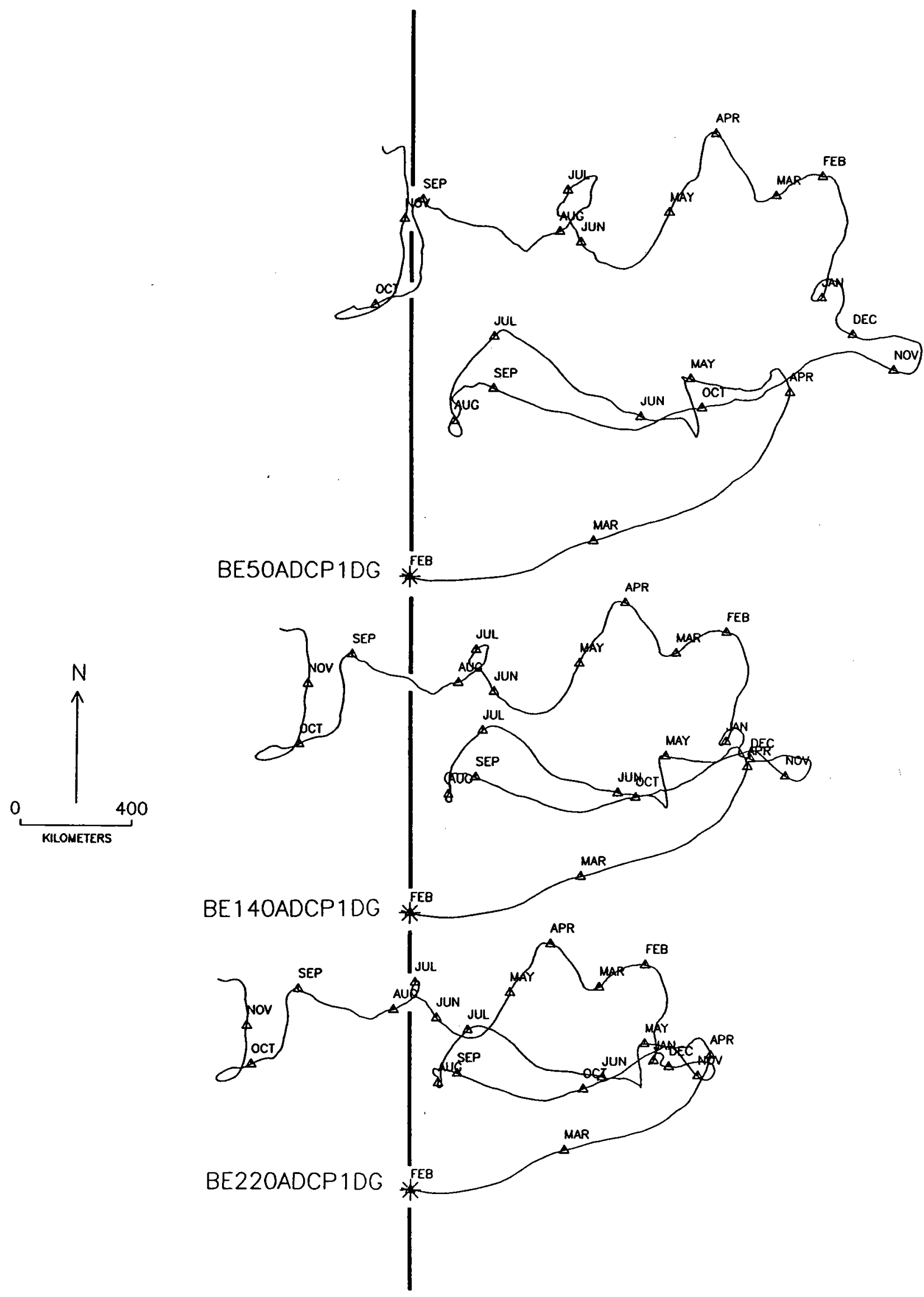
Mooring $335 * W$ and $E$ variables from an ADCP depths of $50,140,220 \mathrm{~m}$.

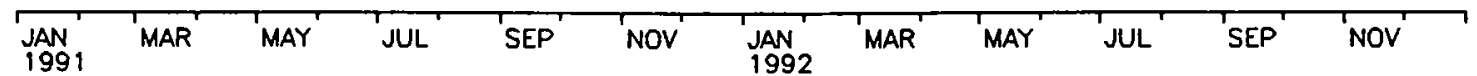

$\left.\begin{array}{cc} & 1.0 \\ & 0.5 \\ \frac{7}{0} & \\ \frac{0}{0} & 0.0 \\ \frac{2}{0} & -0.5 \\ \frac{0}{0} & \\ & -1.0\end{array}\right]$

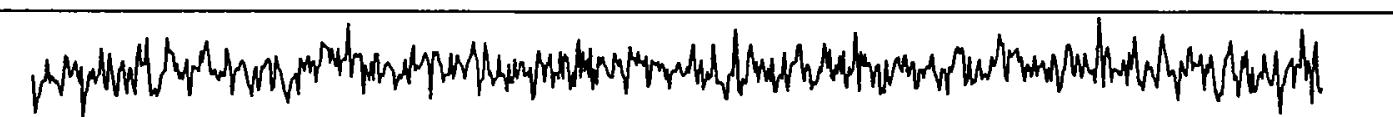

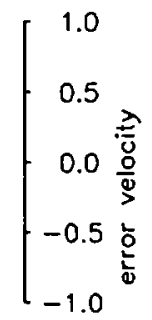

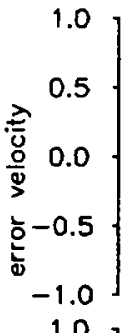

(1)

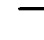

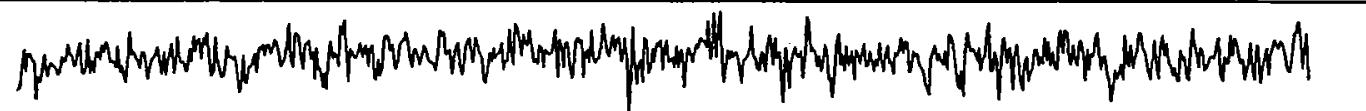

1.0

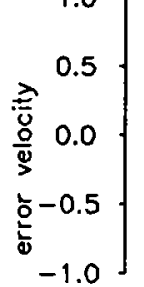

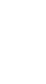

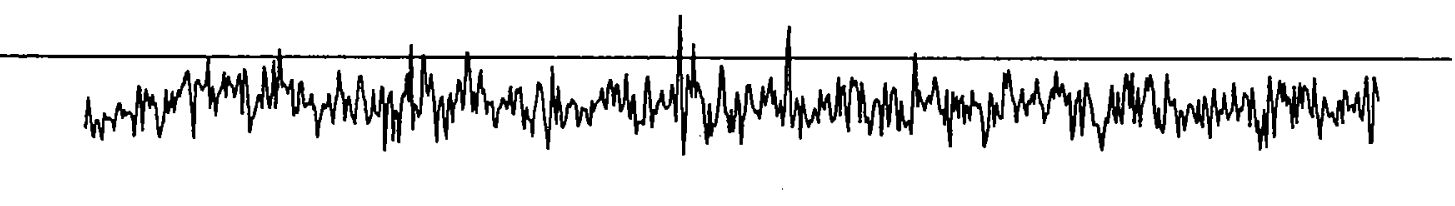

0.5

$0.0 ?$

-0.5 通

$-1.0$

$\left[\begin{array}{c}1.0 \\ 0.5 \\ 0.0 \\ -0.5 \frac{0}{9} \\ -1.0\end{array}\right.$

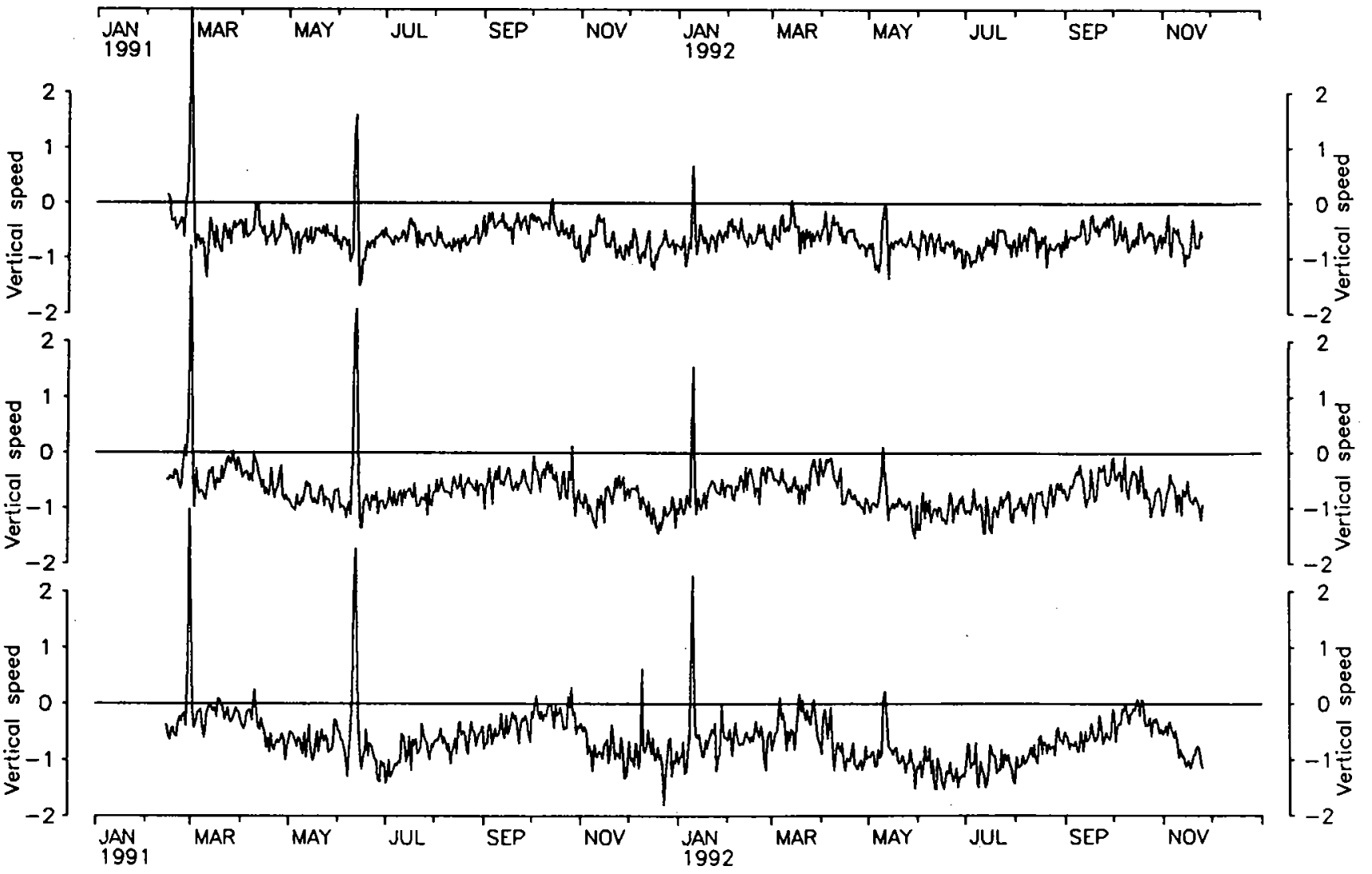




\section{THIS PAGE BLANK}



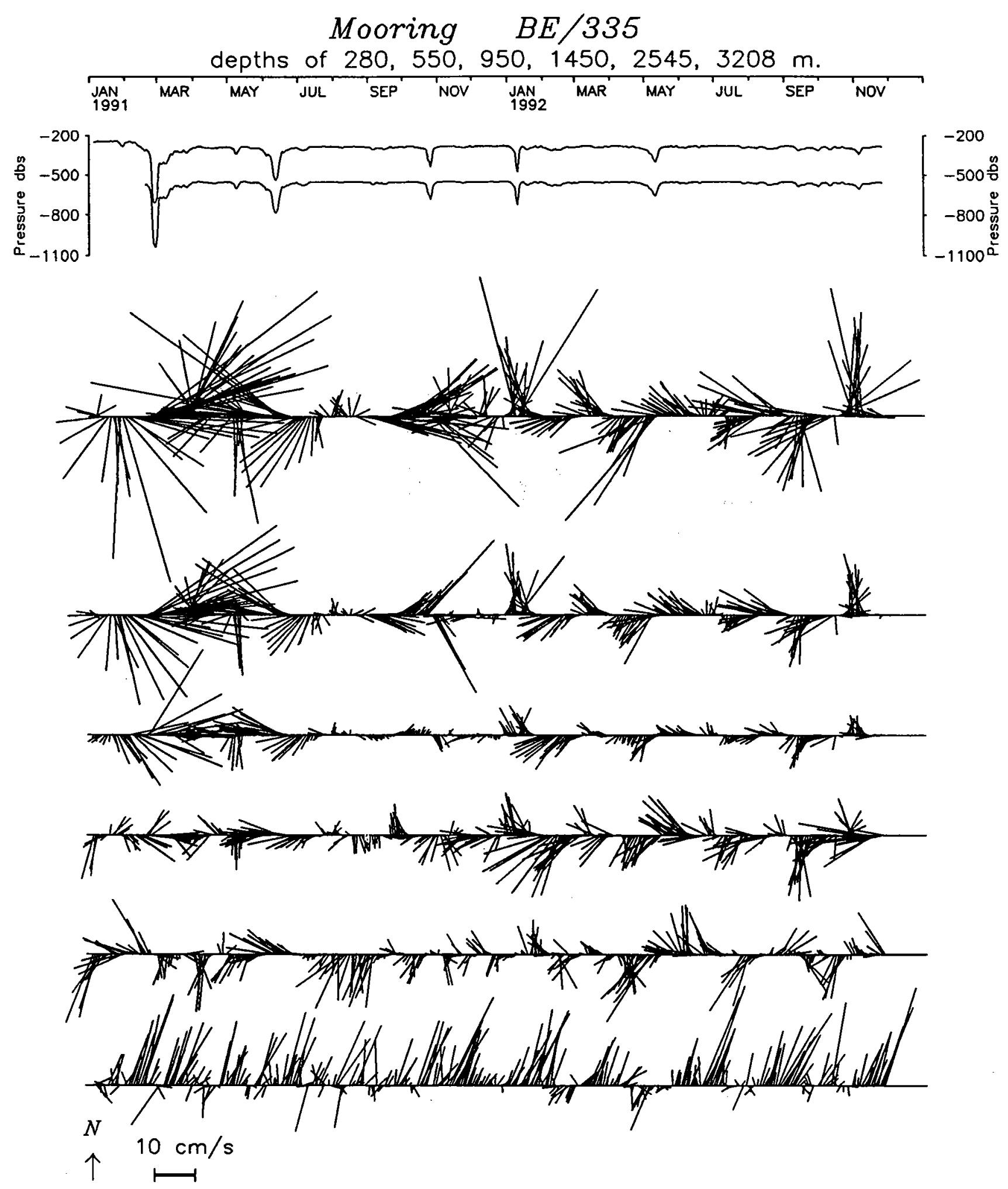

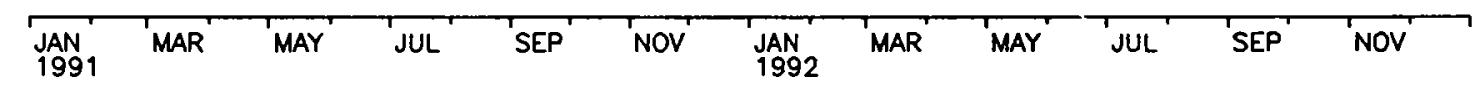


Mooring $\mathrm{BE} / 335$

* Temperatures at 280,550, 950, 1450, 2545, 3208 meters

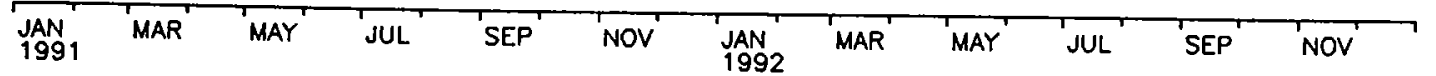
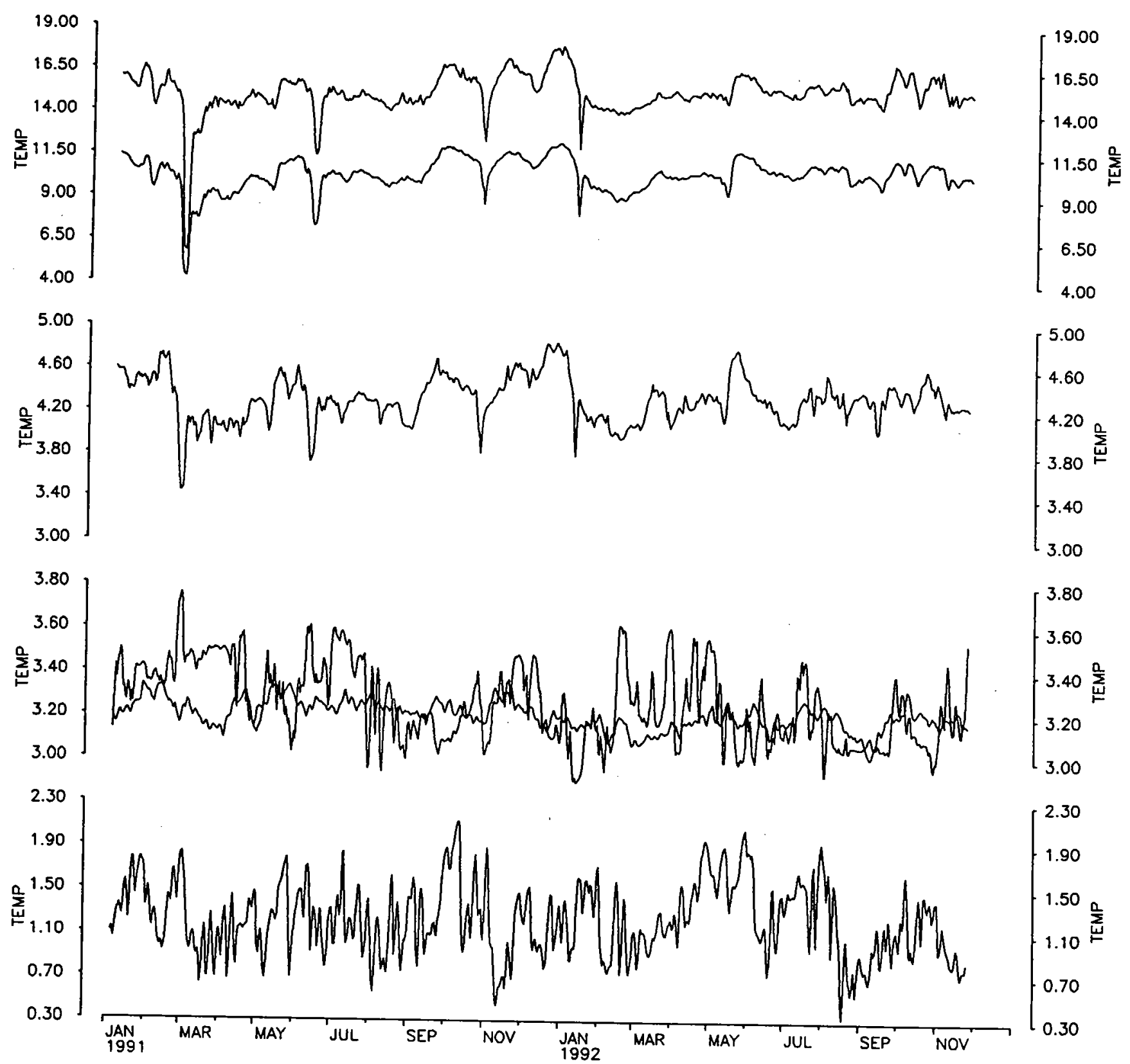


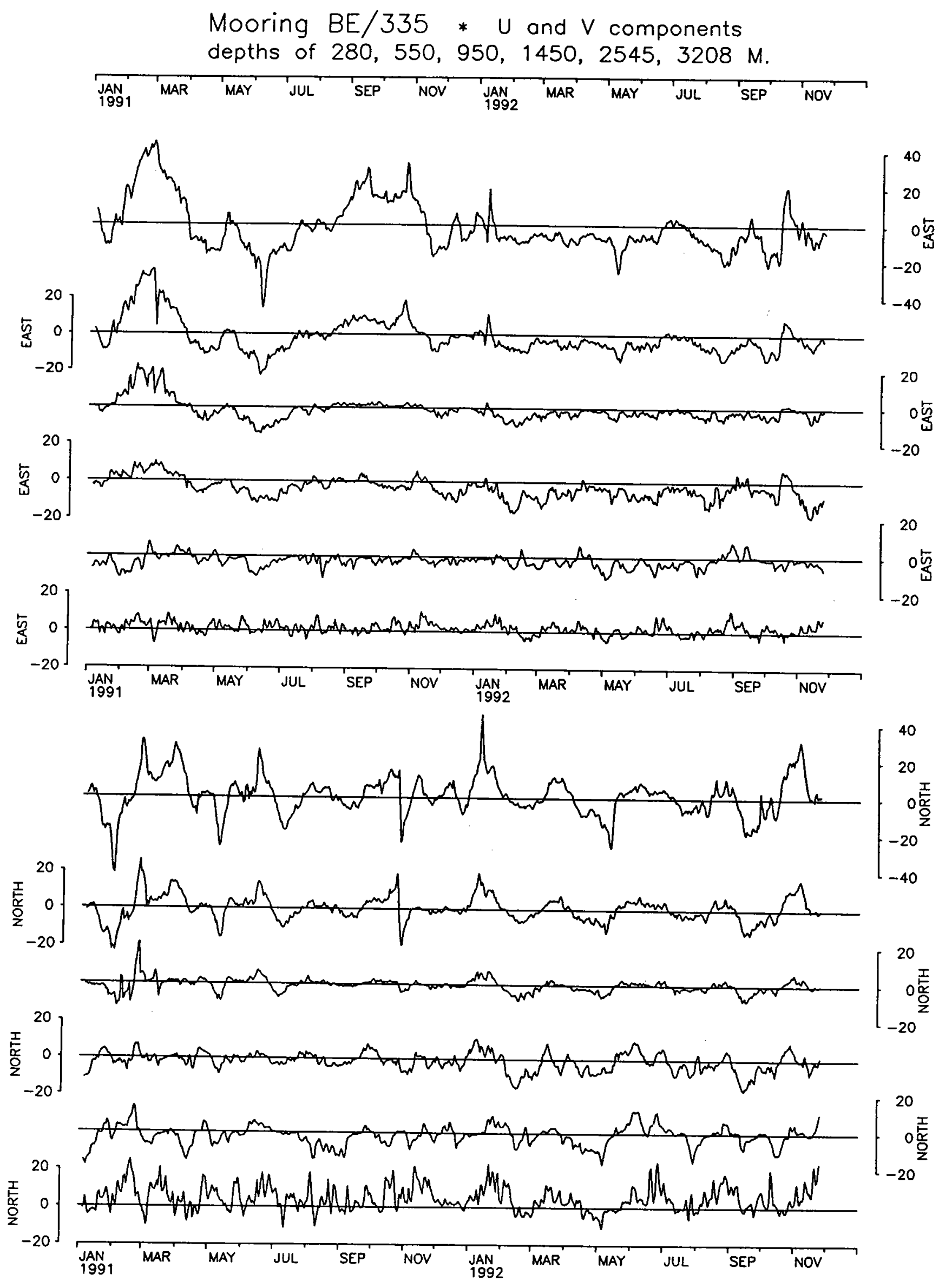




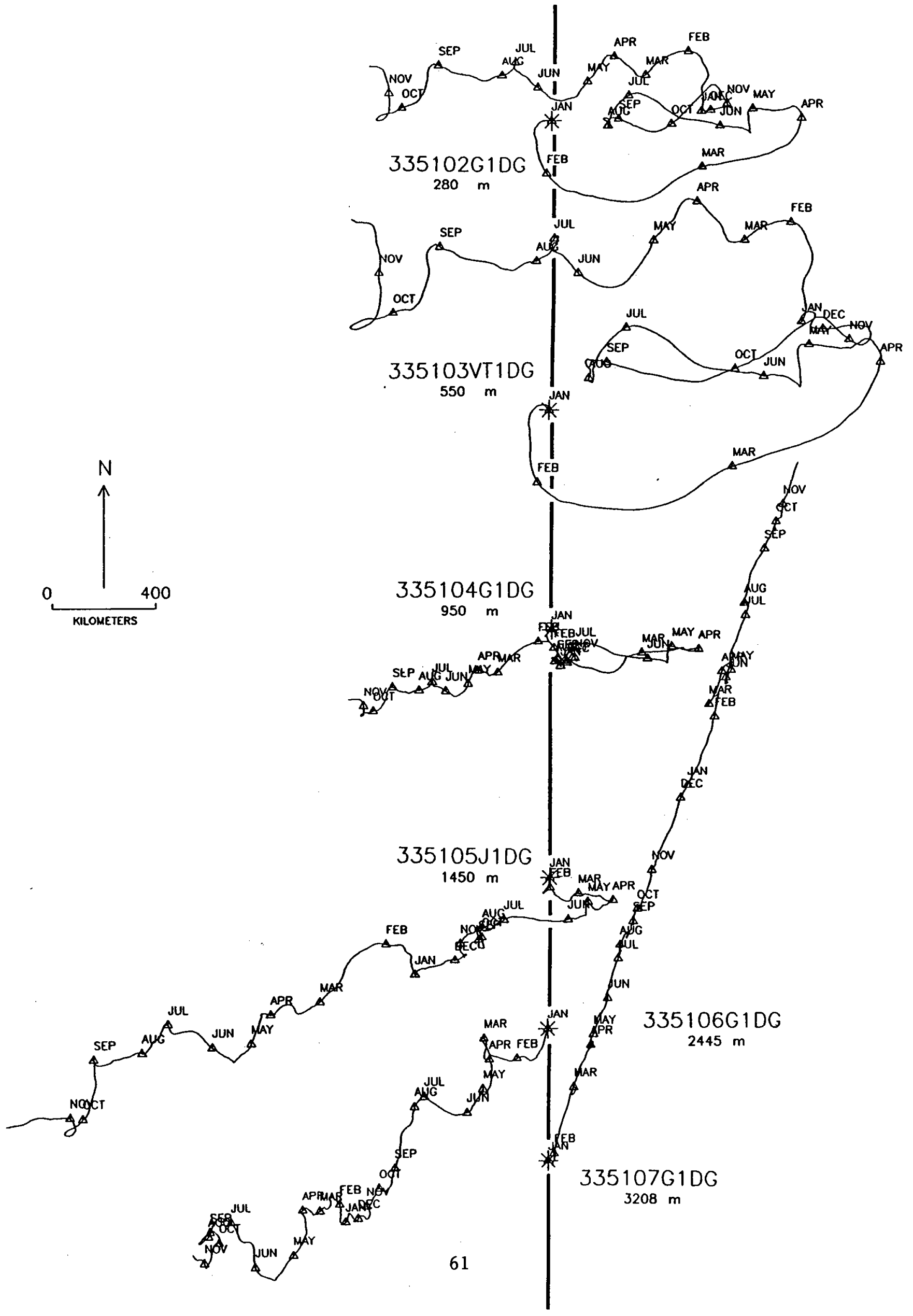


Mooring $D B 1 / 906$

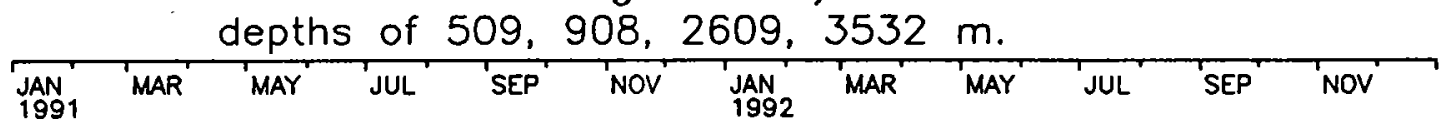
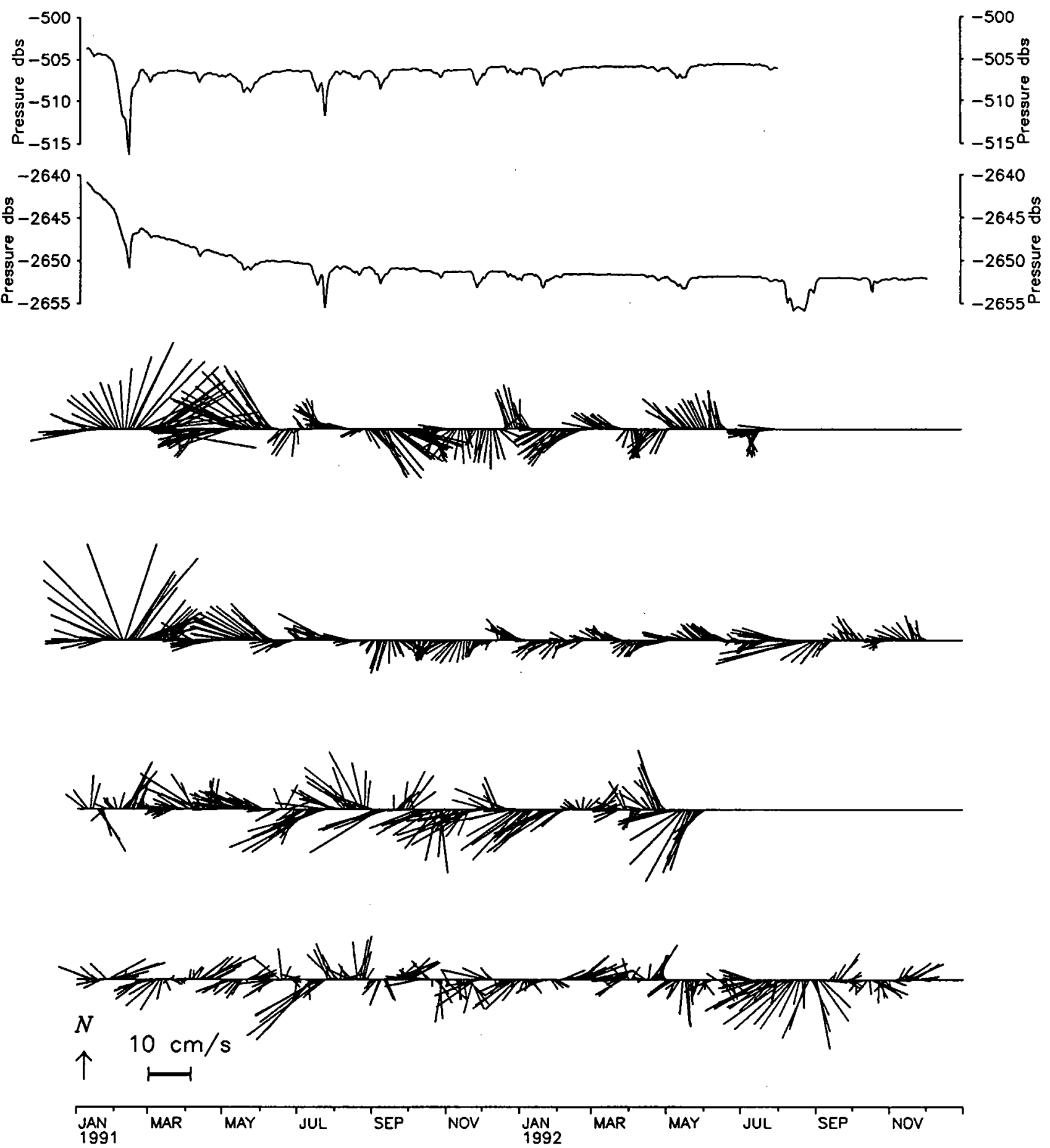
* Temperatures at 509, 908, 2609, $3532 \mathrm{M}$.

JAN' MAR MAY 'JUL' SEP NOV JAN 'MAR MAY JUL' SEP NOV' :
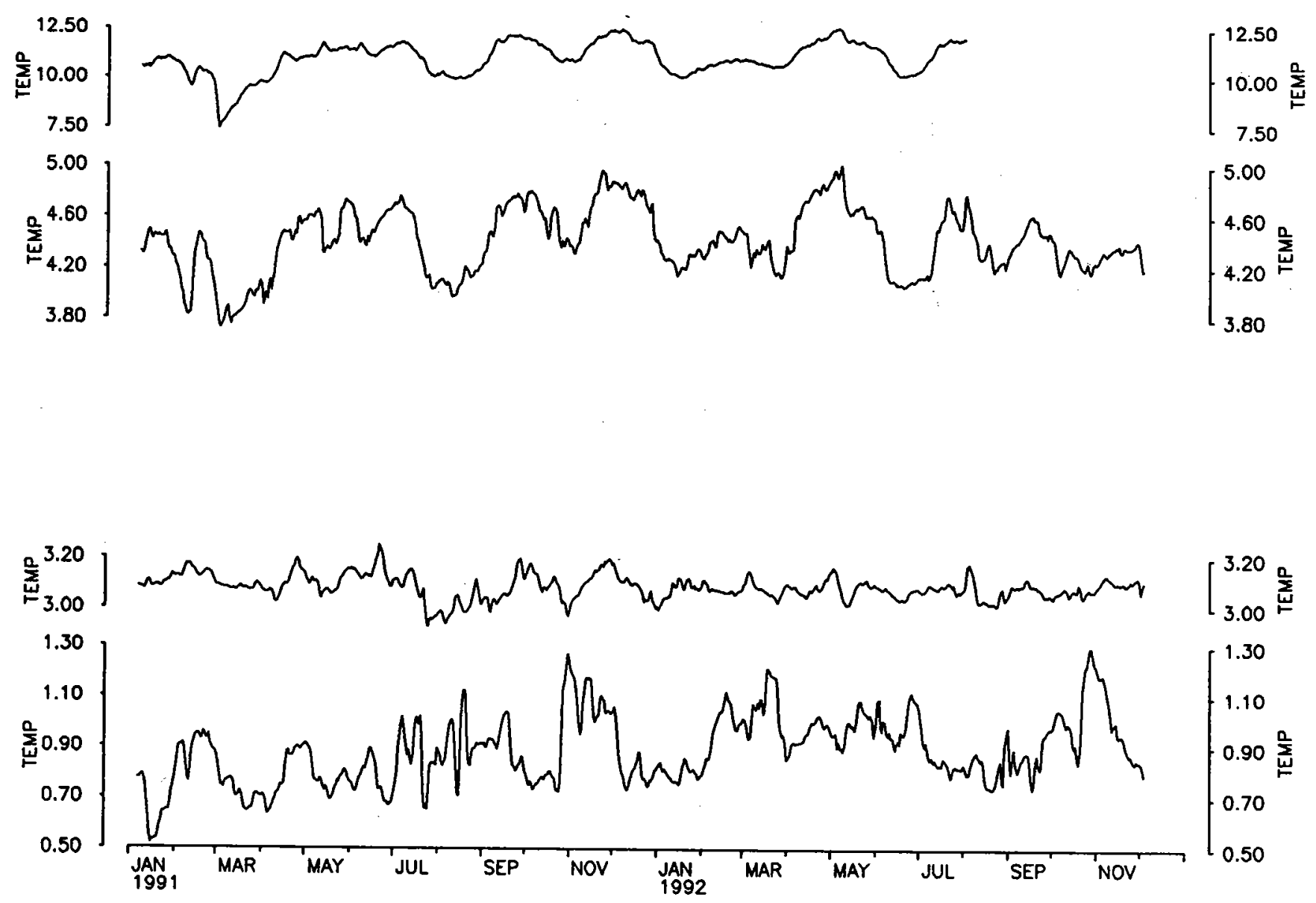


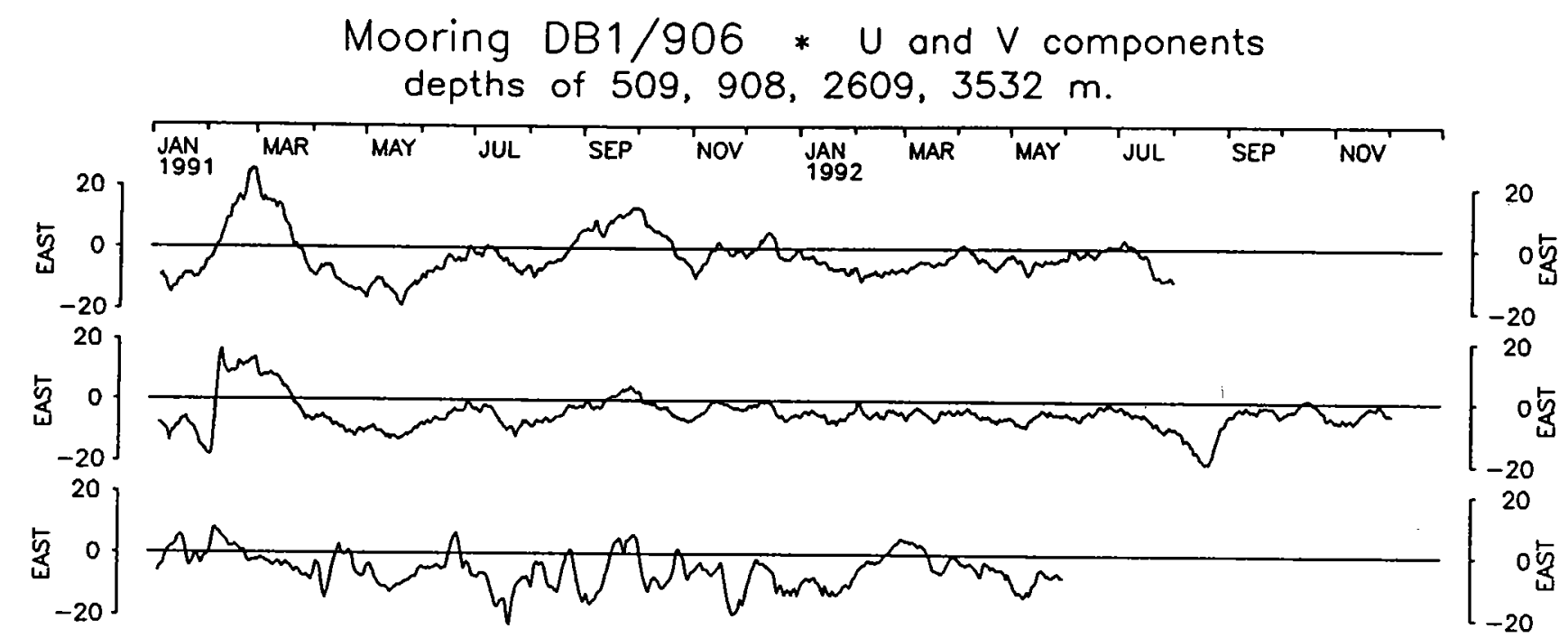

S20
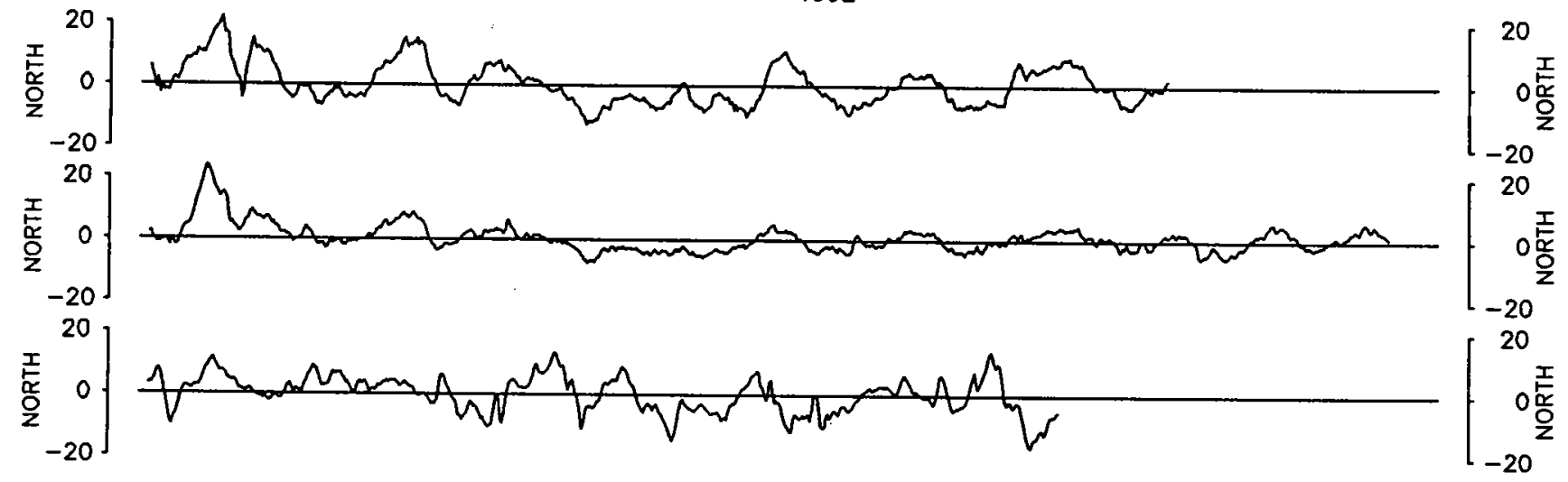

$\sum_{-20}^{20} \underbrace{20}_{\substack{\text { JAN } \\ \text { I991 }}}$ 


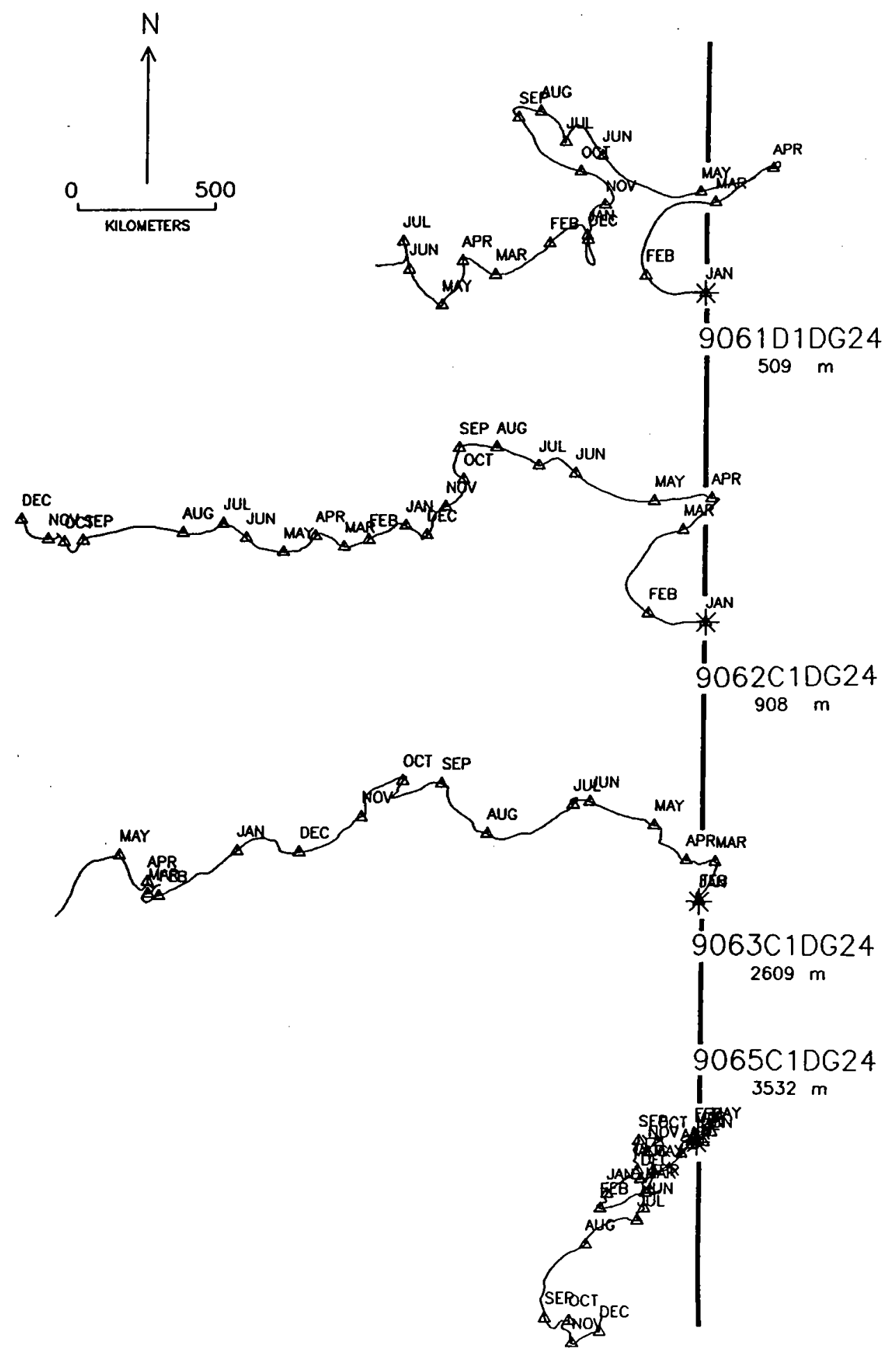


Mooring $D B 2 / 907$

depths of $496,895,2595,2995,3850 \mathrm{~m}$.
$\begin{aligned} & \text { JAN } \\ & \text { I991 }\end{aligned}$ MAR $_{\text {MAY }}$ JUL
SEP
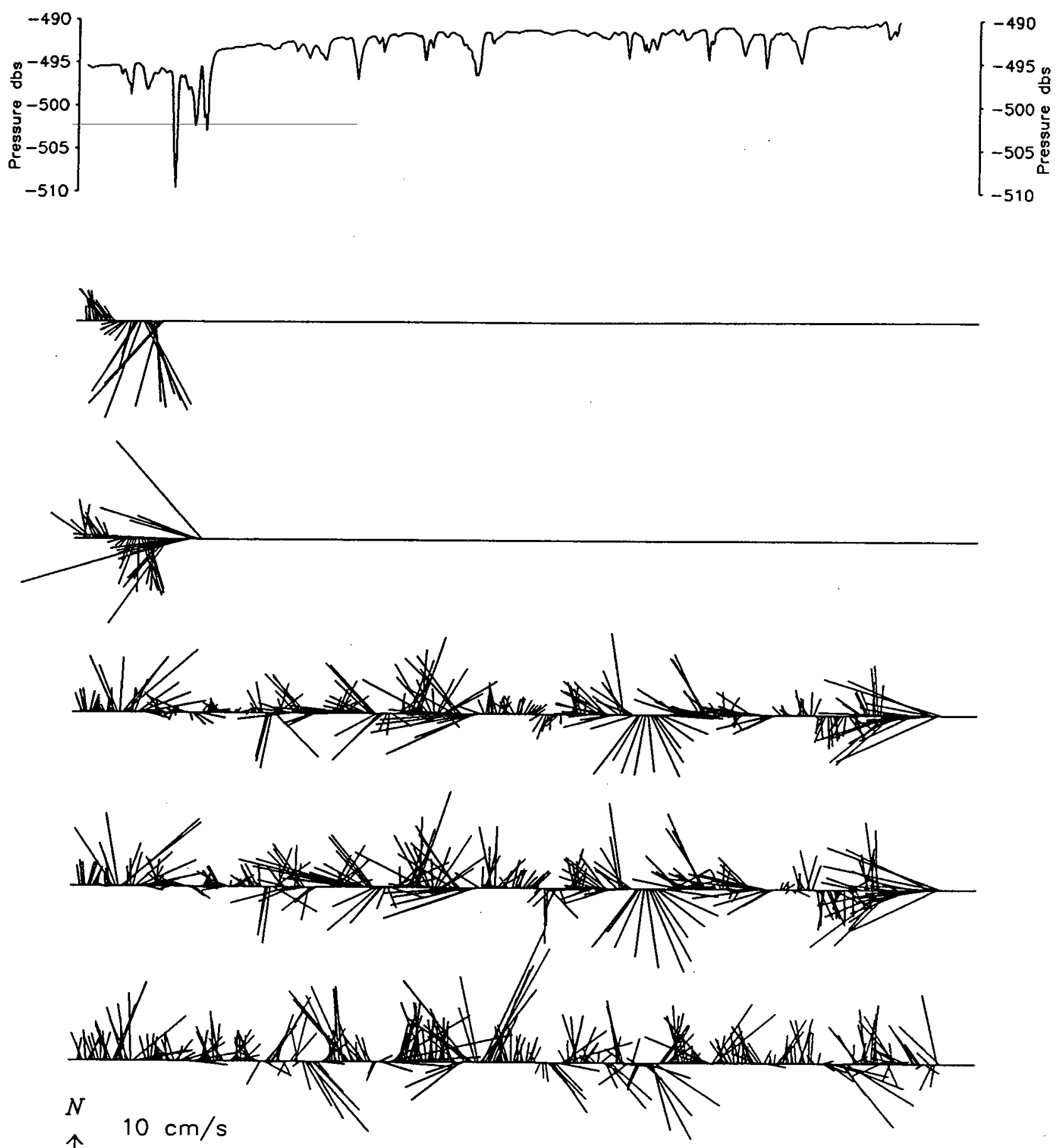

$\uparrow \quad 10 \mathrm{~cm} / \mathrm{s}$

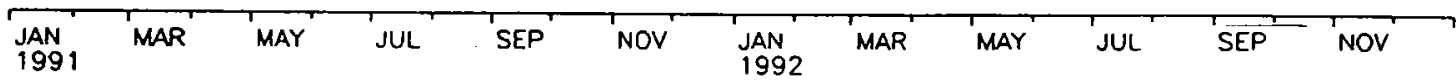


Mooring DB2/907

* Temperatures at 496, 895, 2595, 2995, $3850 \mathrm{M}$.

JAN MAR MAY JUL SEP NOV JAN
1991

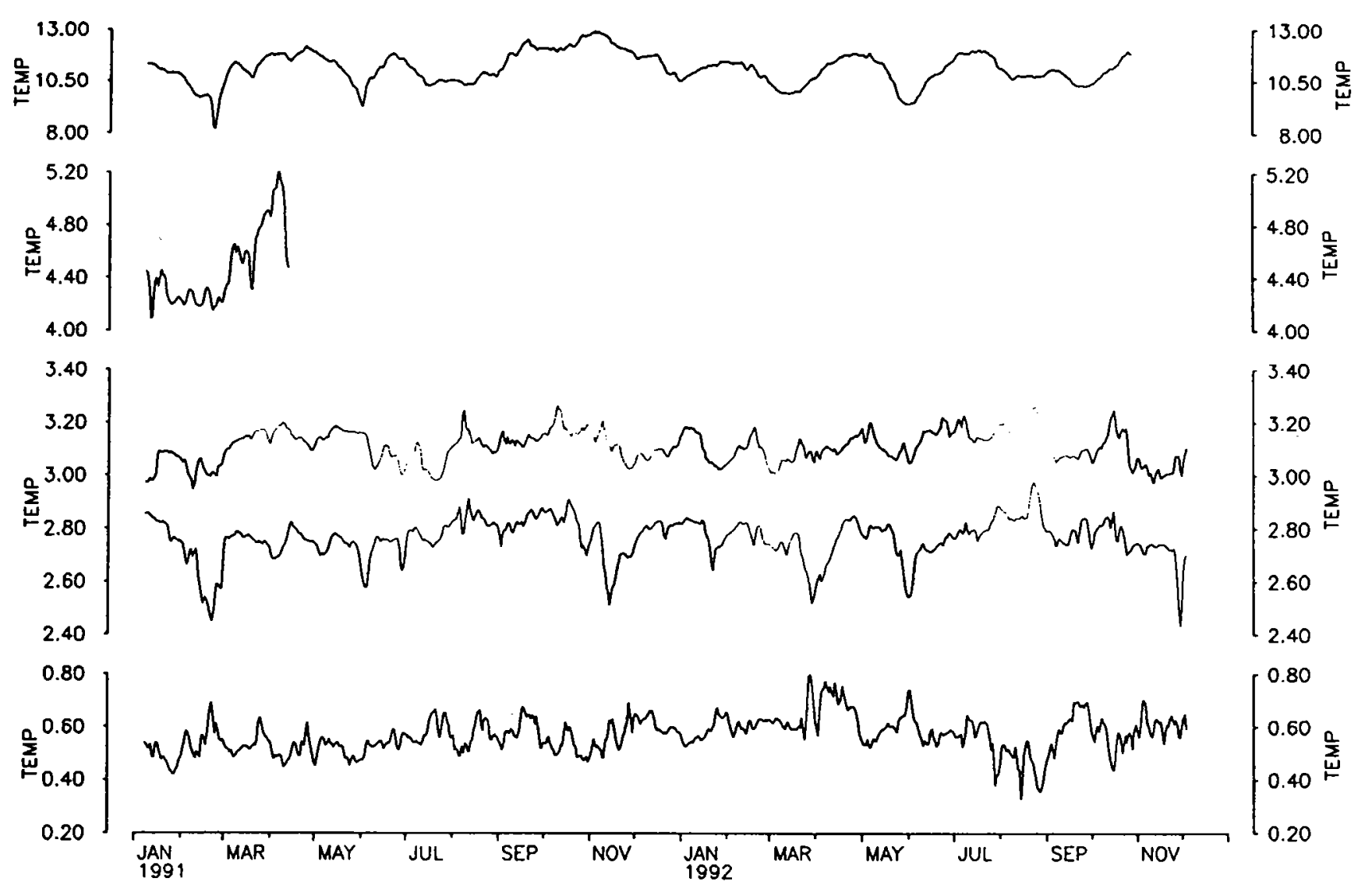


Mooring DB2/907* $U$ and $V$ components

depths of $496,895,2595,2995,3850 \mathrm{M}$.

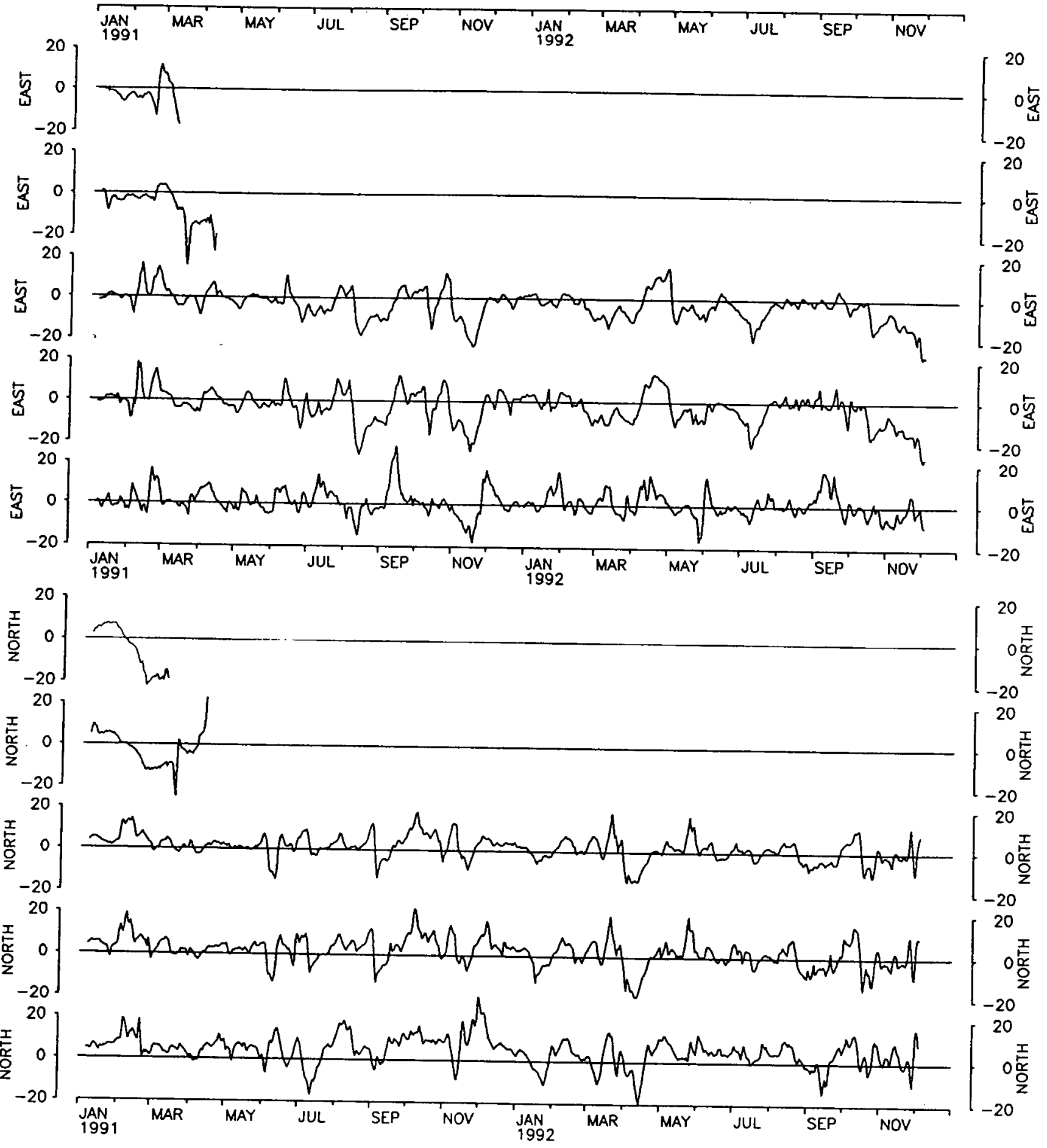




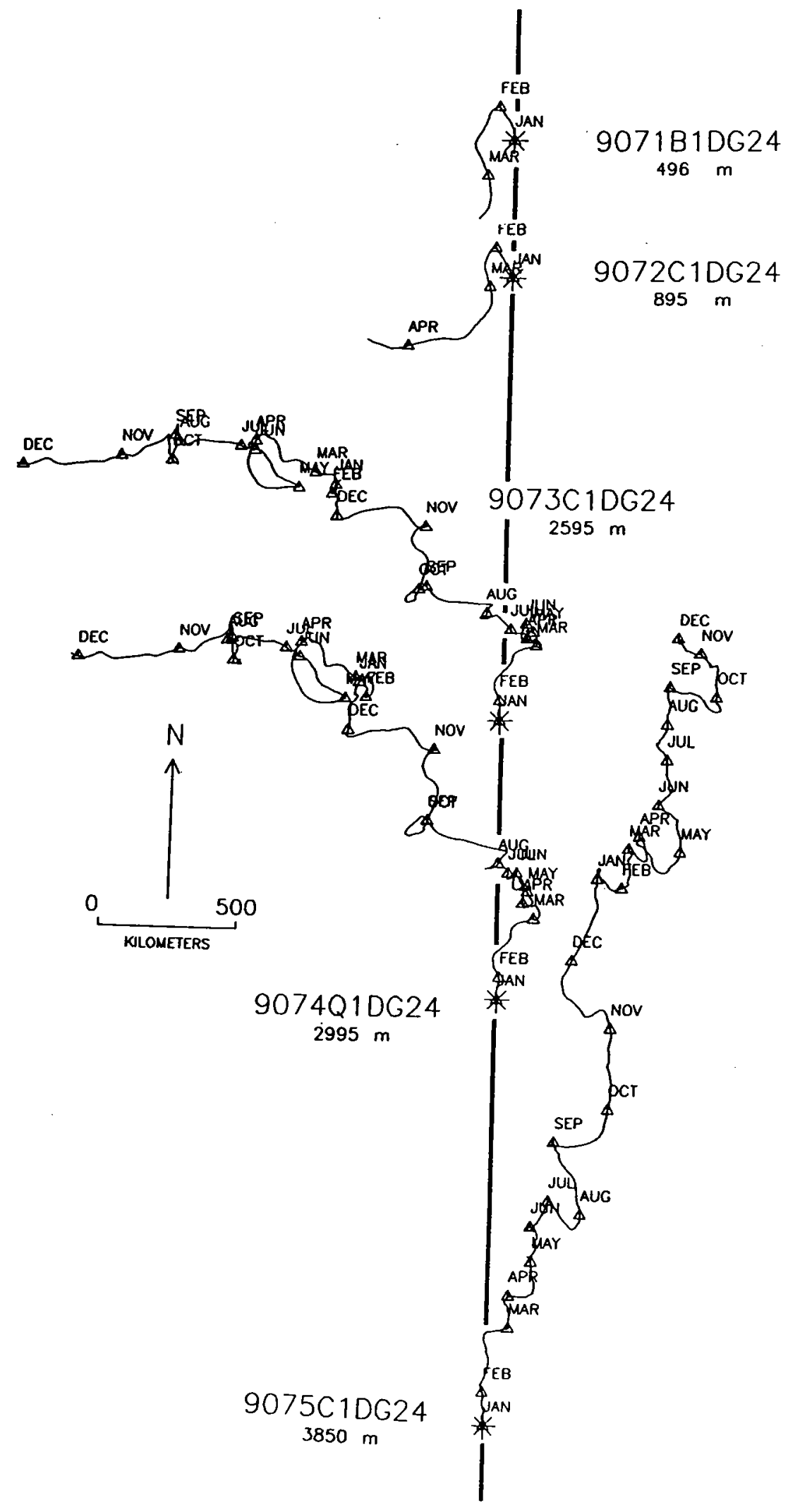




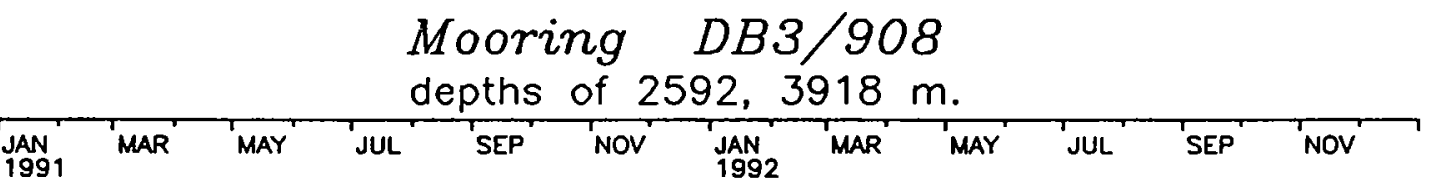
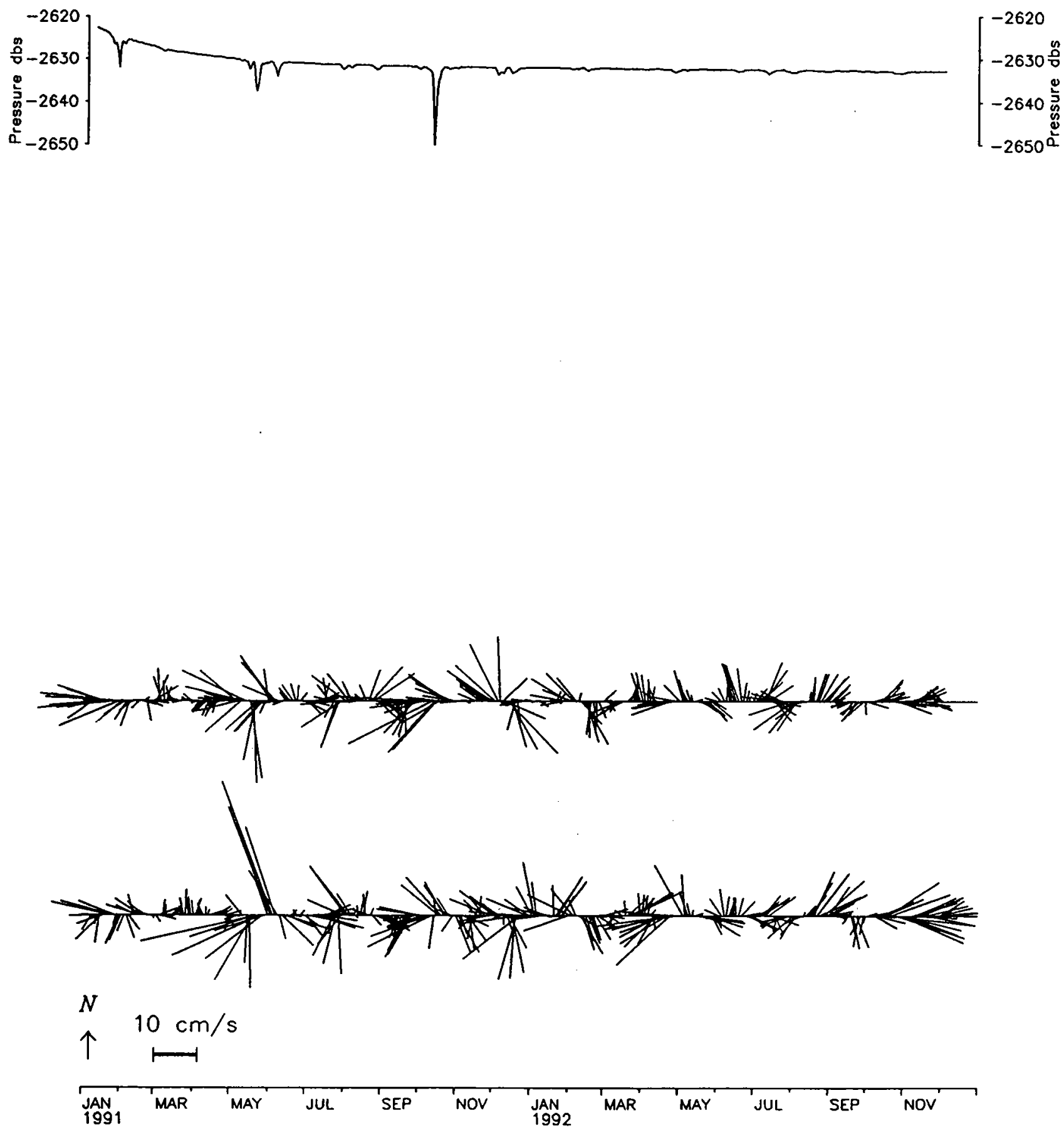
Mooring DB3/908

* Temperatures at 2592, $3918 \mathrm{~m}$.

JAN MAR MAY JUL SEP NOV JAN MAR MAY JUL 'SEP NOV

$\left.\sum_{3.00}^{\frac{a}{5}}\right]_{3.00}^{3.20}$

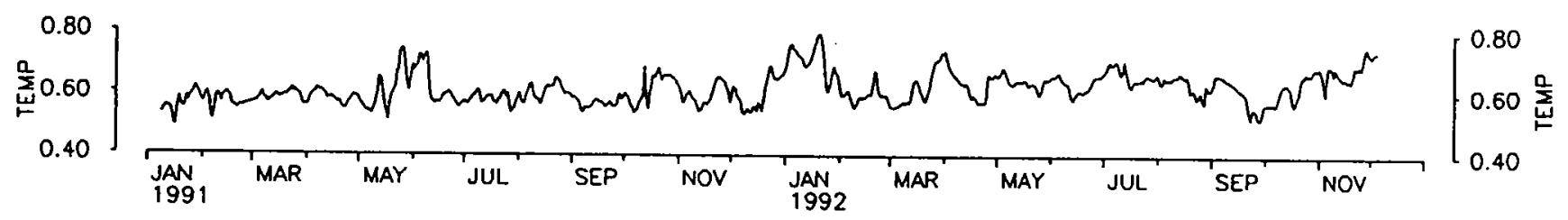




\section{Mooring DB3/908* $\mathrm{U}$ and $\mathrm{V}$ components}

depths of 2592, $3918 \mathrm{~m}$.

JAN' MAR MAY JUL 'SEP' NOV JAN MAR MAY 'JUL 'SEP' NOV'
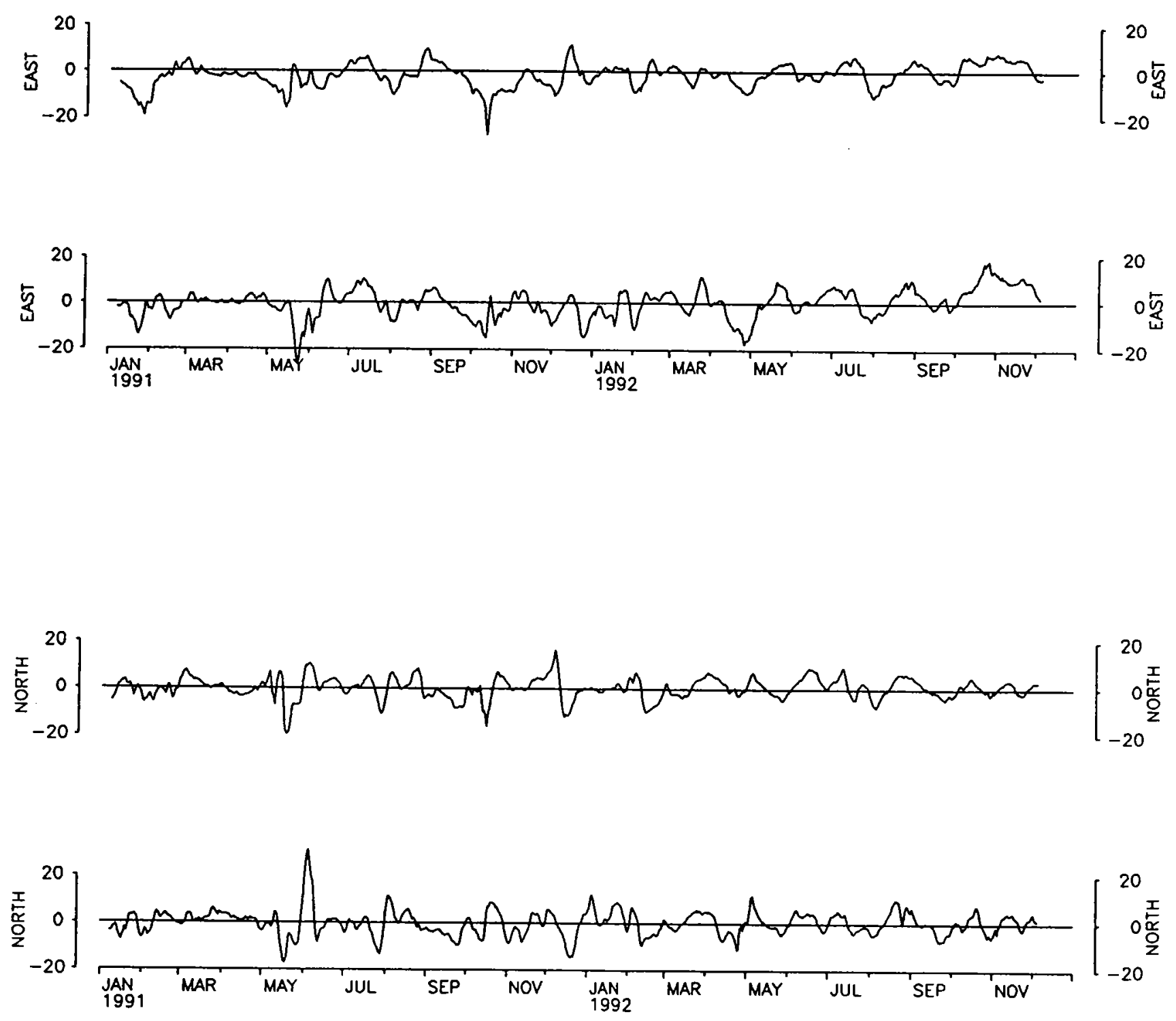


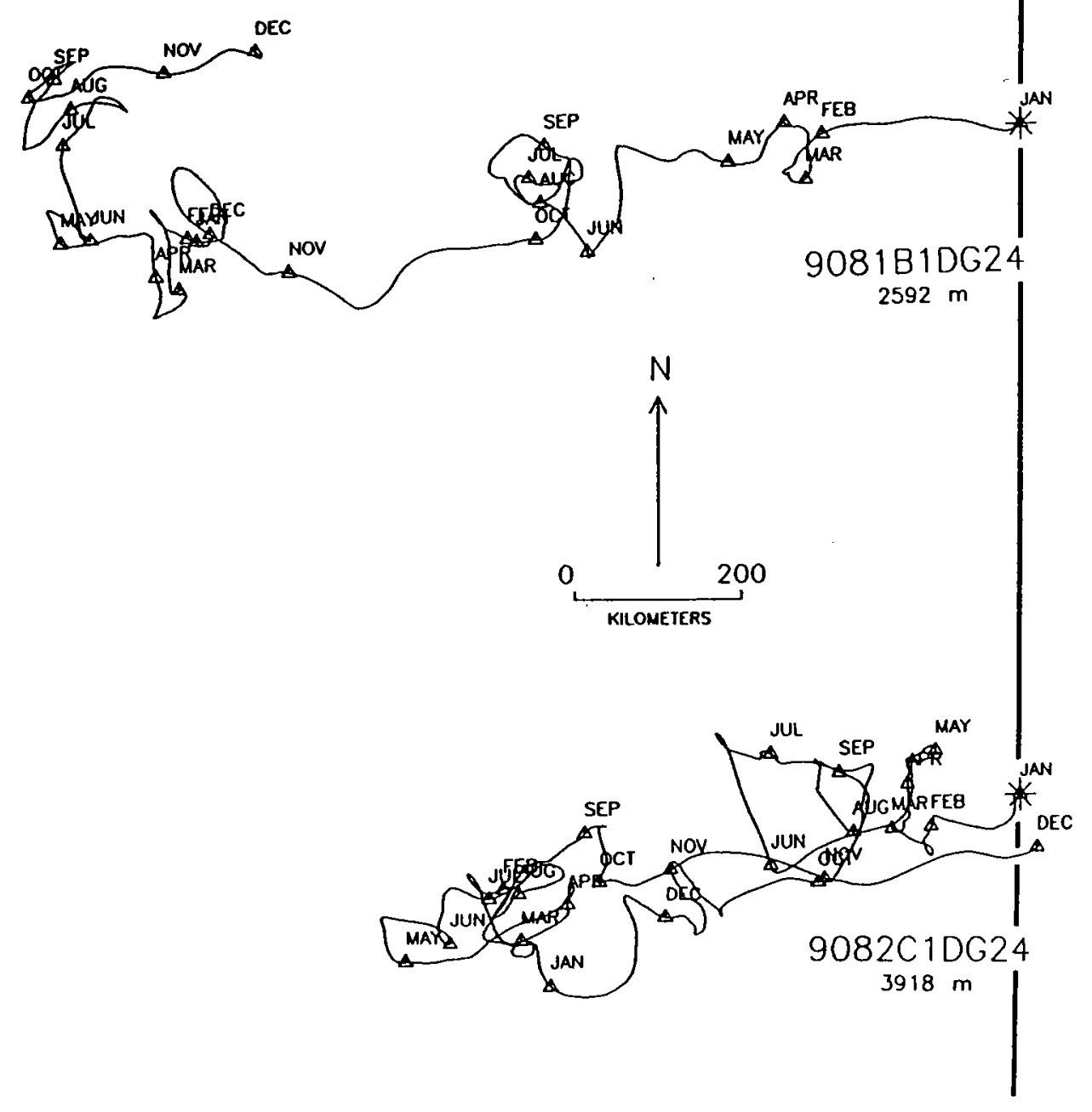



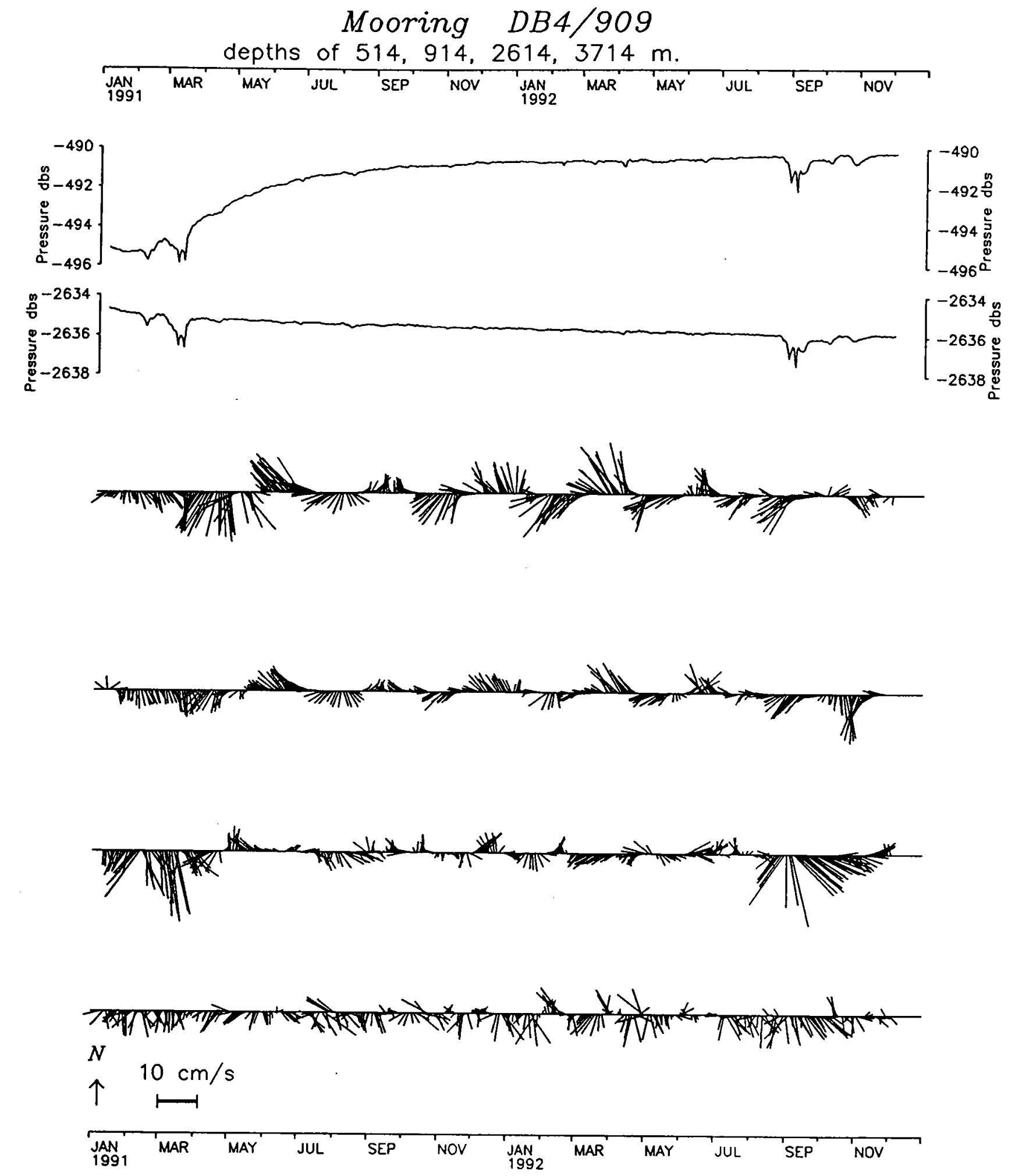
Mooring DB4/909

* Temperatures at $514,914,2614,3714 \mathrm{M}$.

JAN MAR MAY JUL SEP NOV JAN MAR MAY JUL 'SEP' NOV'
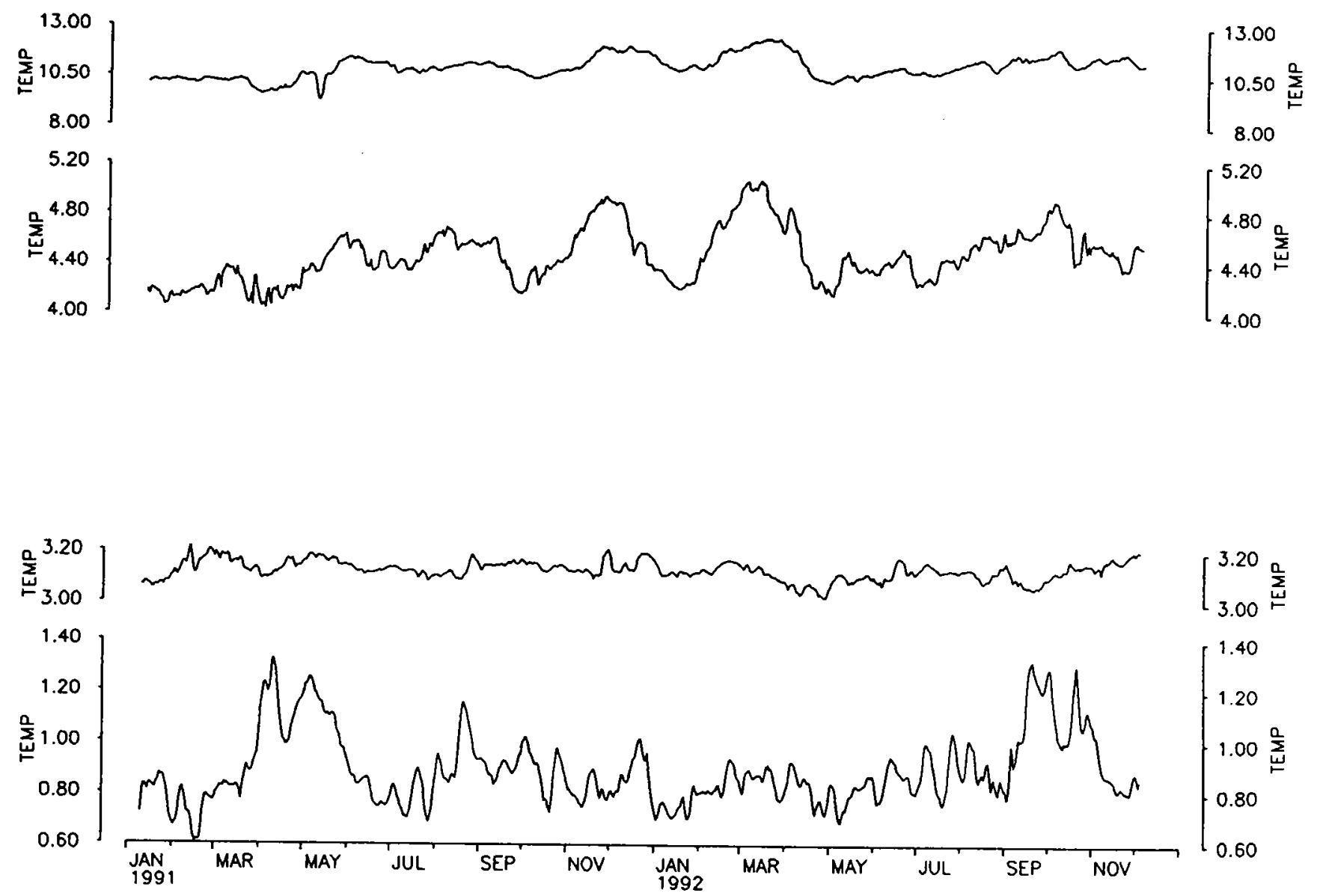
Mooring DB4/909* $U$ and $V$ components depths of $514,914,2614,3714 \mathrm{~m}$.
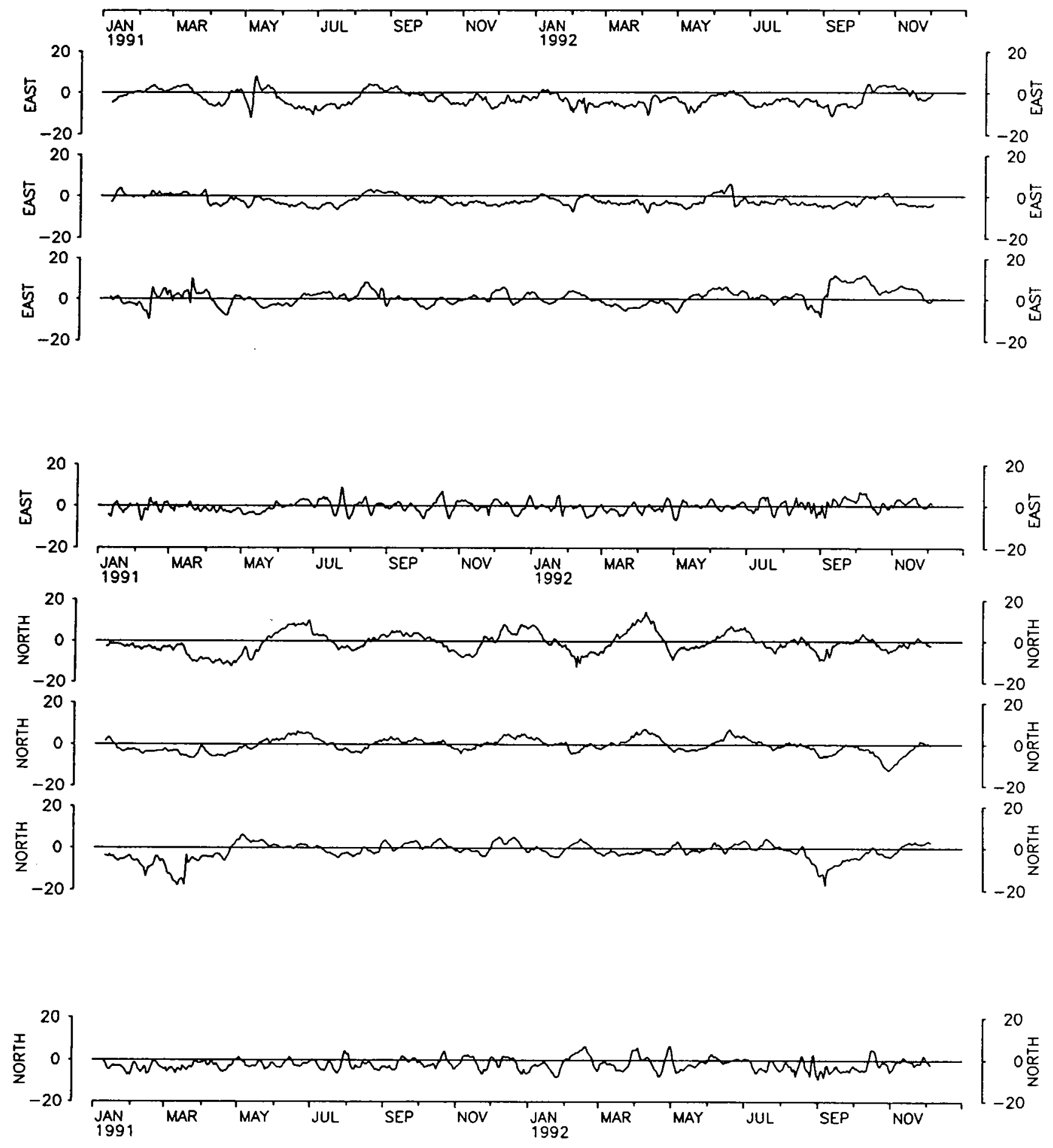


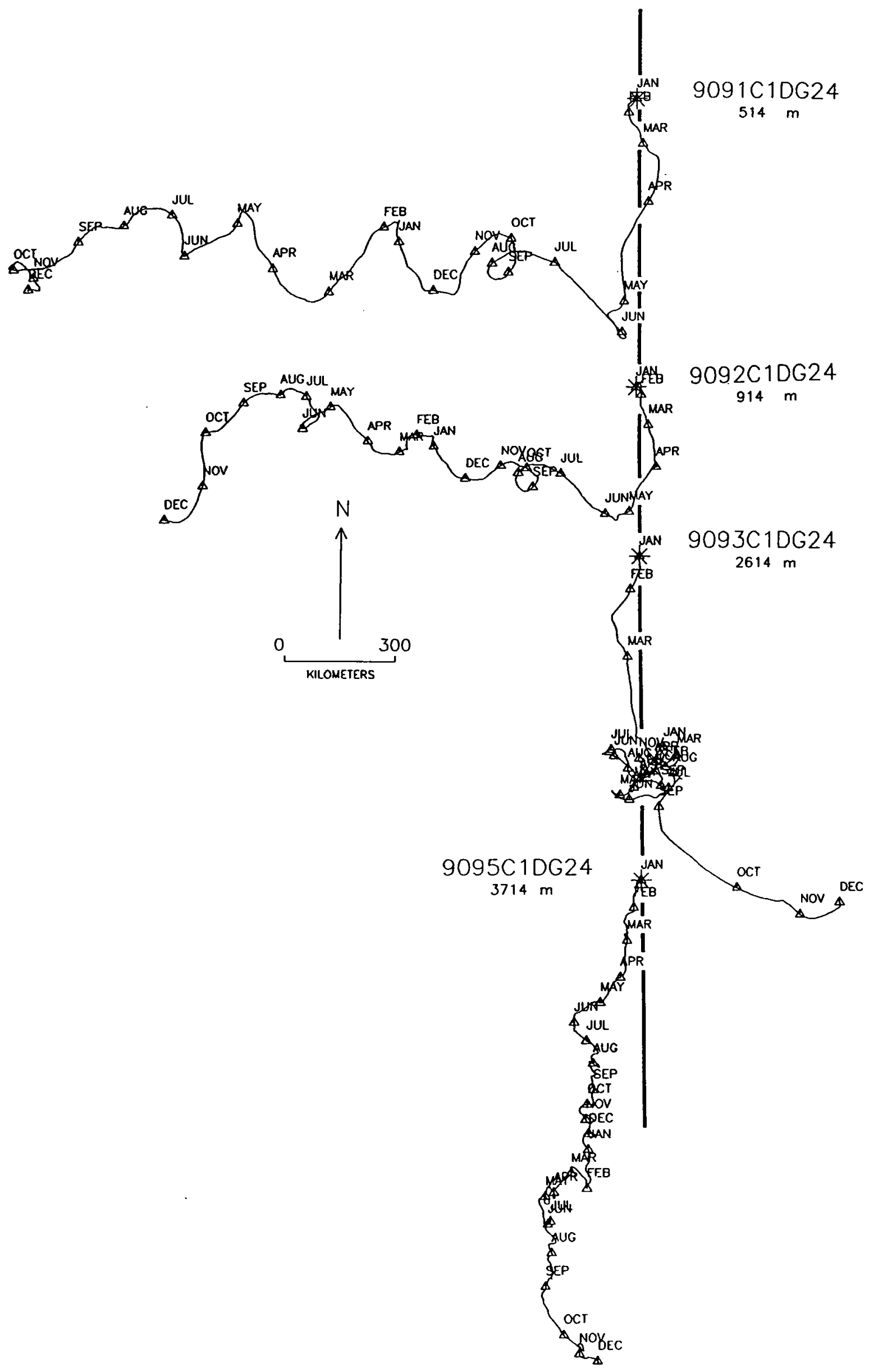



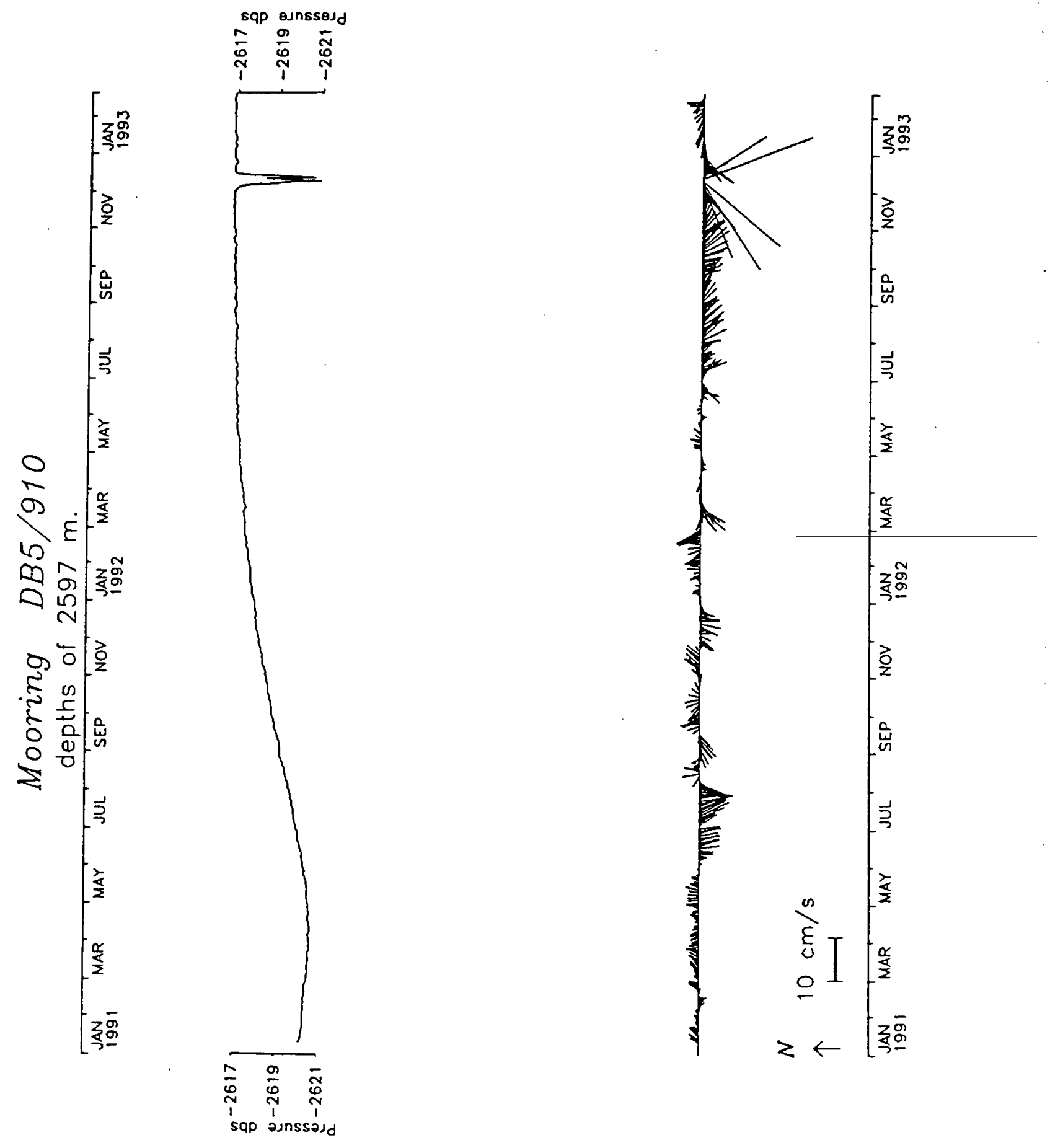


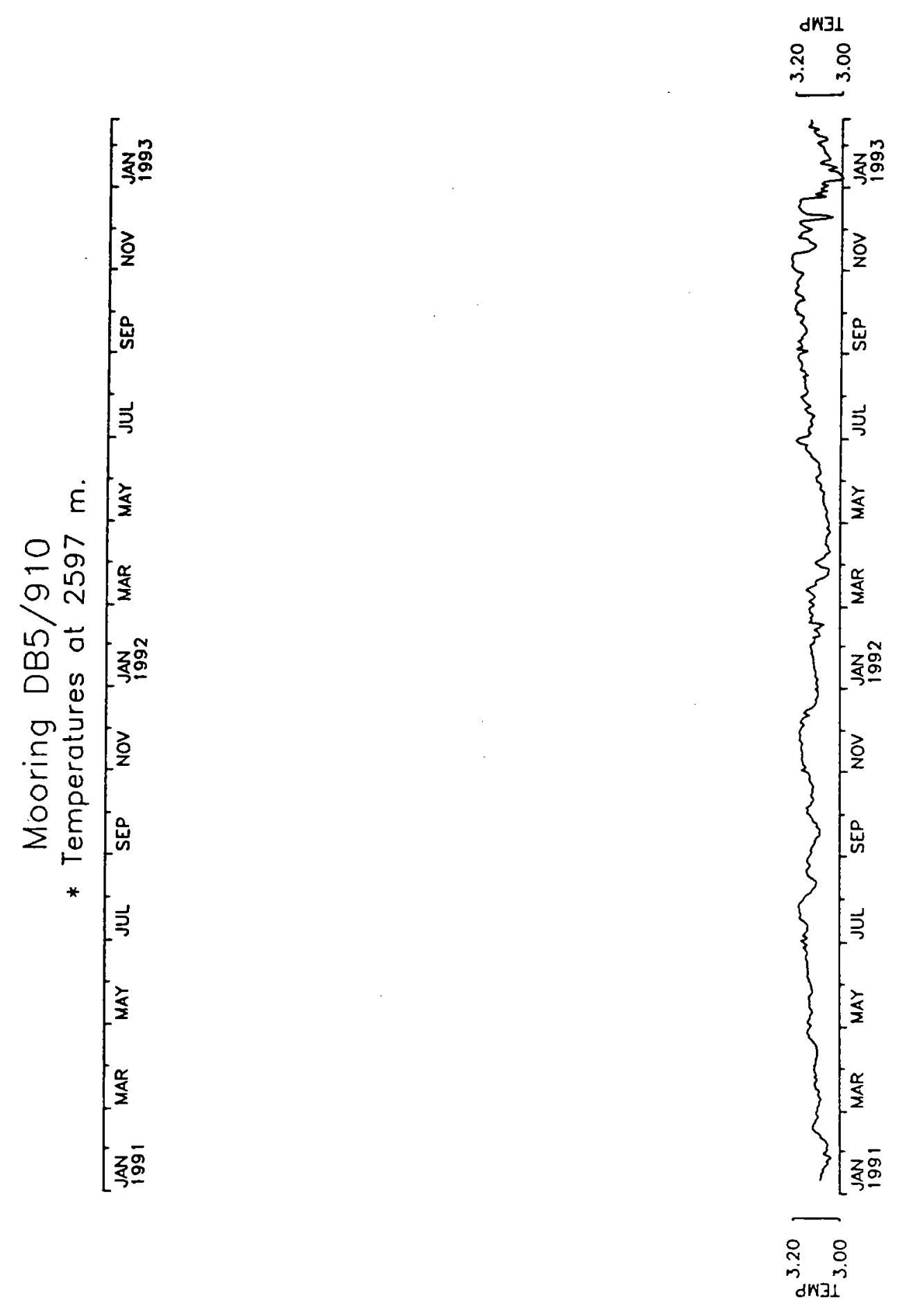




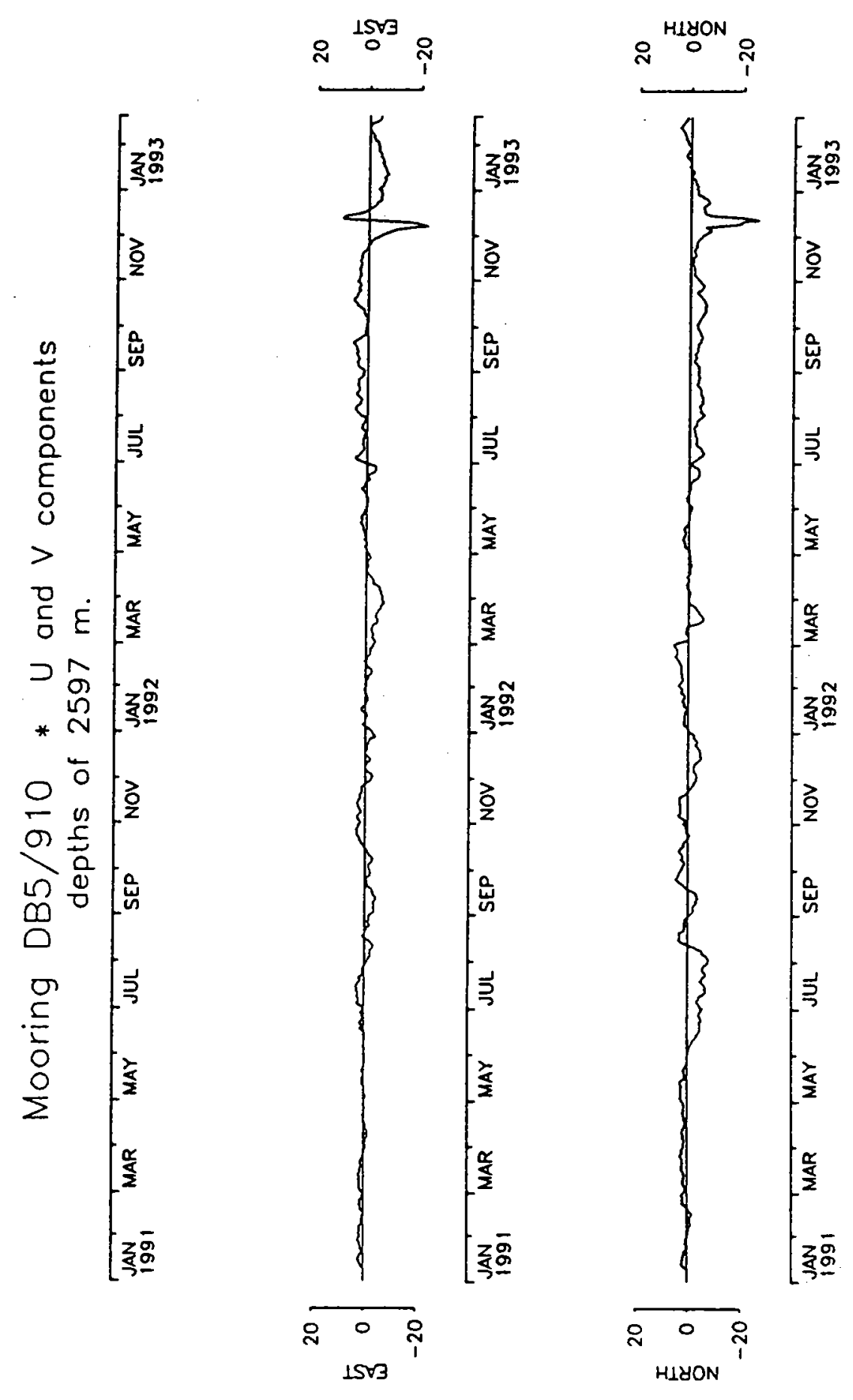



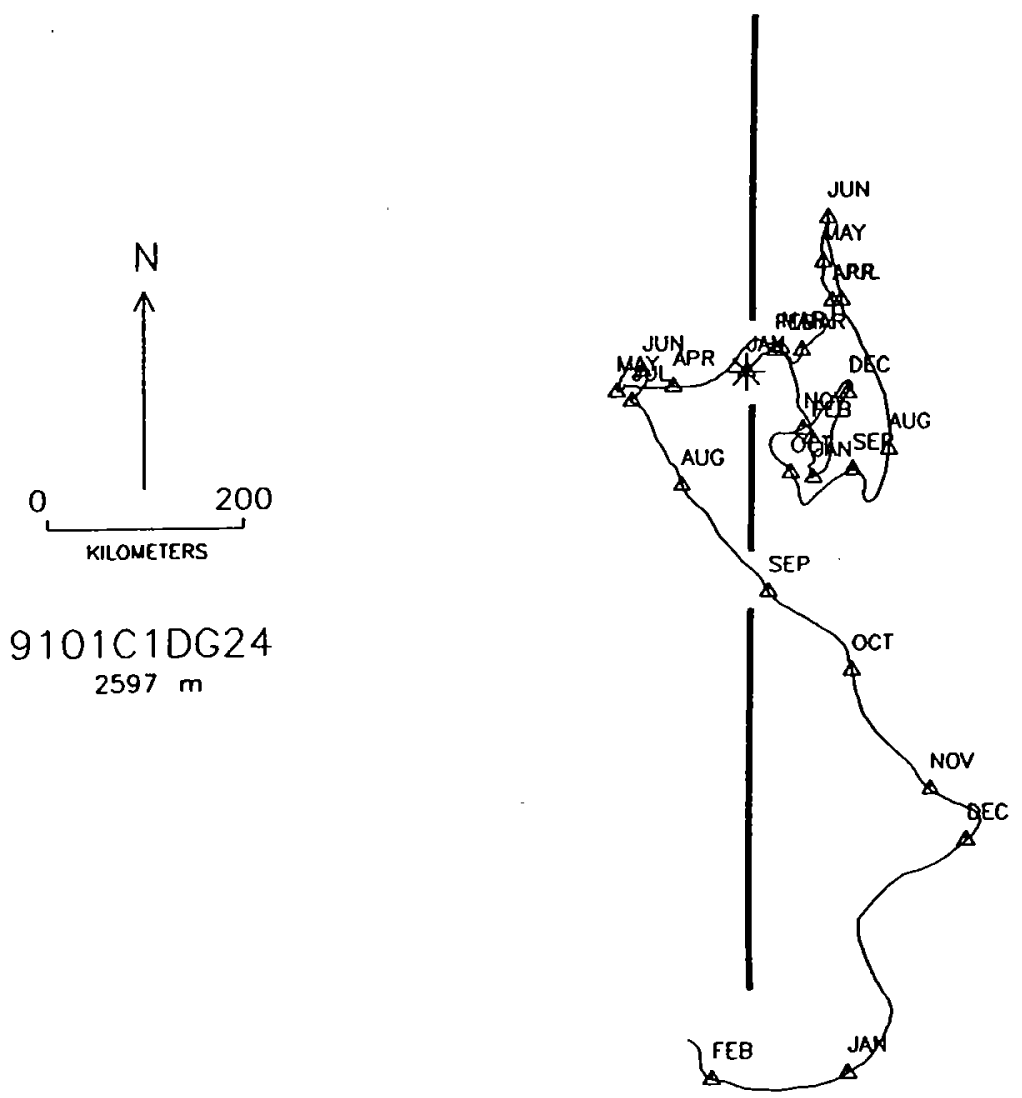


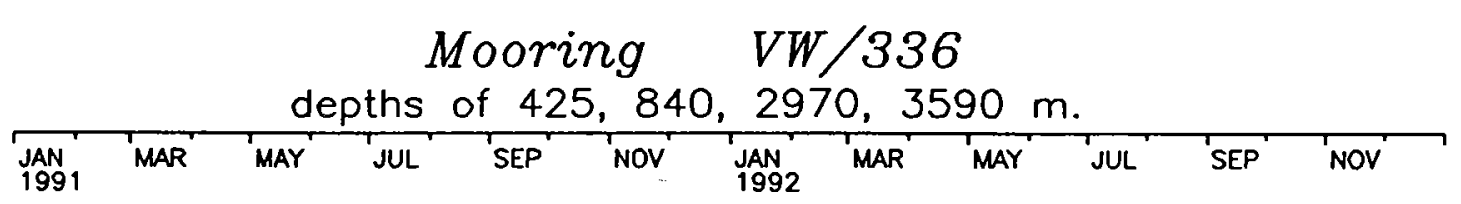
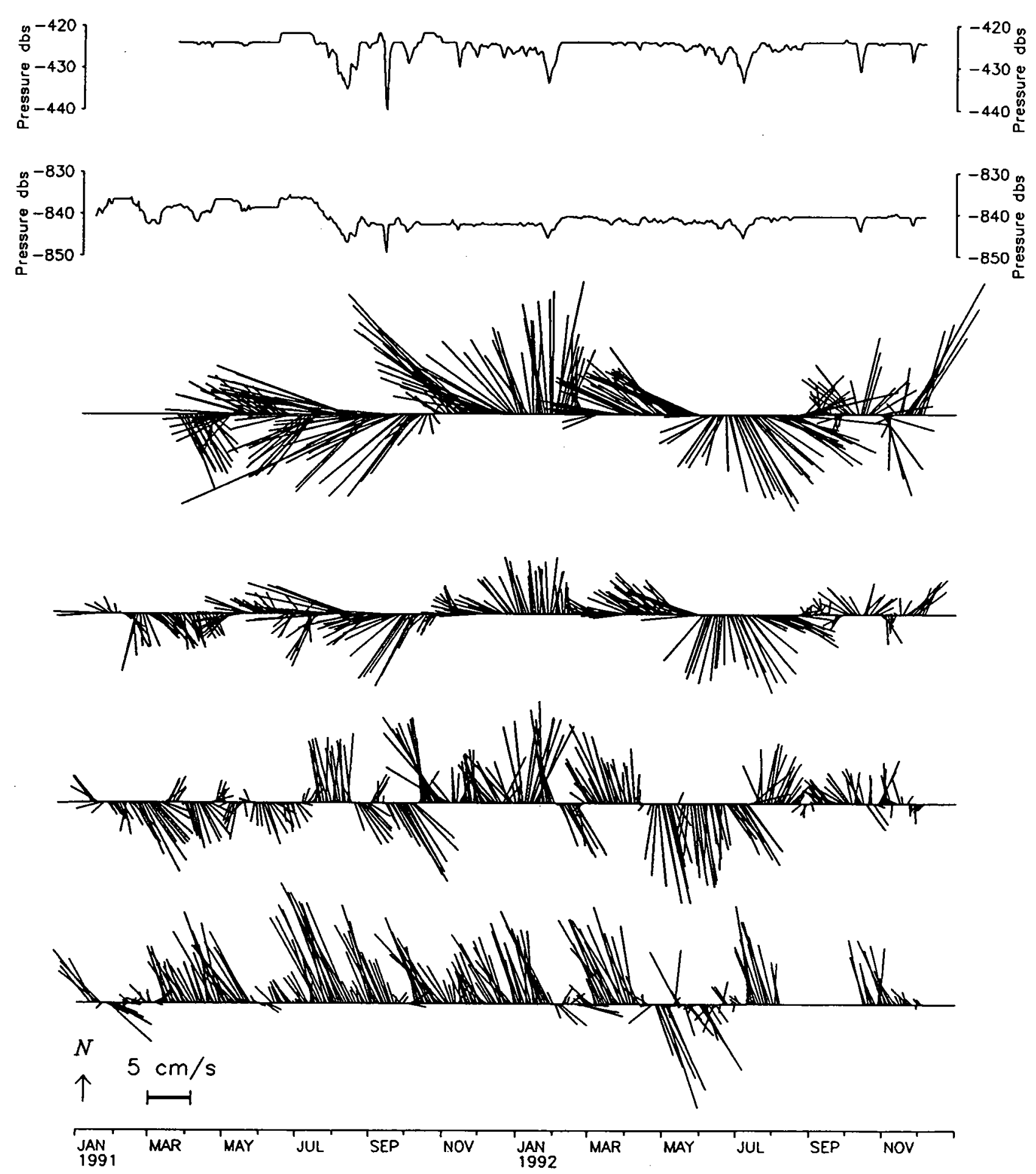
Mooring VW/336

* Temperatures at $425,840,2970,3590$ meters

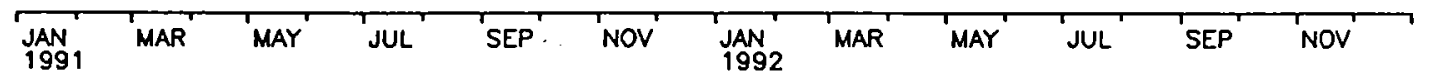

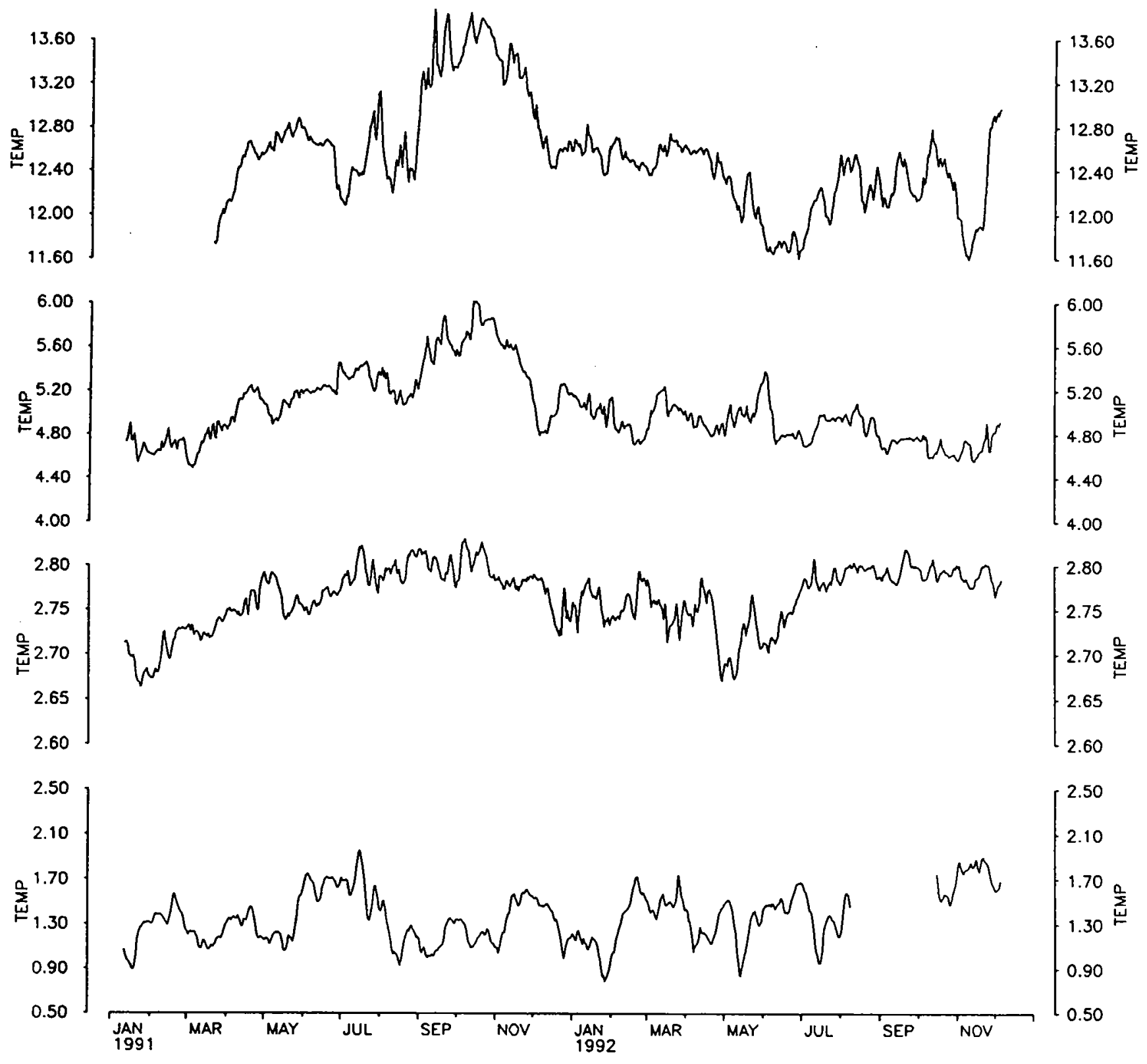


Mooring VW/336 * U and $V$ components depths of $425,840,2970,3590 \mathrm{~m}$.
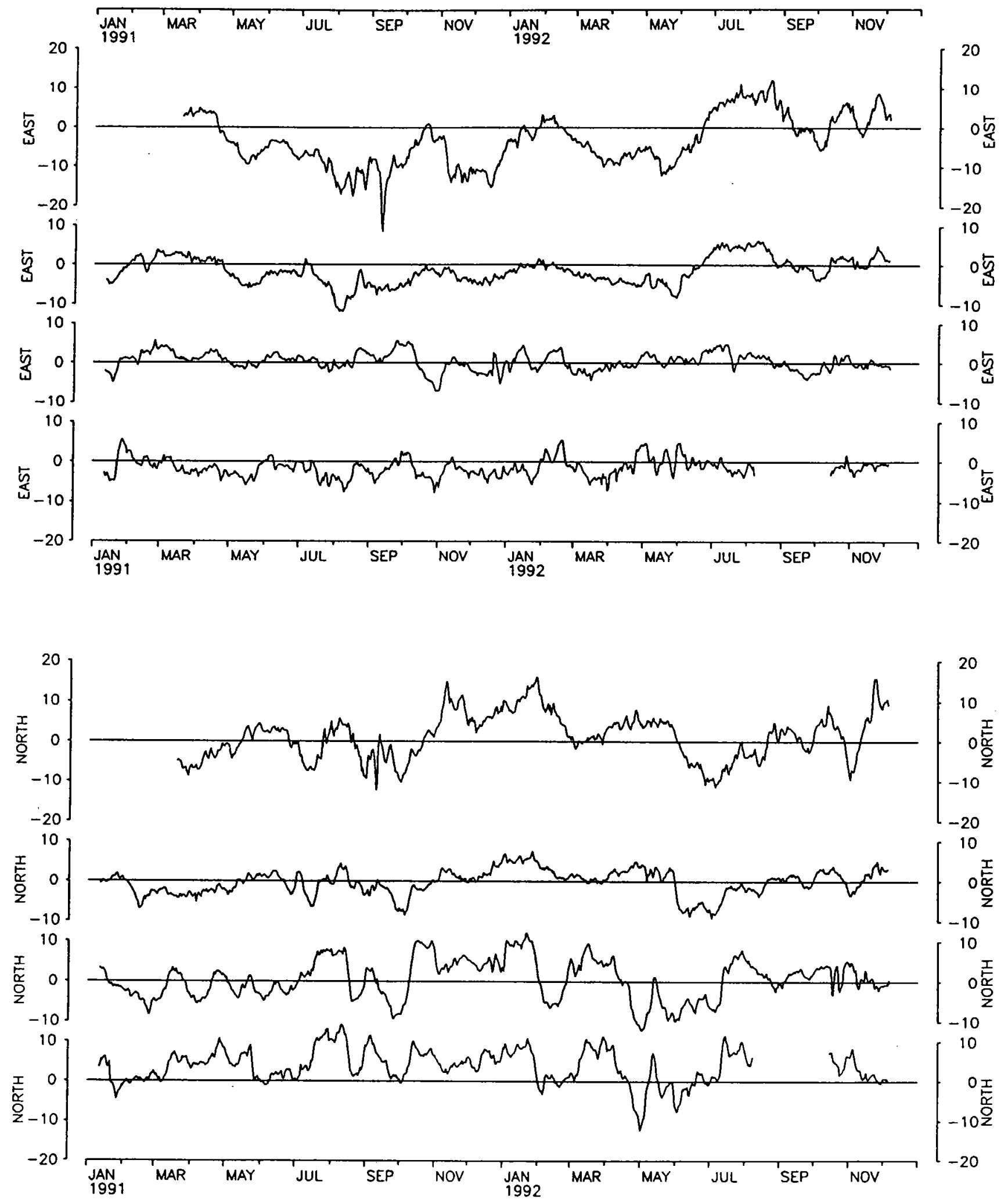


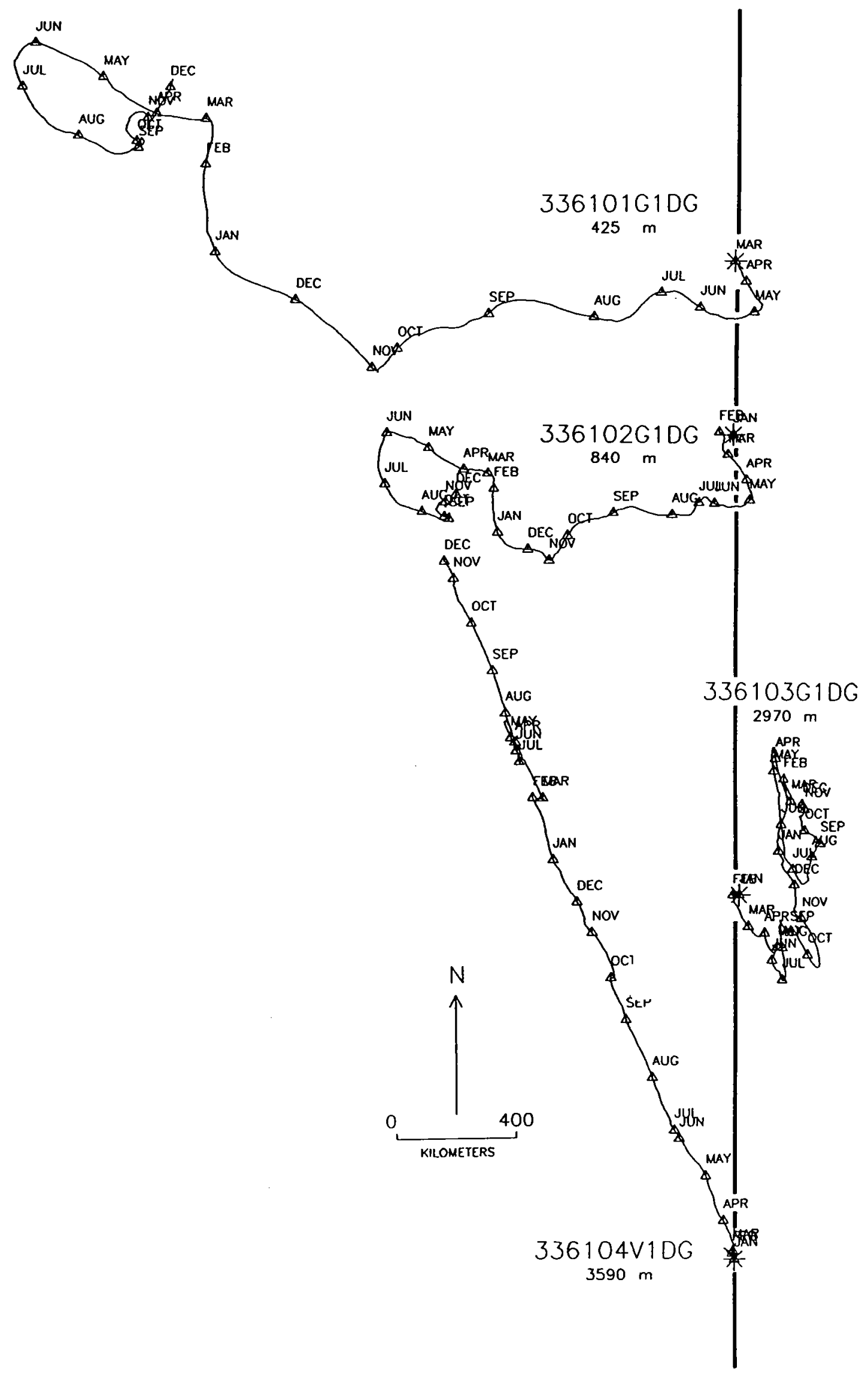



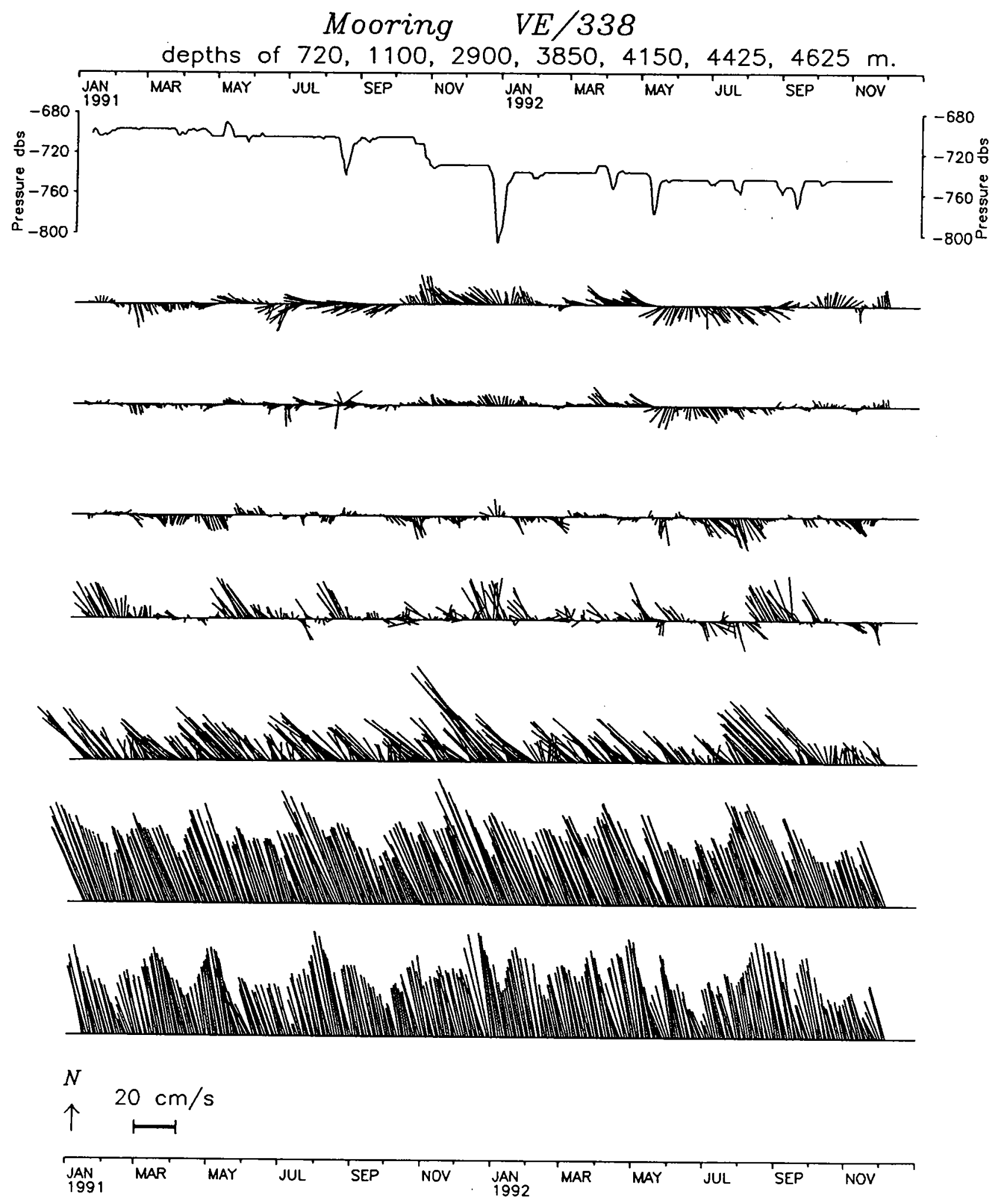
* Temperatures at $720,1100,2900,3850,4150,4425,4625$ meters

JAN, MAR 'MAY JUL 'SEP 'NOV JAN' MAR 'MAY' JUL ' SEP' NOV'

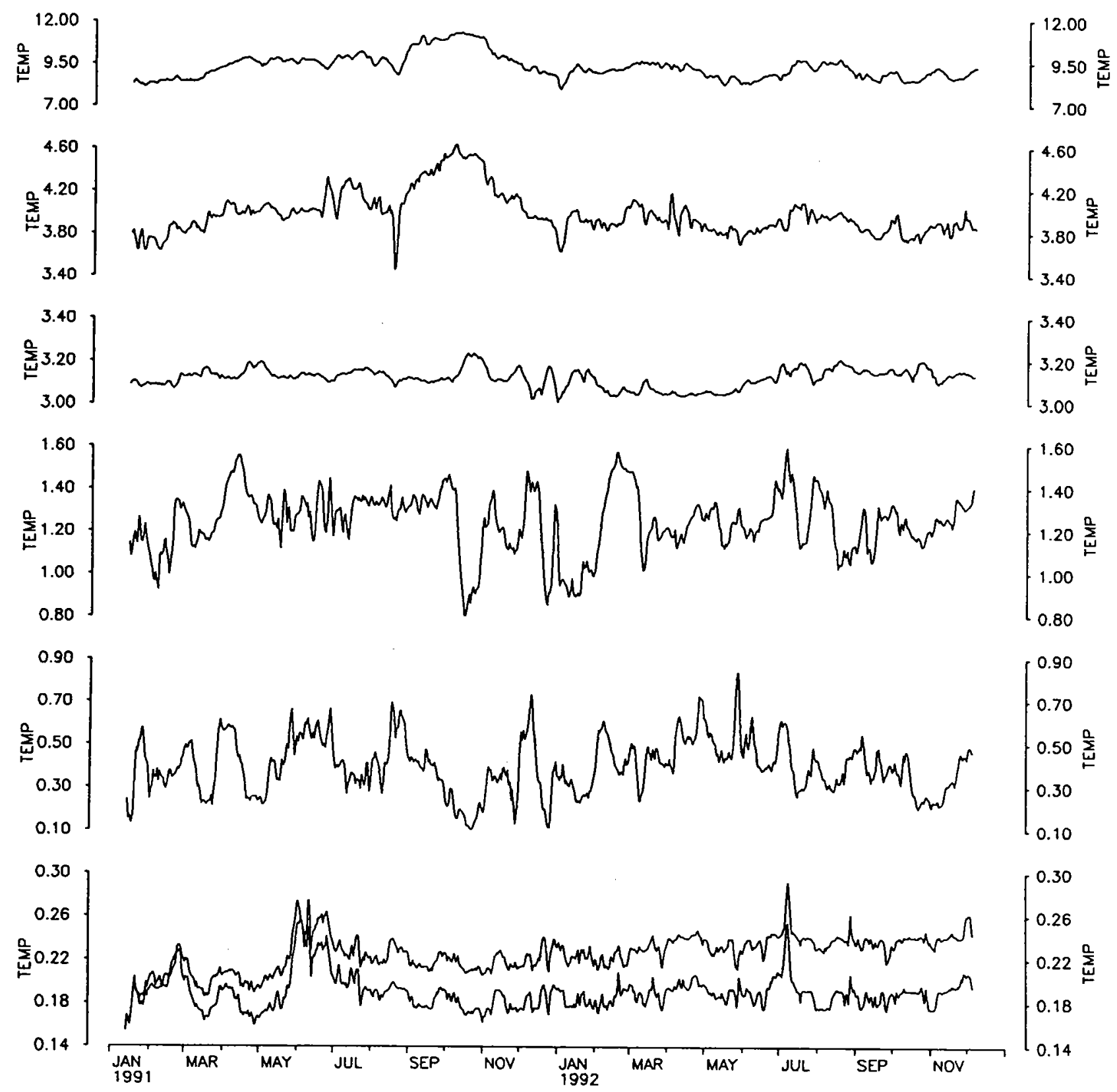




\section{Mooring $\mathrm{VE} / 338 * U$ and $\mathrm{V}$ components}

depths of $720,1100,2900,3850,4150,4425,4625 \mathrm{M}$.

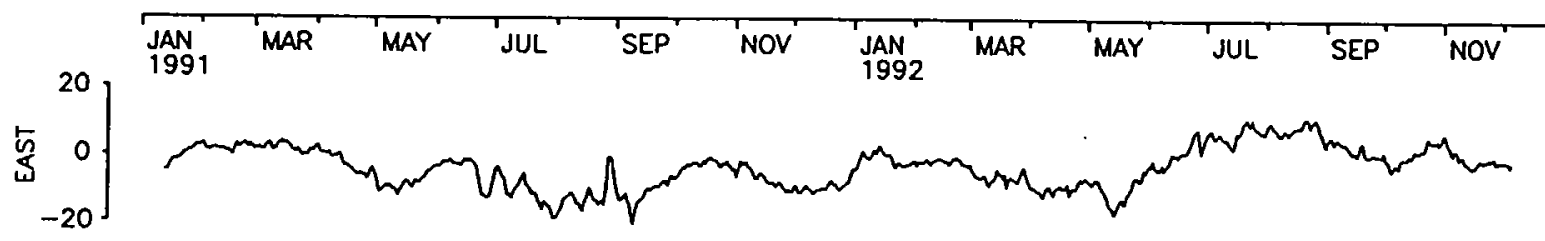

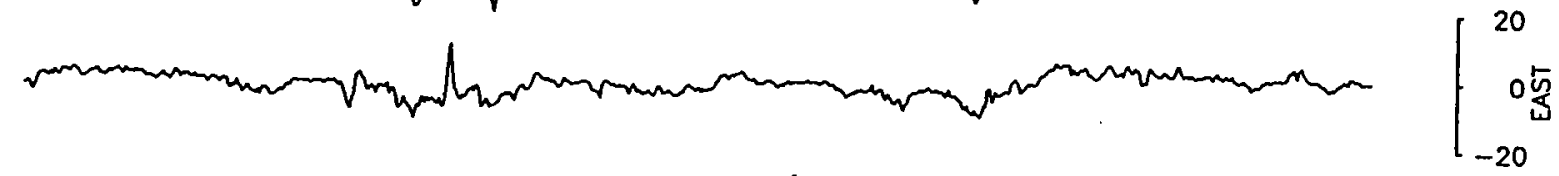

$\left.\sum_{-20}^{20} 0\right]$

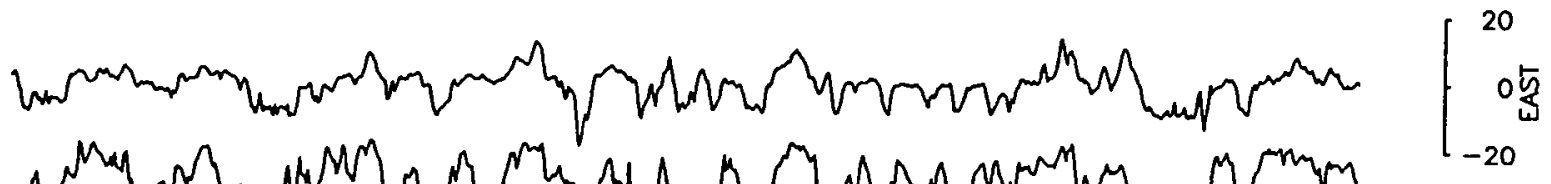

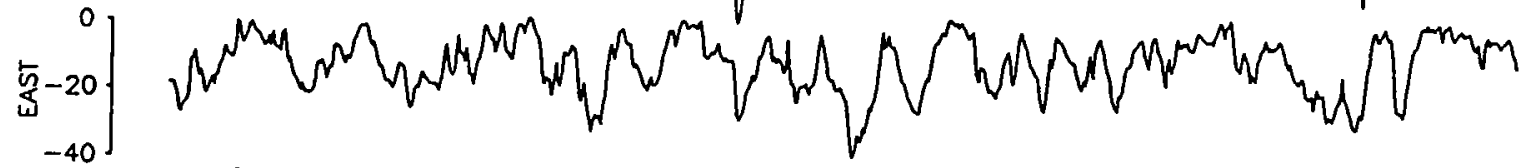

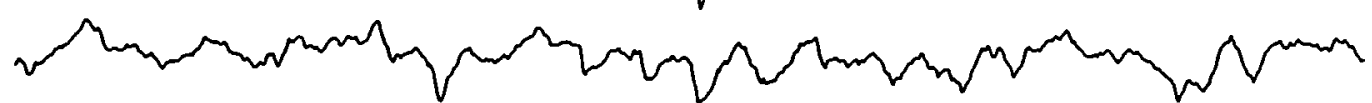

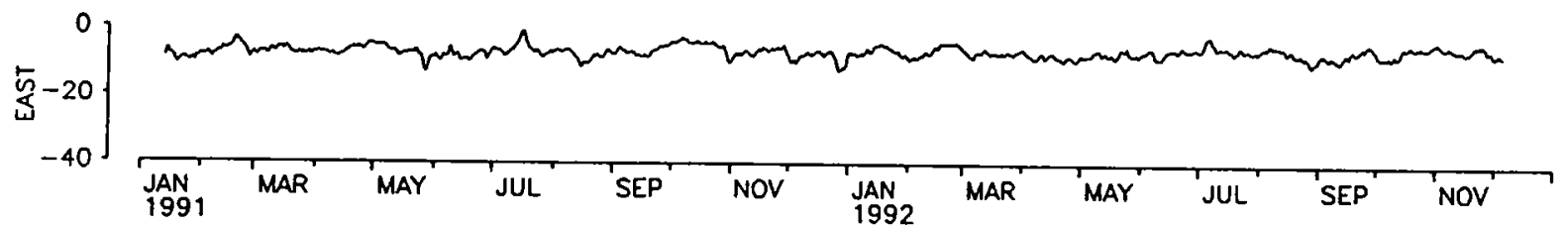

$\left[\begin{array}{c}0 \\ -20 \frac{\cos }{\mathbf{w}} \\ -40\end{array}\right.$

]$_{-20}^{20}$

$\int_{-20}^{20} \int_{\frac{1}{2}}^{20}$

]$_{-20}^{20}$

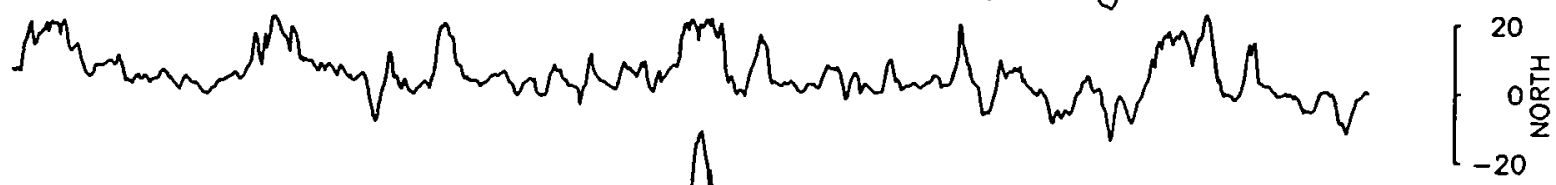

${ }_{0}^{40}$

$\int_{\substack{\text { JAN } \\ \text { 1991 }}}^{\sum_{\text {MAR }}^{20}} \underbrace{}_{\text {MAY }}$ 


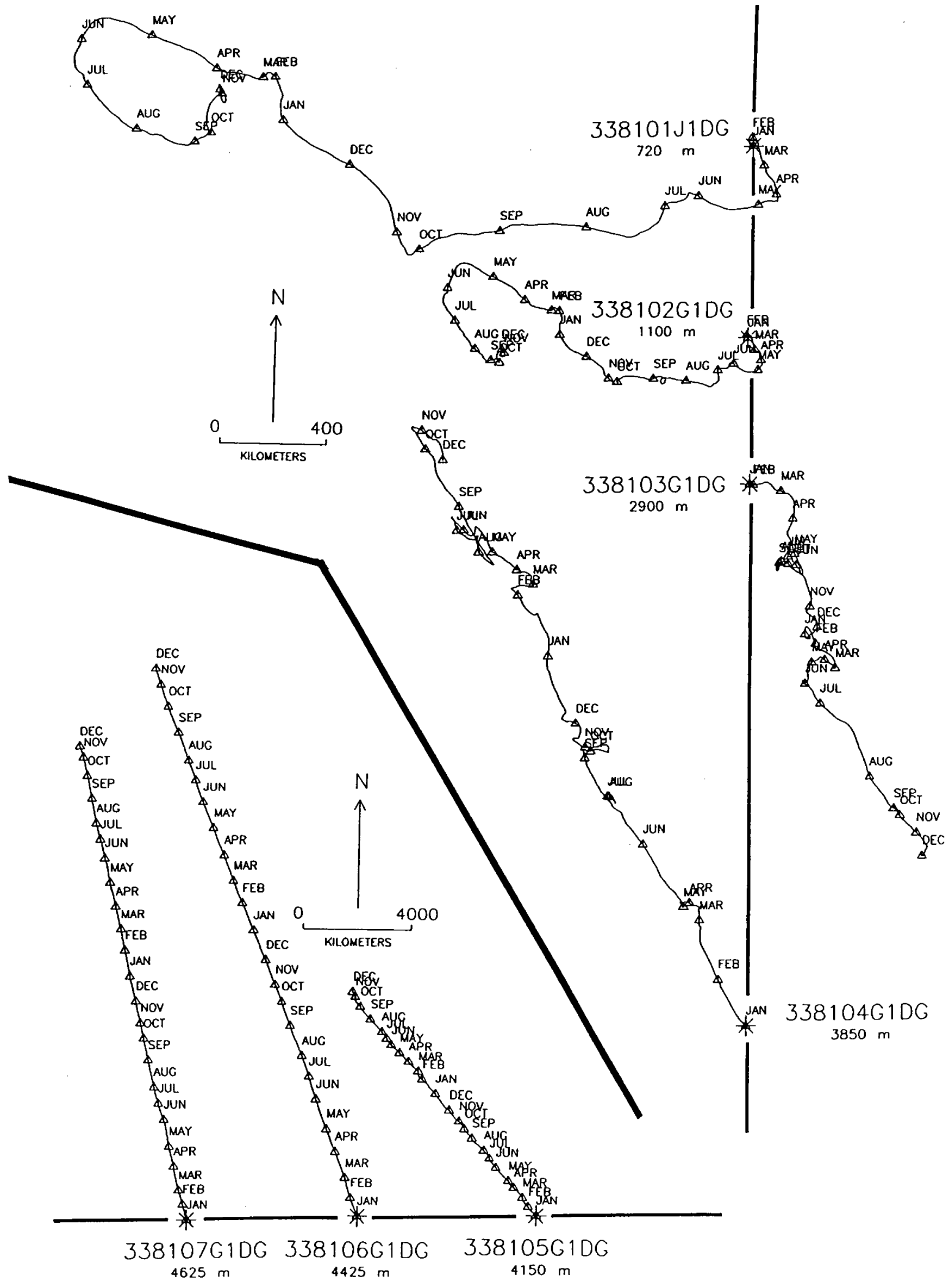




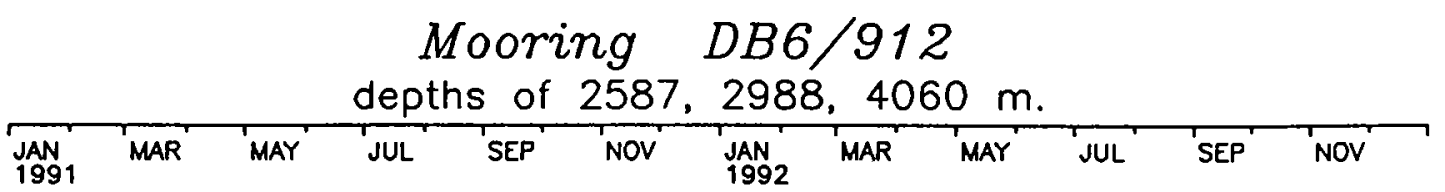
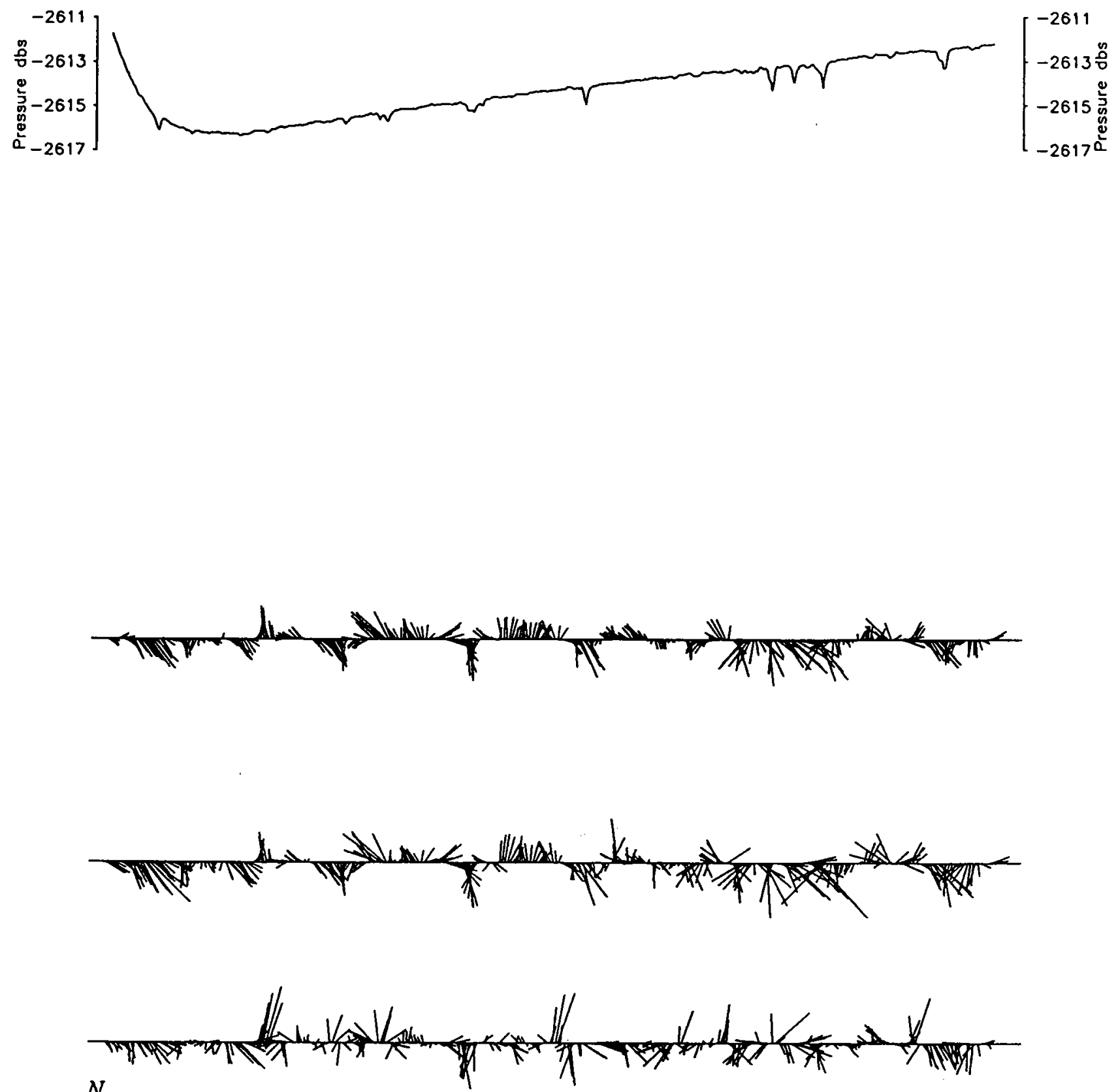
$N$

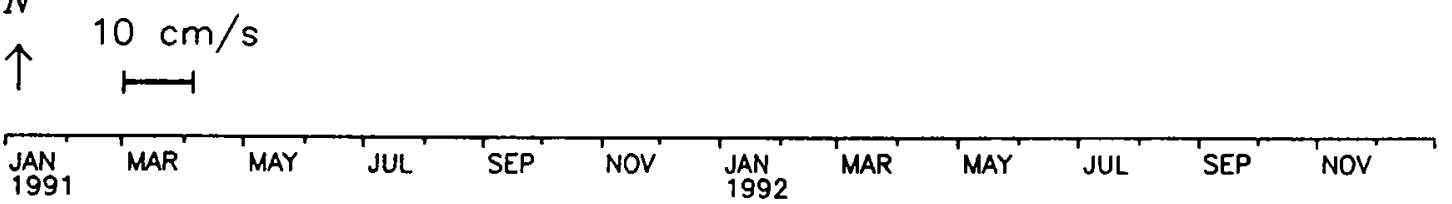


Mooring DB6/912

* Temperatures at $2587,2988,4060 \mathrm{M}$.

JAN MAR MAY JUL 'SEP NOV JAN
1991 MAR MAY JUL SEP NOV

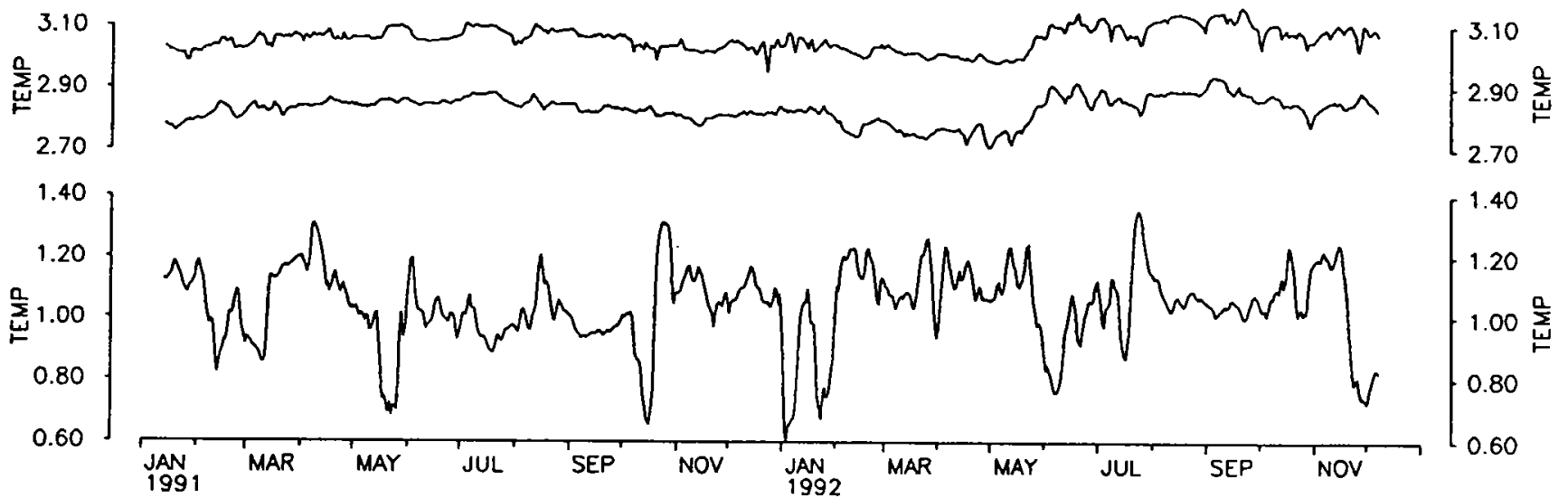


Mooring DB6/912*U and $V$ components depths of $2578,2988,4060 \mathrm{~m}$.

JAN' MAR MAY JUL SEP 'NOV' JAN 'MAR MAY JUL SEP NOV'
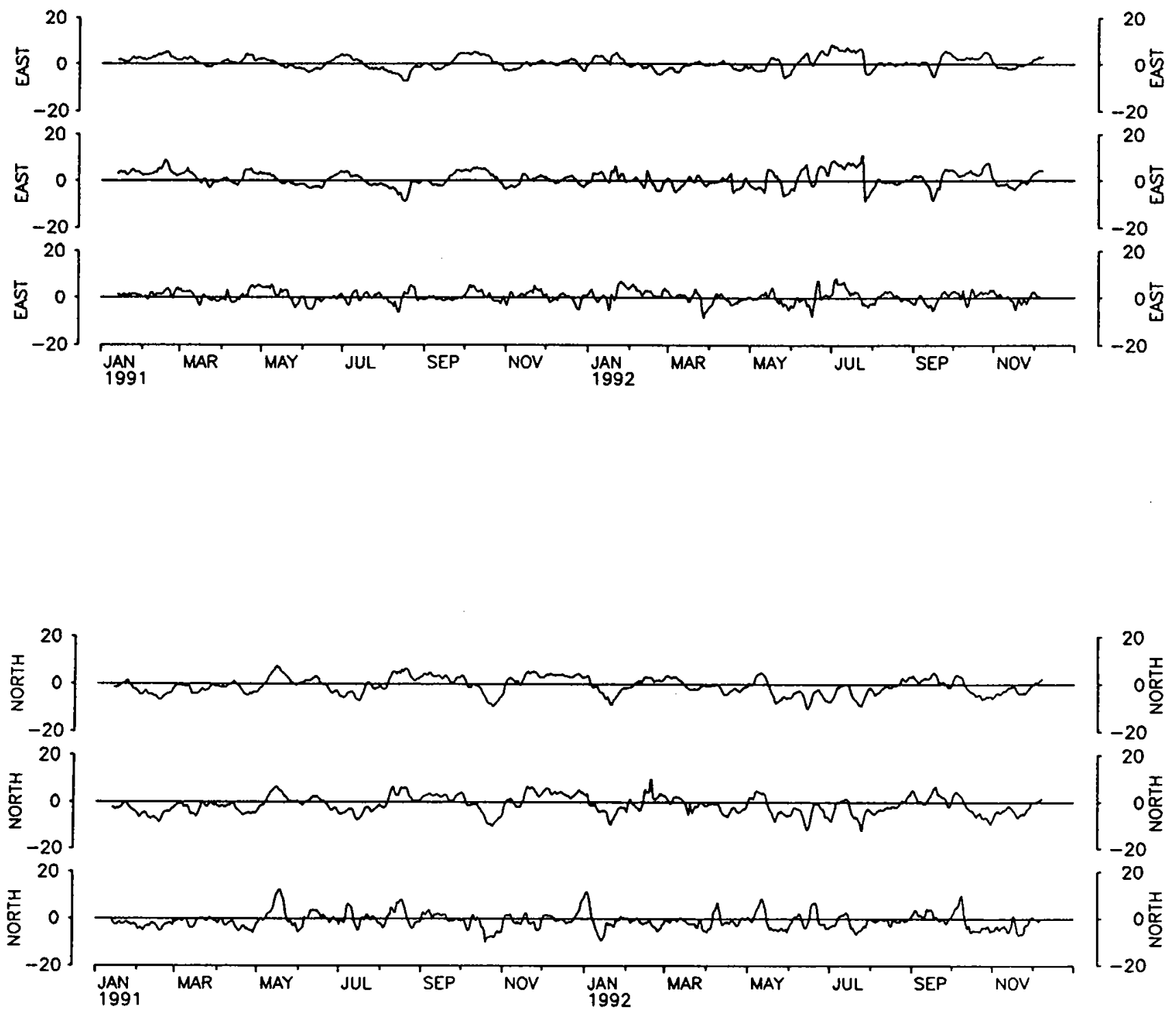


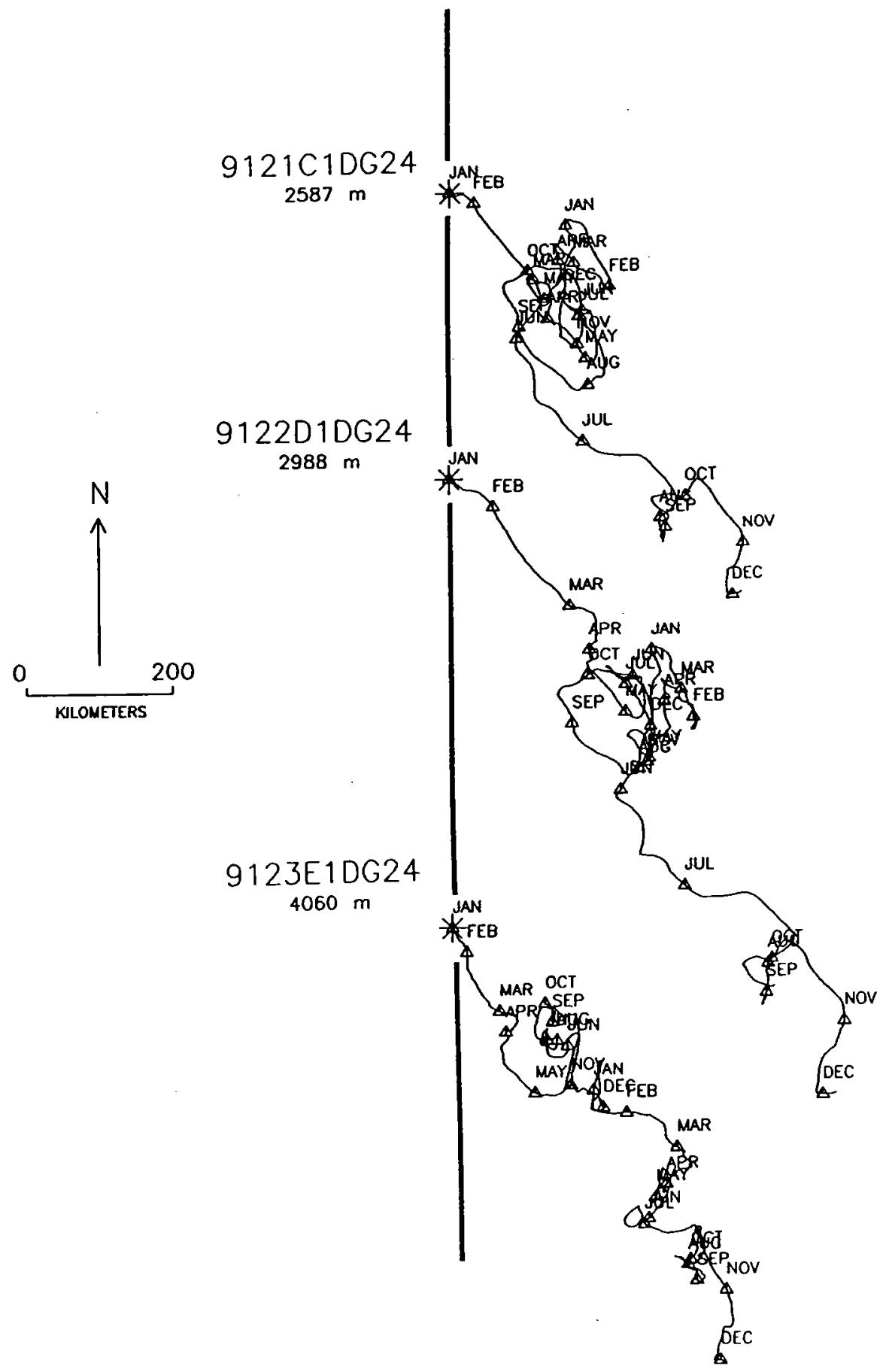




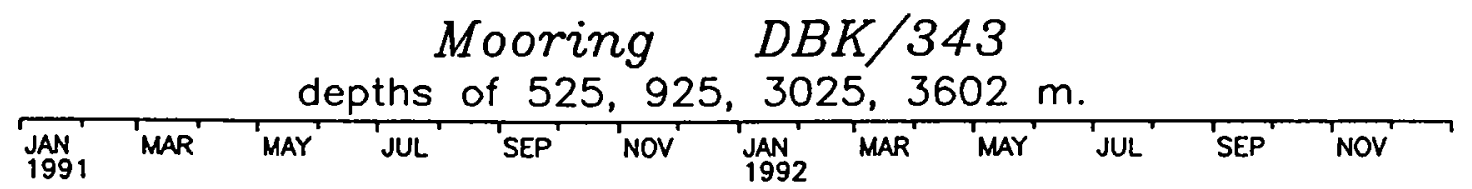
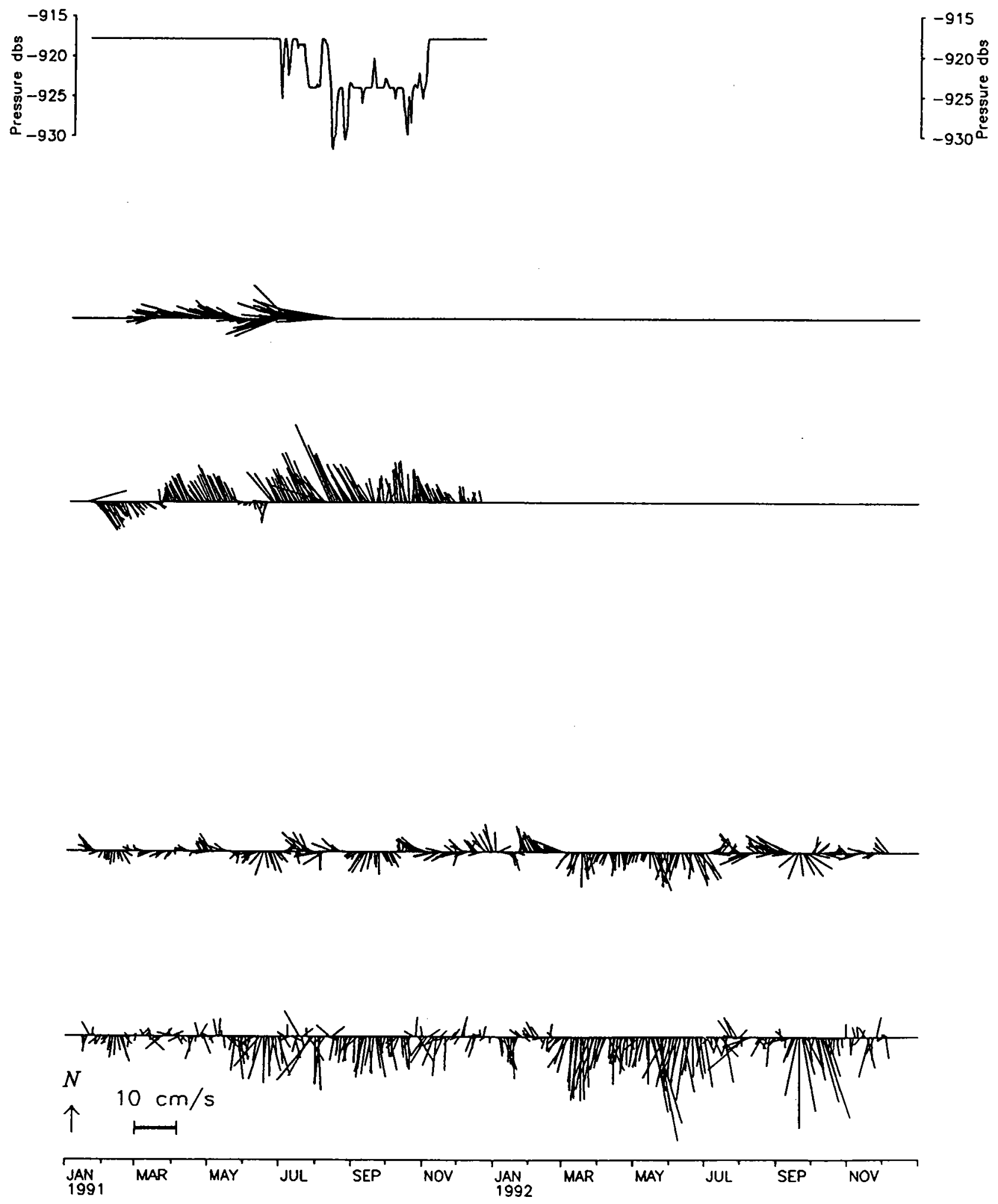
Mooring DBK/343

* Temperatures at 525, 925, 3025, 3602 meters

JAN MAR MAY JUL SEP NOV JAN ' MAR MAY JUL 'SEP NOV '
1991

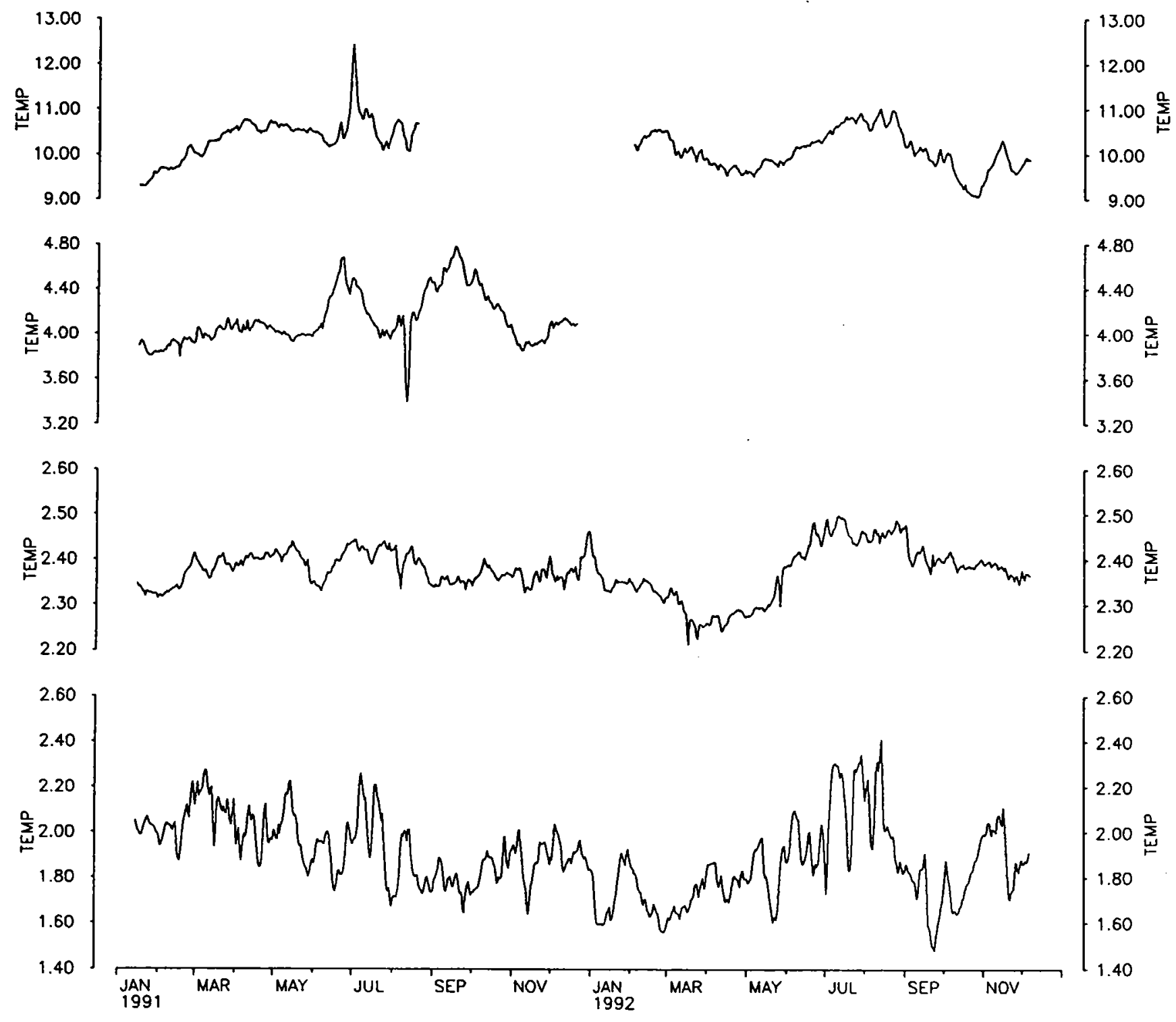




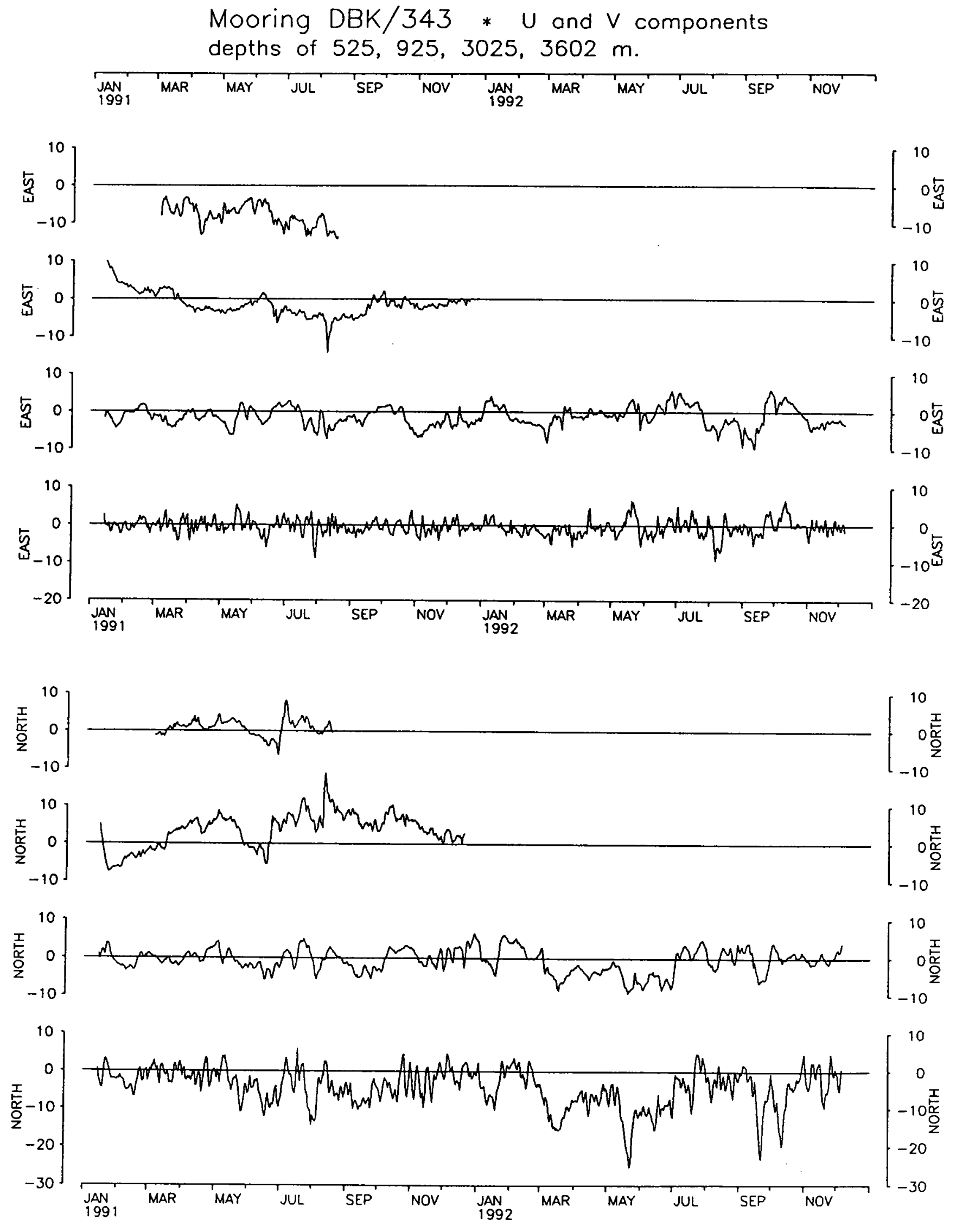




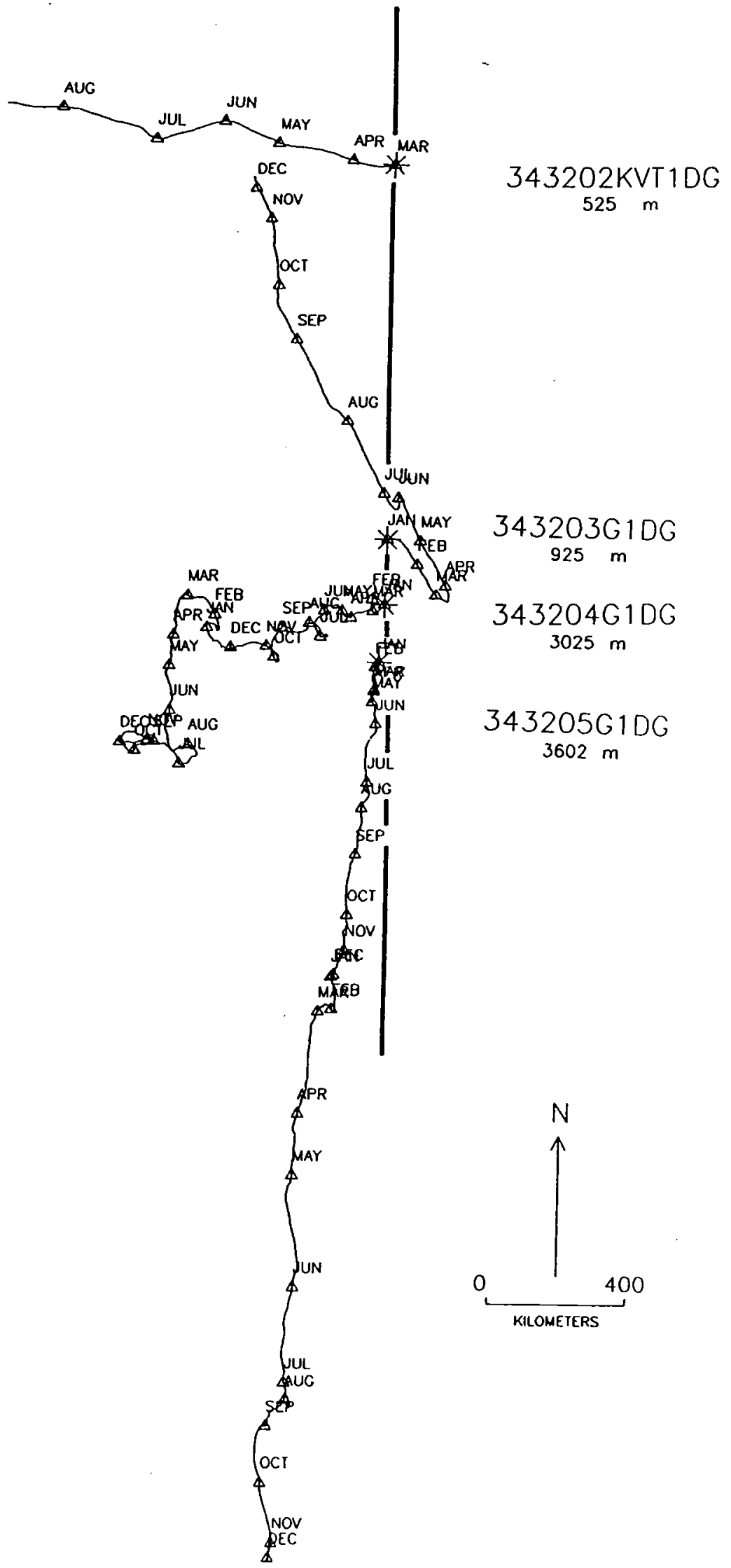




\section{DOCUMENT LIBRARY}

University of California, San Diego

SIO Library $0175 \mathrm{C}$ (TRC)

9500 Gilman Drive

La Jolla, CA 92093-0175

Hancock Library of Biology \& Oceanography

Alan Hancock Laboratory

University of Southern California

University Park

Los Angeles, CA 90089-0371

Gifts \& Exchanges

Library

Bedford Institute of Oceanography

P.O. Box 1006

Dartmouth, NS, B2Y 4A2, CANADA

Commander

International Ice Patrol

1082 Shennecossett Road

Groton, CT 06340-6095

NOAA/EDIS Miami Library Center

4301 Rickenbacker Causeway

Miami, FL 33149

Library

Skidaway Institute of Oceanography

10 Ocean Science Circle

Savannah, GA 31411

Institute of Geophysics

University of Hawaii

Library Room 252

2525 Correa Road

Honolulu, HI 96822

Marine Resources Information Center

Building E38-320

MIT

Cambridge, MA 02139

Library

Lamont-Doherty Geological Observatory

Columbia University

Palisades, NY 10964

Library

Serials Department

Oregon State University

Corvallis, OR 97331

Pell Marine Science Library

University of Rhode Island

Narragansett Bay Campus

Narragansett, RI 02882
Working Collection

Texas A\&M University

Dept. of Oceanography

College Station, TX 77843

Fisheries-Oceanography Library

151 Oceanography Teaching Bldg.

University of Washington

Seattle, WA 98195

Library

R.S.M.A.S.

University of Miami

4600 Rickenbacker Causeway

Miami, FL 33149

Maury Oceanographic Library

Naval Oceanographic Office

Building 1003 South

1002 Balch Blvd.

Stennis Space Center, MS 39522-5001

Library

Institute of Ocean Sciences

P.O. Box 6000

Sidney, B.C. V8L 4B2

CANADA

Library

Institute of Oceanographic Sciences

Deacon Laboratory

Wormley, Godalming

Surrey GU8 5UB

UNITED KINGDOM

The Librarian

CSIRO Marine Laboratories

G.P.O. Box 1538

Hobart, Tasmania

AUSTRALIA 7001

Library

Proudman Oceanographic Laboratory

Bidston Observatory

Birkenhead

Merseyside L43 7 RA

UNITED KINGDOM

IFREMER

Centre de Brest

Service Documentation - Publications

BP 7029280 PLOUZANE

FRANCE 


\begin{tabular}{|c|c|c|}
\hline $\begin{array}{c}\text { REPORT DOCUMENTATION } \\
\text { PAGE }\end{array}$ & 1. REPORT NO. WHOI-94-07 & 3. Recipient's Accession No. \\
\hline \multirow{2}{*}{\multicolumn{2}{|c|}{$\begin{array}{l}\text { 4. Title and Subtitle } \\
\text { A moored array along the southern boundary of the Brazil Basin for the Deep } \\
\text { Basin Experiment-Report on a joint experiment 1991-1992. }\end{array}$}} & $\begin{array}{l}\text { 5. Report Date } \\
\text { February } 1994\end{array}$ \\
\hline & & 6 \\
\hline \multicolumn{2}{|c|}{ Susan Tarbell, Ralf Meyer, Nelson Hogg, and Walter Zenk } & $\begin{array}{l}\text { 8. Performing Organization Rept. No. } \\
\text { WHOI-94-07 }\end{array}$ \\
\hline \multirow{2}{*}{\multicolumn{2}{|c|}{$\begin{array}{l}\text { 9. Performing Organization Name and Address } \\
\text { Woods Hole Oceanographic Institution } \\
\text { Woods Hole, Massachusetts } 02543\end{array}$}} & 10. Project/Task/Work Unit No. \\
\hline & & $\begin{array}{l}\text { 11. Contract(C) or Grant(G) No. } \\
\text { (C) OCE } 9004396 \\
\text { (G) }\end{array}$ \\
\hline \multirow{2}{*}{\multicolumn{2}{|c|}{$\begin{array}{l}\text { 12. Sponsoring Organization Name and Address } \\
\text { National Science Foundation }\end{array}$}} & $\begin{array}{l}\text { 13. Type of Report \& Period Covered } \\
\text { Technical Report }\end{array}$ \\
\hline & & 14. \\
\hline
\end{tabular}

This report should be cited as: Woods Hole Oceanog. Inst. Tech. Rept., WHOI-94-07.

16. Abstract (Limit: 200 words)

The Deep Basin Experiment (DBE) is an international effort and a part of the World Ocean Circulation Experiment with the principal objective of improving our knowledge of the subthermocline circulation. The DBE fieldwork is focussed on the Brazil Basin and this report is concerned with a moored array situated along its southern boundary which was installed in early 1991 to measure the inflow and outflow to the Basin and to investigate the Brazil Current near 30S. This moored array was a joint undertaking by the Institut für Meereskunde of the University of Kiel and the Woods Hole Oceanographic Institution. Moorings were deployed on Meteor Cruise 15, leg 1 and retrieved on Meteor cruise 22, legs 3 and 4. A total of 57 conventional current meters and two Acoustic Doppler Current Profilers were set on 13 moorings with some concentration within the Brazil Current and the Vema Channel. CTDs were taken at each mooring site as well as in between. Some of the recovered instruments were reset in the Hunter Channel, a suspected additional connection between the Argentine Basin and the Brazil Basin. A later report will summarize this data after it is recovered in May 1994.

17. Document Analysis a. Descriptors

WOCE

Deep Basin Experiment

ocean currents

b. Identifiers/Open-Ended Terms

c. COSATI Field/Group

18. Availability Statement

Approved for public release; distribution unlimited.

19. Security Class (This Report)

UNCLASSIFIED

20. Security Class (This Page)
21. No. of Pages

107 